Universidade de São Paulo

Fabiele Aparecida Trujillo da Silva

\title{
ROUSSEAU E A EDUCAÇÃO DO ADOLESCENTE PARA CIDADANIA - CONTRAPONTOS COM A ATUALIDADE
}

São Paulo 2008 
Fabiele Aparecida Trujillo da Silva

\section{ROUSSEAU E A EDUCAÇÃO DO ADOLESCENTE PARA CIDADANIA - CONTRAPONTOS COM A ATUALIDADE}

Dissertação desenvolvida sob orientação da Prof $^{a}$. Maria de Fátima Simões Francisco e apresentada ao Programa de Pós-graduação da Faculdade de Educação, área de Filosofia e Educação, da Universidade de São Paulo, como requisito para a obtenção do título de Mestre em Educação.

\section{São Paulo}


Autorizo a reprodução e divulgação total ou parcial deste trabalho, por qualquer meio convencional ou eletrônico, para fins de estudo e pesquisa, desde que citada a fonte.

Catalogação na Publicação

Serviço de Biblioteca e Documentação

Faculdade de Educação da Universidade de São Paulo

37.01

S586r
Silva, Fabiele Aparecida Trujillo da

Rousseau e a educação do adolescente para cidadania Contrapontos com a atualidade / Fabiele Aparecida Trujillo da Silva; orientação Maria de Fátima Simões Francisco. São Paulo: s.n., 2008.

$109 \mathrm{p}$.

Dissertação (Mestrado - Programa de Pós-Graduação em Educação. Área de Concentração: Filosofia e Educação) Faculdade de Educação da Universidade de São Paulo.

1. Rousseau, Jean-Jacques 2. Educação para cidadania 3. Educação - Filosofia 4. Política 5. Adolescência I. Francisco, 


\section{Fabiele Aparecida Trujillo da Silva}

RousSeau E A EdUCAÇÃo do AdOLESCENTE PARA CIDADANIA - CONTRAPONTOS COM A ATUALIDADE

Aprovado em:

Dissertação desenvolvida sob orientação da Prof ${ }^{\text {a }}$ Maria de Fátima Simões Francisco e apresentada ao Programa de Pós-graduação da Faculdade de Educação, área de Filosofia e Educação, da Universidade de São Paulo como requisito para a obtenção do título de Mestre em Educação.

Banca Examinadora

$\operatorname{Prof}(a) \cdot \operatorname{Dr}(a) .:$

Instituição: Assinatura:

Prof(a). Dr(a).:

Instituição: Assinatura:

$\operatorname{Prof(a).~Dr(a).:~}$

Instituição: Assinatura: 


\section{Dedicatória}

A meus pais, com amor, carinho e gratidão, por toda força e apoio ao longo de todos os momentos da minha vida. 
Agradecimentos

A Deus, por absolutamente tudo.

Ao Sr. Claude e D. Lourdes, pelo norte em todos momentos de vendaval.

Aos meus avós, por terem existido de uma maneira tão singela em minha vida.

Ao meu querido Joaquim, pela paciência e pelo companheirismo.

À minha orientadora, Prof ${ }^{\mathrm{a}}$. Dr ${ }^{\mathrm{a}}$. Fátima, por propiciar um encontro tão agradável com Rousseau.

À Faculdade de Educação da Universidade de São Paulo, pela oportunidade de realização do curso de Mestrado.

À querida amiga Margarida, pelo apoio e estímulo, além das leituras em busca de deslizes. 
"O homem é muito forte quando se contenta em ser o que é, e é muito fraco quando deseja erguer-se acima da humanidade".

Rousseau

"Cidadania é participação, é ter direitos e obrigações, e, ao contrário do que muitos pensam, se aprende na escola".

Jaime Pinsky 


\section{RESUMO}

SILVA, F. A. T. Rousseau e a educação do adolescente para a cidadania. 2008. 109 f. Dissertação (Mestrado) - Faculdade de Educação, Universidade de São Paulo, São Paulo, 2008.

Atualmente, a educação brasileira enfrenta um período de crise, seja pelas condições de trabalho dos educadores, pela insuficiência dos recursos financeiros destinados, pela ausência da família, pela falta de recursos didáticos ou pela má formação dos professores, entre inúmeros fatores. E um dos objetivos mais perseguidos, até mesmo para tentar, num futuro próximo, superar essa crise, é a definição acerca do conceito e de como realizar a educação para cidadania. Muitos educadores, inclusive aqueles que elaboram os documentos que são referenciais na educação do país, como os PCNs (Parâmetros Curriculares Nacionais), apontam para a idéia de que é possível melhorar a situação brasileira se houver uma educação voltada para a formação do cidadão. Em contrapartida, no ambiente escolar, pouco se discute ou se define sobre o que seja, de fato, a educação para a cidadania. Desse modo, é preciso que esse tema seja tratado com ênfase na definição do conceito de educação para cidadania, bem como no apontamento de princípios que norteiem para a realização efetiva dessa educação que forma o cidadão. A partir dessa preocupação, surgiu o tema da pesquisa, a educação do adolescente para a cidadania, que pretende apontar, dentro do contexto rousseauniano, o conceito de educação do homem e do cidadão, características da adolescência, princípios norteadores para a formação do adolescente voltada para a cidadania e contrapontos entre os ideais de Rousseau e a atualidade no que diz respeito à possibilidade de ter nos seus princípios um referencial para se pensar a educação para a cidadania dos jovens de hoje. Rousseau é o referencial teórico, devido à grandeza de suas obras no que diz respeito à política, como no Contrato Social e, especialmente, à educação, como no Emílio, lembrando que para o autor ambas são indissociáveis. Através da leitura dessas, entre outras obras do autor, principalmente do Emílio, seu Tratado de Educação, realizou-se uma análise em torno dos conceitos de educação doméstica, educação pública, educação negativa, formação do homem e do cidadão, para então, traçar o perfil do adolescente, levantando princípios que podem orientar sua formação para a cidadania. Especialmente com a leitura do Emílio, constatou-se que é possível formar o adolescente para a cidadania, o que se dá simultaneamente através da educação doméstica e da educação pública, que precisam ser 
norteadas pelos princípios, entre outros, de utilidade, necessidade e liberdade, propiciando ao educando uma postura crítica e reflexiva em torno da estrutura e do funcionamento da sociedade, e, assim, possibilitando-lhe uma vivência mais humana, participativa e democrática.

Palavras-chave: Rousseau, educação, política, cidadania e adolescência. 


\section{RÉSUMÉ}

SILVA, F. A. T. Rousseau et l'éducacion de l'adolescent pour la citoyenneté. 2008. 109 f. Dissertation (Monografhie) - Faculté de Educacion, Université de São Paulo, São Paulo, 2008.

Actuellement, l'éducation brésilienne affronte une période de crise laquelle, entre d'innombrables facteurs, provient des conditions de travail des éducateurs, de l'absence d'intérêt manifesté par la famille, de l'insuffisance de les recours financiers prédestinés, du manque de ressources didactiques ainsi que de la mauvaise formation des enseignants. Pour essayer, dans un avenir proche, de dépasser cette situation tendue, l'un des objectifs les plus poursuivis repose sur le concept et la pratique de l'éducation en fonction de la citoyenneté. Beaucoup d'éducateurs sont convaincus qu'il serait possible d'améliorer la situation brésilienne si l'éducation était dirigée vers la citoyenneté, en particulier ceux qui élaborent lês documents jugés comme étant des références en ce qui concerne l'enseignement dans notre pays, comme le PCNs (Paramètres des Curriculums Nationaux). En contrepartie, dans l'environnement scolaire, peu se discute ou se définit sur ce problème. De cette manière, il est nécessaire que ce thême soit traité attentivement dans la définition de l'éducation en relation à la citoyenneté, aussi bien que sur la remarque des principes qui dirigent la réalisation effective de cette éducation qui forme le citoyen. A partir de cette préoccupation, le besoin de la recherche de l'éducation de l'adolescent pour la citoyenneté est apparu. Ce thème prétend indiquer, dans le contexte de J.J. Rousseau, le concept de l'éducation de l'homme et du citoyen, les caractéristiques de l'adolescence, les principes qui orientent la formation de l'adolescent pour la citoyenneté et les contrepoints entre les idéaux de Rousseau avec l'actualité en ce qui concerne la possibilité de trouver dans ses principes des références pour penser à $1^{\prime}$ éducation pour la citoyenneté des jeunes d'aujourdhui.. Rousseau est le référentiel théorique, dû à la grandeur de ses oeuvres en ce qui concerne la politique, comme dans le Contrat Social et, surtout l'éducation, comme dans Emílio, rappelant que pour l'auteur toutes les deux sont indissociables. Au-travers de la lecture de ces deux livres, ainsi que d'autres oeuvres de cet auteur, principalement de l'Emílio, son Traité d'Éducation, une analyse a été réalisée en ce qui concerne les concepts d'éducation domestique, publique, négative, formation de l'homme et du citoyen, pour enfin, tracer le profil de l'adolescent, en mettant en évidence les principes qui peuvent guider leur formation pour la citoyenneté. La lecture d'Emílio, réhausse 
qu'il est possible de former l'adolescent pour la citoyenneté, car elle parvient simultanément au-travers de l'éducation domestique et de l'éducation publique, qui ont besoin d'être guidées par les principes, entre autres, ceux de l'utilité, de la nécessité et de la liberté, imprégnant l'éducateur d'un comportement critique, garni d'une réflexion adéquate en ce qui concerne la structure et le fonctionnement de la société, rendant ainsi possible une convivialité plus humaine, participative et démocratique.

Mots clefs: Rousseau, education, politique, citoyenneté et adolescence. 


\section{SUMÁRIO}

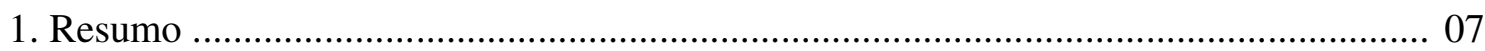

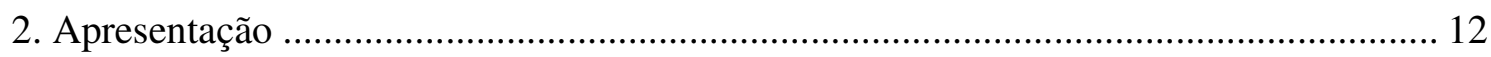

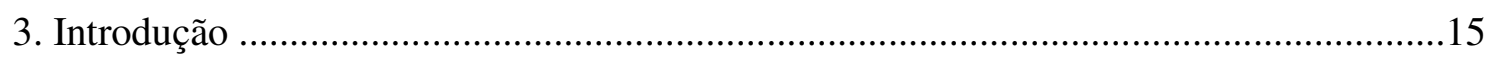

4. Capítulo I - Educação doméstica e educação pública ...................................................21

5. Capítulo II - Formar o homem é formar o cidadão ........................................................ 37

6. Capítulo III - O adolescente e a educação - Contrapontos entre Rousseau

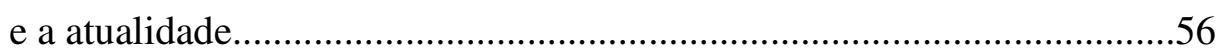

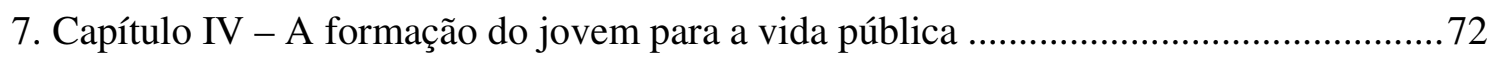

8. Capítulo V - Perspectivas para uma educação cidadã ..................................................... 93

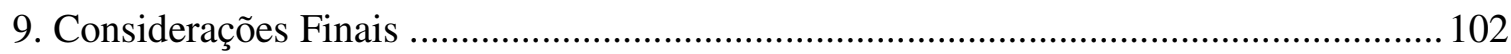

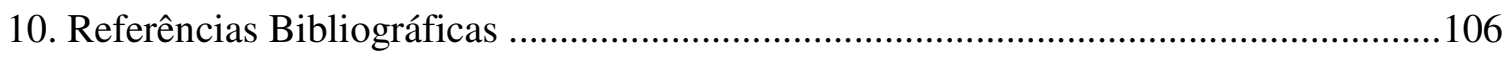




\section{APRESENTAÇÃO}

A educação é um tema pelo qual tenho interesse desde a adolescência, quando, ainda no interior de São Paulo, optei pelo curso de magistério, isto é, por ser professora. Durante esse período fiz estágios e trabalhei como auxiliar em Educação Infantil, nível no qual iniciei minha vida profissional.

Em seguida, resolvi cursar Filosofia, tendo grande expectativa quanto à licenciatura, já que a educação sempre foi o foco da minha formação. É interessante observar que quando ingressei no curso de Filosofia, as aulas desta disciplina no Ensino Médio eram escassas, posto que as escolas podiam optar por oferecê-las ou não, o que tornou minha escolha bastante estranha e incompreensível para muitos. Mas para mim que, desde o magistério, através de um contato superficial com alguns filósofos da educação, pude perceber esta paixão, foi a realização de um objetivo, de um ideal.

Durante a licenciatura tive a oportunidade de fazer Iniciação Científica, quando comecei as leituras sobre Rousseau, filósofo que hoje considero fundamental para qualquer área da educação. Tendo estudado a temática rousseauniana "Educação Doméstica ou Educação Pública: Formar o Homem ou o Cidadão?", pude iniciar uma análise do Emílio e a cada texto lido o tema despertou mais interesse, criando o desejo de aprofundamento nesta obra.

Neste espaço de tempo, em que não pude continuar lecionando devido à dedicação a graduação e à pesquisa de Iniciação Científica, não deixei de pensar na educação, realizando leituras sobre a área e visitando escolas, o que ampliou minhas reflexões sobre o tema e enriqueceu meu olhar, tornando-me mais sensível aos problemas enfrentados no cotidiano educacional e, assim, possibilitando uma percepção de que não é possível pesquisar educação sem vivenciar o ambiente escolar, sem estar em contato direto com professores, diretores, alunos, pais, enfim, com pessoas que, de fato, fazem a educação.

Logo que concluí a pesquisa, quando estava terminando a graduação - embora já tivesse o interesse por continuar pesquisando Rousseau - resolvi parar para vivenciar de fato o ambiente escolar, antes de decidir o tema para um possível projeto de mestrado, pois achei fundamental ter experiência na educação para então definir um objeto de pesquisa que estivesse presente no contexto educacional atual. 
A princípio trabalhei com Ensino Fundamental, já que tinha feito o curso de magistério, e depois, com Ensino Médio, lecionando Sociologia durante o primeiro ano e em seguida, de Filosofia, em escolas públicas e particulares, onde, através da vivência diária no ambiente escolar, pude perceber o quanto esse espaço é complexo e rico, o quanto proporciona em crescimento pessoal e profissional, pois a convivência com pessoas de realidades diversas faz com que reflitamos sobre os valores e princípios morais relevantes para o educador que pretende contribuir para formação humana e social do educando, o que evidenciou que o ambiente escolar é muito mais fecundo do que se pode imaginar quando se fala em educação.

Pude viver momentos em que a aula atendia às expectativas, mas também momentos de ansiedades, frustrações, medos e incertezas (como quando precisamos conviver com alunos indisciplinados, desrespeitosos ou, ainda, quando a própria realidade escolar nos impede de desenvolver aulas que sejam dinâmicas e práticas, por falta de recursos, por exemplo), como vemos em depoimentos de inúmeros colegas da área; tal experiência foi, e continua sendo, uma escola de vida pessoal e profissional, além de acentuar o meu interesse em pensar sobre os textos de Rousseau acerca da educação, de tentar refletir sobre caminhos que possam despertar reflexões sobre a possibilidade de a escola educar para formar o homem e o cidadão.

Ainda que o interesse em estudar temas ligados à questão da educação para cidadania já existisse desde o início da minha formação, com certeza foi acentuado a partir da experiência com as aulas de Filosofia, pois embora seja comum ouvirmos falar que a escola deve formar o cidadão - tanto em documentos como os Parâmetros Curriculares Nacionais (PCNs), como nos planejamentos, nas reuniões pedagógicas etc - é evidente que essa preocupação, pelo menos na grande maioria dos casos, é estritamente teórica e burocrática.

A partir dessa constatação, o meu interesse em pesquisar esse tema se acentuou, fazendo surgir também uma preocupação em trazê-lo à tona, numa tentativa de explicitar o que significa realmente a educação para cidadania, se é possível e de que maneira ela pode se concretizar.

Embora existam inúmeros autores que abordem o tema educação para cidadania, acredito que poucos tenham tanta propriedade quanto Rousseau, um filósofo que desde o século XVIII apontou princípios essenciais para educação formal e informal, demonstrando, além de grande interesse e envolvimento acerca do tema, uma perspicácia atemporal, cujas idéias ainda hoje iluminam estudos acerca da educação, como, por exemplo, sua preocupação com a formação do 
educando para que conquiste autonomia, liberdade e para que essa formação englobe o âmbito físico, moral, intelectual e social. Daí sua relevância para a pesquisa.

Esta pesquisa, além de ser uma oportunidade de crescimento intelectual acerca da teoria rousseauniana, é uma possibilidade de contribuição para minha vida profissional, já que Rousseau aborda conceitos e critérios que podem contribuir para uma reflexão pedagógica direcionada à formação global e profunda do aluno, levando tanto o educando quanto o educador a refletir sobre seu papel enquanto ser moral e social e dando-lhe uma nova perspectiva, um olhar mais profundo e reflexivo sobre o mundo. 


\section{INTRODUÇÃO}

O interesse pelo tema da educação de adolescentes para a cidadania surgiu devido a duas constatações realizadas durante as aulas, em escolas públicas e particulares, de Ensino Médio. A primeira diz respeito à demonstração de falta de envolvimento dos adolescentes em relação ao processo educativo, posto que muitos jovens não se comprometem com os estudos, não prestam atenção às aulas, não fazem as atividades solicitadas, preferem copiar coisas prontas ou, ainda, pedem para que o professor "não dê nada" e fique somente conversando, demonstrando excessiva alegria quando as aulas são canceladas.

Esse fator se deve, de certo modo, à ausência de um projeto de educação que conscientize os estudantes para a idéia de que há um investimento - como o pagamento de impostos - que eles mesmos fazem na educação e que mostre a utilidade de se construir o conhecimento, seja para crescimento pessoal ou tendo em vista as necessidades futuras, como aquelas referentes à profissionalização, o que já demonstra a necessidade de se pensar uma educação voltada para a conscientização política.

A segunda constatação sobre o cotidiano escolar refere-se à ausência de discussões acerca do referencial que se tem para falar e ensinar cidadania. Nas reuniões entre educadores professores, coordenadores, diretores etc - fica evidente que a formação dos mesmos poderia ser mais bem direcionada no que diz respeito a leituras e estudos minuciosos relacionados aos temas educativos. É muito comum discutir-se questões sobre a vida pessoal dos alunos no sentido pejorativo, sem demonstração de interesse em entender esse aluno como um ser humano que está em processo de construção da sua personalidade, que precisa de um referencial - como o professor - no que se refere à formação pessoal, profissional, ética e política.

Em outras palavras, muitos educadores não têm o compromisso de considerar o aluno como a parte indispensável do processo educativo e, menos ainda, em se preparar teoricamente para enfrentar problemas práticos, como o da formação para a cidadania. O que se percebe é um interesse burocrático em tratar o tema, mas praticamente nenhum compromisso em tentar relacioná-lo com a realidade ou aplicá-lo no cotidiano escolar.

Nesse período, ao mesmo tempo tive contato com crianças desde os seis anos até jovens de vinte anos ou mais, e então foi possível perceber diferenças no que diz respeito à postura que ambos têm em relação ao comprometimento com os estudos, com a formação escolar, 
especialmente em relação à convivência no ambiente escolar e receptividade aos professores e em relação às disciplinas.

As crianças se mostraram carinhosas, receptivas e respeitosas em relação ao professor e aos conteúdos, tendo uma postura afetiva e amigável com os colegas e estando sempre dispostas a discutir os temas propostos, bem como em realizar as pesquisas e as atividades solicitadas, enquanto muitos adolescentes adotaram uma postura de testar constantemente a postura do professor, apresentando um comportamento prejudicial ao andamento das aulas, como, por exemplo, gritando, xingando os colegas, ignorando o professor presente na sala, como se pedissem limites, mas de uma maneira descomprometida com seus deveres enquanto alunos e, ainda, testando a capacidade dos professores de mostrar-lhes a utilidade e os objetivos da disciplina, não de uma forma construtiva ou participativa, mas tentando "boicotar" a aula.

Desse modo, ficou evidente que a discussão acerca de assuntos relacionados ao tema cidadania é muito mais proveitosa com as crianças do que com os adolescentes, posto que as mesmas se mostram mais dispostas a questionar a postura de quem as cerca sem se preocupar, por exemplo, com o julgamento que farão dela ou com a possibilidade de quebrar o vínculo afetivo, isto é, as crianças demonstram estar mais distantes dos preconceitos e da idéia de que quando se gosta de alguém é preciso concordar com tudo que esse alguém pensa, como em situações que os adolescentes se deixam levar pelas opiniões do grupo para ser aceito. Enfim, as crianças, além dessa facilidade de se expor mesmo frente às diferenças no que diz respeito ao jeito de pensar, têm uma curiosidade típica, um desejo intenso de entender e participar das coisas que as cercam.

Essa constatação contribuiu para que o interesse em pensar a educação de adolescentes se acentuasse, pois nessa faixa etária, há mais necessidade de se estimular um pensamento crítico e participativo no que diz respeito às questões políticas, já que uma das funções da escola é direcionar a formação do adolescente para que o mesmo possa exercer o papel de cidadão.

Embora um caso isolado não seja o suficiente para constatar a necessidade de se pensar o tema, é interessante apontar um exemplo. A direção de uma escola propôs a organização de um Grêmio Estudantil: após inúmeras discussões com alunos representantes de todas as salas, e de conversas com todos os alunos da escola, ou seja, quando o tema havia sido tratado com todos, partiu-se para a propaganda eleitoral, quando um aluno do Ensino Médio tentou "comprar" os votos de algumas alunas do Ensino Fundamental I e tiveram a seguinte resposta: "Nós sabemos 
muito bem que o Grêmio é para ajudar os alunos a conseguirem coisas que precisamos na escola, e que temos que votar em quem achamos que vai fazer isso bem, alguém que vá fazer coisas do interesse dos alunos e não em quem quer "comprar" nosso voto. Você pensa que a gente é boba?" $\mathrm{O}$ adolescente ficou pasmo, demonstrando surpresa e, ao mesmo tempo, vergonha, e, a partir de então, mudou de postura, tratando-as com mais respeito.

Outra situação ocorrida ainda durante a propaganda eleitoral, que também causou espanto e alegria aos educadores envolvidos, foi quando alguns alunos analisaram o nome da chapa candidata à direção do Grêmio Estudantil. Os alunos candidatos eram da $8^{\mathrm{a}}$ série do Ensino Fundamental e, aproveitando a "febre" das crianças em relação ao grupo Rebeldes, que estava fazendo sucesso na época, colocaram o nome da chapa de RBD - sigla utilizada para identificar o grupo - com a intenção de coagir as crianças a votarem neles, quando alunos do Ensino Fundamental I comentaram que os alunos da chapa em questão estavam tentando enganá-los, mas eles sabiam que "uma coisa não tinha nada a ver com a outra" e que não votariam nos candidatos do "RBD".

E, ainda, houve uma outra situação com alunos do Ensino Fundamental I, quando justamente num bimestre em que estudávamos o tema animais, apareceu uma aranha na sala de aula, que foi presa num vidro. Perguntados sobre o que deveríamos fazer com o animalzinho, os alunos sugeriram que fizéssemos uma discussão, onde cada um daria sua opinião, justificando-a e, em seguida, votariam sobre o destino da aranha, que foi colocada de volta numa mata nas redondezas da escola. Houve uma discussão bastante organizada, assim como a votação - o que demonstrou uma maturidade em relação a participação democrática na "assembléia", bem como em relação a discussão em torno dos direitos e deveres em relação à vida e ao respeito por todas as espécies.

Em inúmeras outras situações como essa, foi possível perceber o envolvimento com discussões sobre política e cidadania na escola, momentos nos quais as crianças discutiram, levantaram hipóteses e pensaram na possibilidade de melhorar a situação política atual, enquanto os adolescentes parecem se negar a aprender, a pensar, limitando-se a informações baseadas no senso comum, como a idéia de que nada temos a ver com a política ou coisas do gênero.

É claro que esse fator não pode ser considerado de modo isolado em relação a todo o contexto escolar, que apresenta vários problemas, como a formação dos educadores, as condições de trabalho destes, a realidade do grupo de alunos atendidos pela escola, o envolvimento da 
comunidade escolar, enfim, não se trata de pensar a questão proposta como se não houvesse a intervenção nos problemas existentes na realidade atual, mas de tratar da perspectiva que nos desperta mais interesse e maior preocupação no momento.

Assim, o interesse em pensar a questão educação de adolescentes para a cidadania se acentuou, fazendo com que, ao ler Rousseau durante a Iniciação Científica, o olhar se direcionasse automaticamente para o tema, isto é, para os apontamentos que o autor faz em relação a esse assunto no decorrer do Emílio. E como o próprio autor valoriza a fase da juventude, tratando enfaticamente dela nos livros IV e $\mathrm{V}$ e fazendo várias referências a ela no decorrer da obra, a questão se tornou cada vez mais instigante.

Então, esta pesquisa acerca da educação de adolescentes para a cidadania se realizará da seguinte forma:

Num primeiro capítulo, será necessário explicitar conceitos desenvolvidos por Rousseau no Discurso sobre a Origem da Desigualdade, como o de estado de natureza, bondade natural, piedade natural, amor de si e estado civil, dentre outros, para constituir um panorama acerca do campo conceitual "natureza" e, a partir daí, definir como se dá a educação que segue a marcha da natureza, cuja função é impedir o desenvolvimento artificial do homem, ou seja, este deve ser educado de acordo com os princípios naturais, que pressupõe uma moralidade. De onde surge o conceito de educação negativa, idéia fundamental do pensamento rousseauniano no que diz respeito à educação, cujo papel é impedir que o educando seja corrompido pelos vícios próprios da vida em sociedade.

A partir da análise do conceito de educação negativa, vê-se que ele se direciona explicitamente para a educação doméstica e, implicitamente, para a educação pública, e que a presença desses preceitos em grande parte da obra, demonstra que, para Rousseau, para que a educação tenha chance de sucesso, é essencial que ambas ocorram desde o nascimento até a maturidade, ou seja, é importante que se realize bem a educação doméstica, no âmbito familiar e pessoal e, automaticamente, a educação pública, no âmbito social e político.

No segundo capítulo será realizada uma análise da formação do homem e do cidadão, demonstrando que Rousseau almeja a realização simultânea de ambas quando aponta princípios da educação doméstica. Isto é, mesmo frente a uma sociedade degenerada ou corrompida, o autor acredita na possibilidade de se educar desde a infância estabelecendo uma base para a formação do cidadão. Para que haja essa formação para a cidadania, Rousseau acredita que é necessário que 
o educando conheça a estrutura e o funcionamento da sociedade enquanto comunidade política, o que se dá através das viagens e, por sua vez, demonstra a necessidade de pensarmos alguns aspectos atuais acerca da cidadania, o que será feito tendo em mente a necessidade de, frente a ausência de uma cidadania no sentido grego, efetivarmos uma educação cidadã para, quem sabe, construirmos uma comunidade política que alcance um bom nível na escala de medidas.

No terceiro capítulo, depois de demonstrar que, no decorrer do Emílio, embora Rousseau trate diretamente da educação doméstica, isto é, da formação do homem, está tratando também da formação do cidadão, ou seja, que educar para a vida privada é educar para a vida pública, será preciso pensar, considerando que o eixo da pesquisa é a educação de adolescentes para a cidadania, algumas características tanto do adolescente apontado por ele quanto do atual, bem como alguns aspectos relevantes para que se oriente bem a educação desse jovem. E, ainda, serão mencionadas algumas idéias dos jovens acerca da política, numa tentativa de demonstrar a importância e a necessidade de formá-los para a vida pública, para a conscientização e participação política.

Tendo traçado o perfil do adolescente e constatado que a educação desenvolvida no Emílio é uma educação que se volta também para a cidadania, será preciso apontar quais princípios são considerados essenciais, no decorrer da obra, para que essa educação se efetive, a fim de tomá-los como um referencial na educação dos jovens.

A análise desses princípios será realizada no quarto capítulo, tendo em vista a preocupação de selecionar aqueles que se relacionam diretamente com a vida social ou ainda, aqueles que são tratados com ênfase pelo autor, como por exemplo, os princípios de utilidade, necessidade e liberdade. Ou seja, o estudo acerca desses preceitos tem o objetivo de oferecer aos educadores uma oportunidade de reflexão acerca de idéias que são essenciais na formação do homem e do cidadão, possibilitando a "utilização" desses princípios como referencial teórico para nortear a prática educativa voltada para a cidadania.

Por fim, no quinto capítulo, será realizado um apontamento em torno das perspectivas que podemos ter acerca da educação depois de ter estabelecido que é possível direcionar a formação do adolescente para a cidadania, mas que, para tanto, é preciso haver mudanças no contexto escolar e, essencialmente, em algumas atitudes que norteiam a educação, como aquelas que menosprezam a participação democrática dos alunos, ou ainda, em relação às atitudes preconceituosas existentes no contexto escolar. 
Desse modo, embora este não seja o foco da pesquisa, é essencial apontar para a idéia de que é necessário que hajam políticas públicas comprometidas com a boa formação dos educadores, para que os mesmos possam se preparar teoricamente e, assim, possam desenvolver uma prática voltada para a participação ativa e consciente em relação à formação dos educandos para a cidadania, o que é indispensável. E, ainda, é através da valorização da profissão docente que pode haver a garantia de uma postura comprometida com a necessidade de se demonstrar aos jovens a importância da escola em suas vidas, propiciando a busca por uma educação de qualidade, num contexto dinâmico e democrático. 


\section{EDUCAÇÃO DOMÉSTICA E EDUCAÇÃO PÚBLICA}

O capítulo presente pretende apontar conceitos desenvolvidos no Discurso sobre a Origem da Desigualdade entre os Homens, tais como o de estado de natureza, bondade natural, piedade natural, estado civil, entre outros. Essas breves considerações se devem a necessidade de apreender esse campo conceitual para tratar dos temas relacionados à educação, que deve seguir a marcha da natureza. Em outras palavras, é necessário entender o que é a natureza em Rousseau, bem como o homem natural, para tratar da educação baseada nos princípios inerentes ao desenvolvimento natural do homem.

Essa educação voltada para a natureza se relaciona diretamente com a idéia de impedir vícios morais no educando, que são próprios da vida em sociedade, daí a necessidade de explorar o conceito de educação negativa, bem como de como se dá a educação doméstica que, por sua vez, forma para a moralidade, educa o indivíduo.

Por fim, será apontada a idéia de que a educação voltada para a formação do homem está implicitamente ligada a formação do cidadão, vínculo que será mais bem explorado no capítulo seguinte.

Rousseau inicia seu tratado de educação enfatizando a importância do estado de natureza em relação ao estado civil, descritos no Discurso, obra na qual o autor aponta as características hipotéticas humanas primárias, quando o homem ainda não tinha se socializado e vivia como qualquer outro animal, nas florestas.

Essa importância se deve aos aspectos da vida que se vivia no contato direto com a natureza, o que demonstra uma espécie de respeito e valorização em relação à constituição original do homem, segundo a hipótese de evolução descrita pelo próprio autor. Para ele as coisas - assim como o homem - estão bem se conservadas como no estado de natureza ou o mais próximo possível dele, ao passo que, no estado civil, elas se degeneram, se corrompem: "Tudo está bem quando sai das mãos do autor das coisas, tudo degenera entre as mãos do homem". ${ }^{1}$

Embora esta pesquisa não tenha como foco as idéias desenvolvidas pelo autor no Discurso sobre a Origem da Desigualdade entre os Homens, é importante ressaltarmos o valor

\footnotetext{
${ }^{1}$ ROUSSEAU, Emílio, p. 07.
} 
dessas idéias em relação às outras obras rousseaunianas, posto que há conceitos desenvolvidos, como o estado de natureza, o estado civil, o homem natural etc, que são fundamentais para entendermos sua concepção de educação. E como o eixo da pesquisa é a educação, é essencial apontarmos esses conceitos, que são indispensáveis para pensarmos a formação dos adolescentes voltada para a cidadania.

No Discurso, Rousseau descreve uma hipótese acerca de como se deu o desenvolvimento humano, especialmente em relação à origem da desigualdade social. Para pensar como os homens viviam originalmente, criou a imagem de um ser bastante primitivo, que vivia exclusivamente a vagar pelas florestas, em busca de suprir seus instintos mais elementares, como a fome, a sede e o instinto sexual. Nessa época não havia quaisquer espécies de convivência social, o homem vivia solitariamente, relacionando-se com a espécie somente para garantir a procriação, isto é, a preservação da espécie.

Rousseau supõe um ser contemplativo, sempre envolvido com seu ambiente, a floresta. Na hipótese desenvolvida pelo autor, o homem natural é um ser exclusivamente instintivo, que procura saciar suas necessidades de forma simples e natural, ou seja, quando sente fome procura o alimento ao seu redor, se tem sede busca um riacho para encontrar água, dorme ao relento quando tem sono e cede ao instinto sexual, sem estabelecer qualquer vínculo com a espécie.

Em relação a sua constituição física, o autor nos apresenta a idéia de um homem que anda sobre os dois pés, utilizando as mãos como o fazemos atualmente e, sobretudo, como uma robustez marcante, é forte, ágil e cheio de vigor físico, o que é próprio das atividades que realiza em busca de satisfazer suas necessidades, como quando luta com outros animais pelo alimento, quando foge deles, ou ainda, fugindo das catástrofes naturais.

Enfim, no que diz respeito às características físicas do homem natural, Rousseau prioriza o desenvolvimento natural das coisas:

(...) para bem julgar o estado natural do homem (...) não me deterei procurando no sistema animal o que poderia ter sido inicialmente para ter-se tornado o que é. (...) eu o suporei conformado em todos os tempos como o vejo hoje: andando sobre dois pés, utilizando suas mãos como o fazemos com as nossas, levando seu olhar a toda a natureza e medindo com os olhos a vasta extensão do céu. (...) Vejo-o fartando-se sob um carvalho, refrigerando-se no primeiro riacho, encontrando seu leito ao pé da mesma árvore que lhe forneceu o repasto e, assim, satisfazendo a todas as suas necessidades. (...) Habituados, desde a infância, às intempéries da atmosfera e ao rigor das estações, experimentados na fadiga e forçados a defender, nus e sem armas, a vida e a prole contra 
as outras bestas ferozes ou a elas escapar correndo, os homens adquirem um temperamento robusto e quase inalterável; os filhos, trazendo para o mundo a excelente constituição de seus pais e fortificando-a pelas mesmas atividades que a produziram, adquirem, desse modo, todo o vigor de que a espécie humana é capaz. ${ }^{2}$

Quanto ao aspecto metafísico, Rousseau, comparando o homem aos outros animais, aponta três características que os distingue entre si e que são essenciais na constituição do homem natural: a primeira delas é a liberdade, capacidade que faz com que o homem possa escolher entre coisas que possam lhe causar prejuízos ou benefícios, como por exemplo, no caso de precisar lutar com outro animal por alimento, ele pode optar pela luta ou pela fuga, dependendo das características, ou seja, da força física, de seu adversário:

\footnotetext{
Em cada animal vejo somente uma máquina engenhosa a que a natureza conferiu sentidos para recompor-se por si mesma e para defender-se, até certo ponto, de tudo quanto tende a destruí-la ou estragá-la. Percebo as mesmas coisas na máquina humana, com a diferença de tudo fazer sozinha a natureza nas operações do animal, enquanto o homem executa as suas como agente livre. Um escolhe ou rejeita por instinto, e o outro, por um ato de liberdade, razão por que o animal não pode desviar-se da regra que lhe é prescrita, mesmo quando lhe fora vantajoso fazê-lo, o homem, em seu prejuízo, freqüentemente se afasta dela. (...) Assim os homens dissolutos se entregam a excessos que lhes causam febre e morte, porque o espírito deprava os sentidos e a vontade ainda fala quando a natureza se cala. ${ }^{3}$
}

A segunda característica é a razão, aspecto que o permite utilizar suas idéias com intensidade, relacionando-as entre si, observando e analisando as coisas ao seu redor para escolhê-las ou rejeitá-las: "Todo animal tem idéias, posto que tem sentidos; chega mesmo a combinar suas idéias até certo ponto e o homem, a esse respeito, só se diferencia da besta pela intensidade". 4

E, por último, a perfectibilidade, habilidade que torna o homem capaz de desenvolver coisas em seus benefícios e, ao mesmo tempo, que o afastam do estado de natureza, como armas para caçar, por exemplo:

\footnotetext{
${ }^{2}$ ROUSSEAU, Discurso sobre a desigualdade, p. 243-4.

${ }^{3}$ Idem, p. 248-9.

${ }^{4}$ Ibidem, p. 248.
} 


\begin{abstract}
Mas, ainda quando as dificuldades que cercam todas essas questões deixassem por um instante de causar discussão sobre a diferença entre o homem e o animal, haveria uma outra qualidade muito específica que os distinguiria e a respeito da qual não pode haver contestação - é a faculdade de aperfeiçoar-se, faculdade que, com o auxílio das circunstâncias, desenvolve sucessivamente todas as outras e se encontra, entre nós, tanto na espécie quanto no indivíduo. ${ }^{5}$
\end{abstract}

Enfim, para Rousseau a constituição física e metafísica do homem natural, seu estilo de vida, sua liberdade e sua auto-suficiência, garantem uma vida privilegiada, pois viver no estado de natureza é, de certa forma, garantir a preservação das coisas como "saiu das mãos do autor das coisas", ou seja, garantir a vida humana em seu estado original, o que, por sua vez, seria um empecilho a degeneração própria do estado civil, onde a desigualdade e o desejo por privilégios fazem dos homens seres egocêntricos e descomprometidos com o coletivo.

Além disso, é importante ressaltar a ênfase dada pelo autor ao amor de si e à piedade natural, características que garantem, simultaneamente, o cuidado em relação a si mesmo e a capacidade de se colocar no lugar dos outros - a comiseração -, garantindo a preservação da espécie: "O amor de si mesmo é um sentimento natural que leva todo animal a velar pela própria conservação e que, no homem dirigido pela razão e modificado pela piedade, produz a humanidade e a virtude". 6

Afirma ainda que a piedade natural, no estado de natureza, é uma espécie de regulamentação das atitudes dos homens entre si fazendo com que se coloquem um no lugar do outro, que sintam o pesar e as dores dos outros, medindo suas atitudes em relação a estes. Dessa forma, há a garantia da preservação da espécie, já que um não vai aniquilar o outro, mas preservá-lo como o faria em relação a si mesmo. A piedade natural retrata a máxima da bondade natural, cujo princípio é causar o mínimo possível de prejuízos aos outros:

Certo, pois a piedade representa um sentimento natural que, moderando em cada indivíduo a ação do amor de si mesmo, concorre para a conservação mútua de toda a espécie. Ela nos faz, sem reflexão, socorrer aqueles que vemos sofrer; ela, no estado de natureza, ocupa o lugar das leis, dos costumes e da virtude, com a vantagem de ninguém sentir-se tentado a desobedecer à sua doce voz; ela impedirá qualquer selvagem robusto de tirar a uma criança fraca ou a um velho enfermo a subsistência adquirida com dificuldade, desde que ele mesmo possa encontrar a sua em outra parte; ela, em lugar dessa máxima sublime da justiça raciocinada - Faze a outrem o que desejas que

\footnotetext{
${ }^{5}$ Ibidem, p. 249.

${ }^{6}$ Ibidem, p. 312.
} 
façam a $t i$-, inspira a todos os homens esta outra máxima de bondade natural, bem menos perfeita, mas talvez mais útil do que a precedente - Alcança teu bem com o menor mal possível para outrem. $^{7}$

Assim, vemos que Rousseau aponta o estado de natureza, a vida simples, satisfazendo somente as necessidades básicas, como uma forma bastante privilegiada de se viver, apontando características próprias de um período em que o homem viveu harmoniosamente com ele mesmo, com a natureza e com a espécie.

No entanto, principalmente com as transformações da natureza, o homem precisou inventar uma nova maneira de viver e, por meio da perfectibilidade, desenvolveu novas habilidades, construindo instrumentos que o proporcionaram mais conforto, de onde surgiram novas necessidades e, assim, novas formas de vida, como a construção de instrumentos de caça, entre outras coisas. Assim surgiu também a construção das primeiras habitações, bem como a constituição das famílias e o início da convivência social.

Com a convivência social, os homens começam a se aproximar mais e, automaticamente, a se comparar entre si, despertando seu orgulho e, assim, seu desejo de ser melhor que os outros homens:

Tudo começa a mudar de aspecto. Até então errando nos bosques, os homens, ao adquirirem situação mais fixa, aproximam-se lentamente e por fim formam, em cada região, uma nação particular, uma de costumes e caracteres, não por regulamentos e leis, mas, sim, pelo mesmo gênero de vida e de alimentos e pela influência comum do clima. Uma vizinhança permanente não pode deixar de, afinal, engendrar algumas ligações entre as famílias. Jovens de sexo diferente habitam cabanas vizinhas, o comércio passageiro, exigido pela natureza, logo induz a outro, não menos agradável e mais permanente, pela freqüentação mútua. Acostumam-se a considerar os vários objetos e a fazer comparações, insensivelmente, adquirem-se idéias de mérito e de beleza, que produzem sentimentos de preferência. À força de se verem, não podem mais deixar de novamente se verem. Insinua-se na alma um sentimento terno e doce, e, à menos oposição, nasce um furor impetuoso; como o amor surge o ciúme, a discórdia triunfa e a mais doce das paixões recebe sacrifícios de sangue humano". 8

\footnotetext{
${ }^{7}$ Ibidem, p. 260.

${ }^{8}$ Ibidem, p. 269.
} 
E, ainda, nesse segundo estado, com a convivência social iniciada, os homens comparavam-se e, automaticamente, competiam entre si, com o objetivo de demonstrarem ser melhores uns que os outros e de conquistar a estima pública. Dessa competição surge o amor próprio em detrimento ao amor de si e, conseqüentemente, a piedade natural vê-se abafada pelo orgulho e pelo egocentrismo:

Cada um começou a olhar os outros e a desejar ser ele próprio olhado, passando assim a estima pública a ter um preço. Aquele que cantava ou dançava melhor, o mais belo, o mais forte, o mais astuto ou o mais eloquiente, passou a ser o mais considerado, e foi esse o primeiro passo para a desigualdade quanto para o vício; dessas primeiras preferências nasceram, de um lado, a vaidade e o desprezo, e, de outro, a vergonha e a inveja. A fermentação determinada por esses germes produziu, por fim, compostos funestos à felicidade e à inocência. ${ }^{9}$

A partir do momento em que os homens convivem socialmente, surge a necessidade de se fixar em determinado lugar, de onde surgiu a criação da propriedade privada, marco do desenvolvimento da desigualdade social. Na descrição hipotética realizada por Rousseau, é no decorrer da passagem do estado de natureza para o estado civil que se concretiza o processo de desigualdade:

O verdadeiro fundador da sociedade civil foi o primeiro que, tendo cercado um terreno, lembrou-se de dizer isto é meu e encontrou pessoas suficientemente simples para acreditá-lo. Quantos crimes, guerras, assassínios, misérias e horrores não pouparia ao gênero humano aquele que, arrancando as estacas ou enchendo o fosso, tivesse gritado a seus semelhantes: "Defendei-vos de ouvir esse impostor; estareis perdidos se esquecerdes que os frutos são de todos e que a terra não pertence a ninguém!",10

Assim, com o surgimento dos privilégios dos mais ricos (bens materiais), dos mais poderosos (poder, dominação) e dos homenageados (honra) em relação aos outros homens, há a acentuação da desigualdade social, fazendo com que a necessidade de poder corrompesse a humanidade, num estado de "guerra de todos contra todos":

\footnotetext{
${ }^{9}$ Ibidem, p.269.

${ }^{10}$ Ibidem, p. 265.
} 
Assim, os mais poderosos ou os mais miseráveis, fazendo de suas forças ou de suas necessidades uma espécie de direito ao bem alheio, equivalente, segundo eles, ao de propriedade, seguiu-se à rompida igualdade a pior desordem; assim as usurpações dos ricos, as extorções dos pobres, as paixões desenfreadas de todos, abafando a piedade natural e a voz ainda fraca da justiça, tornaram os homens avaros, ambiciosos e maus. (...) Assim, o estado de rico e de pobre foi autorizado pela primeira época; o de poderoso e de fraco pela segunda; e, pela terceira, o de senhor e escravo, que é o último grau da desigualdade... ${ }^{11}$

Rousseau descreve no Discurso duas formas de desigualdade: a desigualdade "natural", referente às características físicas (gênero, idade etc), espirituais (inteligência, por exemplo) e as relacionadas à alma (talentos), que é dada com o nascimento ou adquirida com as capacidades naturais da criança; e outra "moral ou política", referente aos privilégios adquiridos no decorrer da vida, por exemplo, dos mais ricos (bens materiais), dos mais poderosos (poder, dominação) e dos homenageados (honra).

A desigualdade natural independe da vontade dos homens, posto que lhe é dada pela própria natureza e de acordo com o desenvolvimento físico e intelectual de cada um. A desigualdade moral ou política, por sua vez, é algo ilegítimo, posto que não é naturalmente dada, mas estabelecida com o processo de desigualdade e consentida pelos próprios homens.

Daí pensarmos que o que "atesta" a ilegitimidade da desigualdade moral, política ou social é, por exemplo, em relação aos privilégios dos ricos, o fato de que "é manifestamente contra a lei da natureza, seja qual for a maneira por que a definamos (...) um punhado de pessoas regurgitar superfluidades enquanto à multidão faminta falta o necessário". ${ }^{2}$

Embora, no decorrer do Discurso, Rousseau tenha demonstrado sua admiração pelo estado de natureza, bem como pelo homem natural, isso não significa dizer que ele esteja apontando para idéia de que devêssemos retornar a vida entre as florestas, como na hipótese descrita acerca da natureza. $\mathrm{O}$ autor faz tal descrição para demonstrar o desenvolvimento humano até a modernidade, incluindo a situação da sociedade civil, com o objetivo de nos ajudar a compreender, especialmente, o processo de instituição da desigualdade social, isto é, Rousseau não pressupõe a possibilidade de inexistência do estado de sociedade ou a volta ao estado de

\footnotetext{
${ }^{11}$ Ibidem, p. 274 e 283.

${ }^{12}$ Ibidem, p. 288.
} 
natureza, pelo contrário, ele admite que: "no estado em que agora as coisas estão, um homem abandonado a si mesmo desde o nascimento entre os outros seria o mais desfigurado de todos". ${ }^{13}$

Como Rousseau considera a idéia de que é inevitável vivermos na sociedade como está atualmente e que não é possível abandonar o homem a própria sorte, fica evidente que é preciso encontrar um instrumento que auxilie na formação do homem e no estabelecimento de princípios que norteiem suas atitudes para uma convivência harmoniosa e respeitosa entre os homens, afinal, o amor de si e a piedade natural estão abafados nesse estado.

Considerando a necessidade de uma formação adequada ao homem que vive na sociedade do estado civil, isto é, numa sociedade degenerada, desprovida do amor de si e da piedade natural - paixões essenciais para a conservação da espécie no estado de natureza -, Rousseau retrata, no Emílio, os princípios dessa educação para o homem civilizado, que não tem o respaldo da natureza para que o seu desenvolvimento seja adequado: "Tudo que não temos ao nascer e de que precisamos quando grandes nos é dado pela educação". ${ }^{4}$

Essa educação, que nos garante tudo que precisamos no decorrer da vida, embora não seja a questão central do Discurso - que é a origem da desigualdade entre os homens -, aponta para princípios baseados na educação voltada para a natureza, ou seja, é preciso entender o que o autor entende por natureza para entendermos o que seria a "educação que segue a marcha da natureza", como almeja no Emílio. E, por sua vez, é essencial ponderar sobre a descrição do estado civil, para que seja possível entender a necessidade de uma educação especialmente voltada para esse estado, que está degenerado.

Daí ser indispensável relacionar alguns aspectos do estado de natureza e do estado civil, para entendermos porque Rousseau, inicialmente, aponta para a idéia de que é preciso educar para a vida particular, através da educação doméstica, para só mais tarde vinculá-la à formação para a vida social, através da educação pública.

Em outras palavras, o autor defende a idéia de uma educação inicialmente voltada para o âmbito familiar, onde há mais possibilidade de garantir uma formação baseada nos mesmos princípios educativos, para só mais tarde, quando já houve a formação do indivíduo, ou a consolidação de uma espécie de alicerce da educação, inserí-lo na vida em sociedade, quando

\footnotetext{
${ }^{13}$ Idem.

${ }^{14}$ Ibidem, p. 08.
} 
supostamente estará pronto para conviver com a degeneração e a corrupção próprios do estado civil, sem se deixar contaminar.

Ao mesmo tempo em que Rousseau apresenta a preocupação em descrever um processo educativo ideal em relação à realidade da sociedade atual quanto à educação vigente, tem também uma apreensão quanto à organização política dessa sociedade, o que corresponderia a dizer que, ao escrever, simultaneamente, o Emílio e o Contrato Social, apresentando, de um lado, suas hipóteses acerca de um processo educativo desde antes do nascimento até a maturidade e, de outro, suas considerações acerca do que vem a ser a melhor sociedade política, pensa na possibilidade de um homem ideal para uma sociedade política ideal.

Nesses projetos pressupõe uma formação integral, na qual o educando tenha possibilidades de se formar enquanto homem e cidadão, isto é, seu projeto pressupõe a formação moral e política do homem, para que este possa fazer parte de uma sociedade que também se organize moral e politicamente.

No que diz respeito a esse processo de formação moral, Rousseau inicia sua defesa da necessidade de reforma da educação vigente com a idéia de que existem três tipos de educação:

Essa educação vem-nos da natureza, ou dos homens ou das coisas. O desenvolvimento interno de nossas faculdades e de nossos órgãos é a educação da natureza; o uso que nos ensinam a fazer desse desenvolvimento é a educação dos homens; e a aquisição de nossa própria experiência sobre os objetos que nos afetam é a educação das coisas. ${ }^{15}$

Além de apontar a idéia de que o homem é educado por três tipos de educação, Rousseau enfatiza ainda, a necessidade de que durante o processo educativo, essas três educações sejam norteadas pelos mesmos princípios - que serão comentados ao longo da pesquisa - para que obtenham sucesso:

Assim, cada um de nós é formado por três tipos de mestres. O discípulo em quem suas diversas lições se opõem é mal educado e jamais estará de acordo consigo mesmo; aquele em quem todas elas recaem sobre os mesmos pontos e tendem aos mesmos fins vai sozinho para seus objetivos e vive conseqüentemente. Só esse é bem educado. ${ }^{16}$

\footnotetext{
${ }^{15}$ Ibidem, p. 08-9.

${ }^{16}$ Ibidem, p.09.
} 
Devido à necessidade de que a criança tenha educações que sigam os mesmos parâmetros de formação do educando, trata-se, hipoteticamente, de uma criança órfã e solitária, sem família, para que no processo educativo se observe esse princípio, sem que a influência de "educações controversas" possam romper com a idéia de um único projeto norteador.

Rousseau desenvolve esse processo educativo seguindo a faixa etária do educando, daí começar pela educação doméstica, ou seja, pela educação voltada para o âmbito familiar, já que “a instituição pública não existe mais, e não pode mais existir, já que onde não há mais pátria não pode mais haver cidadãos". ${ }^{17}$ Isto é, considerando que o estado civil, que representa a idéia que Rousseau tinha de sua atualidade, é um estado de extrema desigualdade, onde o homem não tem garantido seus direitos de cidadão, nem conhece o funcionamento político da sociedade em que vive, é impossível que interaja nessa sociedade politicamente, de onde se segue que não há possibilidade de haver cidadão, no sentido daquele que participa democraticamente das decisões políticas.

Então, considerando o estado em que as coisas se encontram na sociedade civil descrita por Rousseau no Discurso, o autor afirma que será necessário "impedir que algo seja feito", de onde vem o conceito de educação negativa, ou seja, de um processo educacional que tenha como critério evitar tudo aquilo que previna os vícios próprios do estado civil, como a inveja, a vaidade e o desprezo, características próprias da degeneração moral que ocorre comumente neste estado.

Em outras palavras, se não é possível educar o cidadão, é preciso educar o homem, formálo moralmente, impedindo a degeneração de seu caráter, mantendo algumas de suas características naturais, como o amor de si e a piedade natural.

A educação negativa deve ser uma espécie de princípio orientador para a educação doméstica, no qual o autor demonstra que é necessário salvar o indivíduo, afastando-o dos vícios da sociedade corrompida, como vemos na interpretação do Emílio, de Salinas Fortes:

O que é salvável nas grandes sociedades corrompidas é o indivíduo ou alguns indivíduos que tenham a sorte de permanecer um pouco à sua margem. Emílio, esse personagem de ficção, simboliza esse indivíduo. Posto desde o nascimento em contato íntimo com a natureza, tomando-a sempre como guia, ele é educado para conviver e suportar a vida em uma grande sociedade corrompida, onde já não há perspectivas de salvação global porque já não tem leis, nem pátria, nem

\footnotetext{
${ }^{17}$ Ibidem, p. 12.

${ }^{18}$ Ibidem, p. 13.
} 
corpo político. Toda sua educação, caracterizada como "educação negativa”, visa a mantê-lo imune aos vícios circundantes. É bem-sucedida a educação que conseguir fazer o indivíduo em formação acompanhar a "marcha da natureza", reprimida pela marcha enlouquecida das educações vigentes. Além de ser um tratado pedagógico crítico, o Emílio é também um tratado sobre a bondade natural do homem, ao reconstituir as etapas naturais de formação do indivíduo humano, assim como o Discurso fez em relação à espécie. ${ }^{19}$

Como afirma Salinas Fortes, Rousseau acredita que a educação deve, acima de tudo, seguir a marcha da natureza, fazendo com que se mantenha no coração do educando características que lhes são próprias, como por exemplo, a bondade e a piedade naturais. Isto é, para o autor, podemos nos orientar pela natureza se impedirmos os vícios (educação negativa) da vida em sociedade e cuidarmos para que o educando se desenvolva naturalmente, seguindo as inclinações inerentes ao desenvolvimento humano.

E, ainda, quando se trata da educação voltada para as regras da natureza, Pissarra afirma que é preciso educar Emílio para que possa viver da melhor maneira possível em sociedade, isto é, preservando suas qualidades naturais e impedindo-o da degeneração pelos vícios, como os preconceitos. Para tanto, o educando deveria fazer uso da razão que, por sinal, é uma das características metafísicas do homem natural, cuja função é uma reflexão em torno das decisões que precisa tomar, das escolhas que precisa fazer como, por exemplo, optar pelas qualidades naturais, preservando-se dos vícios:

Em vez de educar Emílio para um determinado papel social, como é o procedimento comum em sociedade, propõe educá-lo para ser homem, isto é, segundo a natureza, para melhor viver em sociedade, guardando as qualidades naturais. Mas o que é ser educado segundo a natureza? Significa deixar de lado todos os preconceitos e deixar-se guiar apenas pela razão - esta será seu único guia. E esse também será o caráter revolucionário desse novo homem: não aceitar nada, nenhum dos valores estabelecidos na sociedade, sem fazê-los antes ser aceitos pela razão. ${ }^{20}$

Embora o foco da pesquisa seja a educação de adolescentes para a cidadania, é importante definir as características defendidas por Rousseau no que diz respeito à constituição do homem natural, como por exemplo, a bondade e a piedade natural, que são características típicas desse homem hipotético, assim como é necessário apontar como se dá a vida em natureza

\footnotetext{
${ }^{19}$ FORTES, O bom selvagem, p. 94-5.

${ }^{20}$ PISSARRA, p. 58.
} 
e quais aspectos são relevantes para o autor, posto que para entender o que ele quer dizer com "a educação deve seguir a marcha da natureza", é preciso entender o que prescreve a vida natural, estabelecendo princípios que direcionem para essa formação que funciona como um parâmetro para se pensar o processo educativo.

No transcorrer de todo o Emílio vemos Rousseau descrever um processo de educação doméstica - baseado no princípio de seguir a marcha da natureza - com cada detalhe e preocupado com a formação de um homem virtuoso, que possa preservar o máximo possível suas qualidades naturais, e que jamais possa transgredir seus princípios em nome de vícios e da imoralidade da sociedade corrompida.

Ou seja, a educação da natureza pode ser preservada através da educação negativa, que, impedindo o educando de adquirir inclinações negativas (vícios, como o egoísmo, por exemplo), o mantém semelhante ao estabelecido na hipótese do homem natural.

Para Rousseau, a educação doméstica deve ocorrer no âmbito familiar, onde a criança deve ser educada, preferencialmente, pelos pais, pois o autor acredita que eles são os melhores instrutores do educando, posto que além da proximidade natural, há o laço afetivo, que é fundamental para o sucesso da formação do homem. Mas como no Emílio considera-se a idéia de que os educadores devem seguir os mesmos princípios, faz-se necessário introduzir um preceptor, que representa a concepção de um educador ideal.

Então, Emílio terá sua educação direcionada por esse educador ideal, o preceptor, que incontestavelmente, deve seguir a marcha da natureza, isto é, a educação negativa, e que, acima de tudo, não pode ser um homem passível de suborno ou corrupção e deve ser um exemplo de homem em relação à formação moral e política, "lembrai-vos de que, antes de ousar empreender a formação de um homem, é preciso ter-se feito homem; é preciso ter em si o exemplo que se deve propor". ${ }^{21}$

O preceptor deve ser o mais jovem possível para um homem sábio e terá um único aluno, que o será desde o nascimento até os 25 anos, quando os deveres de homem já estiverem absorvidos por Emílio. Este acompanhamento deve ser por toda vida, já que Rousseau acredita que a criança começa a se instruir a partir do momento em que nasce, mesmo antes de falar e ouvir. Por Emílio ser órfão, o preceptor tomará totalmente o lugar de seu pai, tomando para si os seus deveres e, conseqüentemente, seus direitos.

\footnotetext{
${ }^{21}$ ROUSSEAU, Emílio, p. 93.
} 
É essencial que Emílio não tenha outros educadores além da ama-de-leite (já que se trata de uma criança que é órfã) e especialmente, do preceptor. Como vimos, para Rousseau, quanto menos pessoas participarem da educação da criança, maior será o sucesso da formação do homem: "a escolha da ama-de-leite é tanto mais importante quanto sua criança não deve ter outra ama além dela, assim como não deve ter outro preceptor. Esse era o costume dos antigos, menos raciocinadores e mais sábios do que nós". ${ }^{22} \mathrm{E}$, se possível, "para ser bem dirigida, a criança deve seguir um só guia"23, o que possibilita que sua educação não seja desenvolvida com incoerências ou contradições, tendo como base uma formação com princípios morais únicos, o que fortalece a idéia de educação negativa, isto é, tendo os mesmos princípios, impede-se os mesmos vícios.

Embora desde o livro I do Emílio, Rousseau demonstre priorizar a educação doméstica, isto é, a formação do homem, logo no início de sua obra é possível perceber sua preocupação implícita com a formação do cidadão: "Resta enfim a educação doméstica ou da natureza, mas o que se tornará para os outros [formação do cidadão] um homem que tenha sido educado unicamente para si mesmo [formação do homem]?"24

Evidenciando essa preocupação, descreve algumas idéias que estão relacionados à questão da formação cidadã, ainda que não esteja educando diretamente para cidadania e para a vida social. Uma dessas idéias diz respeito à liberdade, conceito que será explorado pelo autor a partir da noção de que é preciso, desde a infância, conscientizar a criança da importância de usar o bom senso para fazer escolhas ou tomar atitudes, embora, ao mesmo tempo em que é um ser livre, depende dos homens e das coisas. Rousseau afirma que a dependência das coisas é mais saudável no início da formação do educando, pois por não pressupor vínculo social, preserva o homem dos vícios:

Existem dois tipos de dependência: a das coisas, que é da natureza, e a dos homens, que é da sociedade. Não tendo nenhuma moralidade, a dependência das coisas não prejudica a liberdade e não gera vícios; a dependência dos homens, sendo desordenada, gera todos os vícios, e é por ela que o senhor e o escravo depravam-se mutuamente. ${ }^{25}$

\footnotetext{
${ }^{22}$ Idem, p. 38.

${ }^{23}$ Ibidem, p. 15.

${ }^{24}$ Ibidem, p. 13.

${ }^{25}$ Ibidem, p. 77-8.
} 
Embora as idéias de dependência e liberdade pareçam paradoxais, Rousseau as utiliza para mostrar seu conceito de liberdade:

(...) o primeiro de todos os bens não é a autoridade, mas a liberdade. O homem verdadeiramente livre só quer o que pode e faz o que lhe agrada. Eis a minha máxima fundamental. Trata-se apenas de aplicá-la à infância, e todas as regras da educação decorrerão dela. ${ }^{26}$

Rousseau deixa claro que ser livre é estar consciente de suas necessidades e de como realizá-las, isto é, ser livre não pressupõe fazer o que bem entender, mas compreender o que se pode ou não fazer dentro das suas limitações e de seus valores morais. Daí a idéia de que a dependência das coisas não prejudica a liberdade e não gera vícios, pois depender das coisas não significa estar preso à vontade de outrem, mas à necessidade e utilidade, que são princípios educativos de base na educação.

Em outras palavras, o princípio de liberdade deve estar eternamente ligado ao bom senso, pois nem tudo deve ser permitido à criança, e sim apenas o que lhe é realmente necessário e útil, não se pode deixar que ela ordene que se cumpra os seus desejos, mas que sejam concedidos quando forem convenientes, ou seja, também devem existir regras para a liberdade. ${ }^{27}$

Rousseau afirma que durante a infância, a educação doméstica deve se preocupar diretamente - de uma única lição moral, a de que não se pode fazer o mal: "A única lição de moral que convém à infância, e a mais importante em todas as idades, é a de nunca fazer mal a alguém. O próprio preceito de fazer o bem, se não estiver subordinado a este, é perigoso, falso e contraditório". 28

Rousseau reconhece que, a princípio, a lição de solidariedade não será compreendida, mas afirma que será útil, mesmo que seja realizada por imitação:

Sei que todas estas virtudes por imitação são virtudes de macaco, e nenhuma boa ação é moralmente boa a não ser quando a fazemos como tal, e não porque outros a fazem. Numa idade, porém, em que o coração ainda nada sente, devemos fazer com que as crianças imitem os atos cujo

\footnotetext{
${ }^{26}$ Ibidem, p. 76.

${ }^{27}$ Os princípios, como liberdade, utilidade e necessidade, serão aprofundados no quarto capítulo, sobre princípios educativos apresentados por Rousseau no Emílio.

${ }^{28}$ ROUSSEAU, Emílio, p. 109.
} 
hábito lhes queremos dar, enquanto elas não os possam fazer por discernimento e por amor ao bem. $^{29}$

Para Rousseau é extremamente importante que só se ensinem para criança coisas das quais realmente precisa, por meio do princípio fundamentado na necessidade, ou seja, é preciso que desde cedo o educando saiba conciliar os desejos e as necessidades, que devem ser norteadas pelas leis da natureza que, por sua vez, previnem prejuízos futuros, como a própria perda da liberdade:

$\mathrm{O}$ autor das coisas não provê apenas as necessidades que nos dá, mas também àquelas que nós próprios nos damos, e é para que nosso desejo esteja sempre ao lado de nossa necessidade que ela faz com que nossos gostos mudem e se alterem com as maneiras de viver. (...) Viu-se alguma vez alguém que tivesse aversão pelo pão ou pela água? Eis o rastro da natureza, eis portanto também a nossa regra. Conservemos na criança o seu gosto primitivo o mais possível (...) não estou examinando aqui se essa maneira de viver é mais sadia ou não, não é assim que o encaro. Basta-me saber, para preferi-la, que é a mais conforme à natureza, e a que pode com maior facilidade dobrarse a qualquer outra. (...) Sempre renascente, a lei da necessidade cedo ensina o homem a fazer o que não gosta para prevenir um mal que lhe desagradaria ainda mais. Este é o uso da previdência, e da previdência bem ou mal ordenada nasce toda a sabedoria ou toda a miséria humana. ${ }^{30}$

Considerando essa previdência, que podemos chamar de bom senso, o que leva o homem a agir com sabedoria, a agir bem, Rousseau acredita que Emílio, na infância, deve, sempre que possível, através de exemplos e de experiências concretas, ter noções gerais de caridade, propriedade e verdade, mas estes conceitos não devem ser enfatizados constantemente e até a maturidade, afinal, não podemos esquecer que um dos princípios da educação rousseauísta é o de utilidade e não parece útil que uma criança tenha absoluta compreensão em torno desses conceitos, que são subjetivos.

Para Rousseau, é importante que o conhecimento seja realmente apreendido e não que se saiba um monte de coisas, mas superficialmente: "Emílio tem poucos conhecimentos, mas os que tem são seus de verdade; nada sabe pela metade". ${ }^{31}$

\footnotetext{
${ }^{29}$ Idem, p. 108.

${ }^{30}$ Ibidem, p. $181-2$ e 221.

${ }^{31}$ Ibidem, p. 268.
} 
O princípio de utilidade deve se estender à questão da sexualidade, que deve ser abordada naturalmente; assim como para qualquer outro assunto, é preferível o silêncio a mentiras ou explicações que não estejam ao alcance da compreensão do aluno, de sua necessidade e utilidade. "Uma única mentira confirmada do mestre para o aluno arruinaria para sempre todo o fruto da educação". ${ }^{32}$

Enfim, há algumas máximas que Rousseau considera essenciais para que o homem cultive as inclinações da natureza, impedindo que o seu coração seja tocado pelos vícios da sociedade corrompida e resguardando uma das características essenciais supostas no homem natural, por exemplo, a piedade natural:

\footnotetext{
Não pertence ao coração humano colocar-se no lugar de pessoas mais felizes do que nós, mas apenas no lugar das que estão em situação mais lastimável; só lamentamos no outro os males de que não nos acreditamos isentos; a piedade que se tem pelo mal de outrem não se mede pela quantidade desse mal, mas pelo sentimento que atribuímos aos que sofrem. ${ }^{33}$
}

Assim, quando Rousseau aponta a necessidade de observar os outros e de só se colocar no lugar das pessoas que estão em situação pior, mesmo que provisoriamente, desloca-se da relação com as coisas para a relação com os homens, isto é, está considerando a idéia de vida social, de convívio com outras pessoas e, assim, começa a definir princípios que norteiam para a vida pública, para a vida política.

Em relação à educação dos filhos - ou a formação dos educandos -, afirma que os pais ou educadores - são responsáveis pela sua formação moral e política: "Um pai quando gera e sustenta seus filhos, só realiza com isso um terço de sua tarefa. Ele deve homens à sua espécie, deve à sociedade homens sociáveis, deve cidadãos ao Estado". 34

Em outras palavras, se consideramos que a educação do homem se inicia com o seu nascimento e que prossegue até a maturidade, necessitando de um olhar especial no que diz respeito ao momento em que o educando está convivendo com outras pessoas socialmente, podemos concluir que, embora seja especialmente o livro IV que aborda a educação do adolescente, a possibilidade da formação do homem integral, como pretende Rousseau ao longo

\footnotetext{
${ }^{32}$ Ibidem, p. 280.

${ }^{33}$ Ibidem, p. 290 e 292.

${ }^{34}$ Ibidem, p. 25.
} 
do Emílio, depende da educação realizada na infância, dos princípios e diretrizes exercitados desde quando a criança nasce.

Considerando essa idéia, de que a educação nos primeiros anos de vida funciona como uma espécie de alicerce para a educação até a maturidade, fica evidente a necessidade de se apontar os princípios defendidos por Rousseau no que diz respeito ao homem natural, isto é, à educação que segue a marcha da natureza, mesmo tendo como foco a adolescência. Pois é impossível defender preceitos educativos essenciais para a formação do jovem, se não se tem claro em mente o processo educacional de um modo geral, assim como é primordial apontar quais aspectos são relevantes desde a educação da criança, para a moralidade, para relacioná-la com a formação do jovem para a cidadania.

Assim, podemos evidenciar que Rousseau aponta para uma preocupação com a educação para a vida em sociedade mesmo quando não está tratando diretamente dela, e que, prevendo que seu aluno está sendo educado para estar entre os homens, desenvolve seu projeto de educação doméstica através de princípios que são fundamentais para vida em sociedade, para a vida de um homem pronto para ser parte de uma cidade, de uma sociedade política. 


\section{FORMAR O HOMEM É FORMAR O CIDADÃO}

Neste capítulo será apontado o vínculo necessário entre a educação doméstica e a educação pública em Rousseau, acentuando a idéia de que a formação do homem e do cidadão ocorre simultaneamente. Para tanto serão assinalados os pensamentos rousseaunianos ao longo do Emílio que retratam essa ligação, bem como o intuito do autor em relação à importância de se educar para a cidadania. Ao mesmo tempo, serão apontados aspectos atuais acerca da cidadania, bem como a necessidade de, frente a necessidade de se repensar esse conceito em relação à sua prática, apontarmos uma educação que viabilize a formação para a cidadania.

Rousseau não escreve explicitamente no Emílio sobre a educação pública e, logo no início do livro I afirma que por não haver pátria nem cidadão na sociedade atual "resta enfim a educação doméstica ou da natureza". ${ }^{35}$ Com isto nos dá a impressão de que não abordará a formação do cidadão.

Mas, no decorrer do livro vemos que há aspectos que se relacionam diretamente com a questão política, isto é, a formação do homem defendida pelo autor pretende que Emílio tenha um caráter bom o suficiente para que, mesmo frente à corrupção, jamais se deixe levar pelos vícios e inclinações impróprios para o perfil de um cidadão e que, dessa forma, tenha sua formação voltada para princípios próprios da vida política, como a própria necessidade de conhecer o funcionamento da sociedade civil, como vemos no livro V, desenvolvendo sua capacidade de análise acerca da vida pública.

Desse modo, é perfeitamente possível falar em formação do adolescente para a cidadania, já que Rousseau afirma, mesmo que implicitamente, que a educação de Emílio é voltada tanto para a formação do homem quanto do cidadão. Fica claro que a adolescência é o momento em que a educação política será enfatizada, já que, como afirma o autor, é quando o educando nasce para o sexo, isto é, para a convivência, que é, necessariamente, social.

Para pensarmos o que é o cidadão para Rousseau, podemos nos remeter à síntese do Contrato Social apresentada no Emílio, onde o autor defende a idéia de que, por estar prestes a se tornar um homem adulto, que deverá assumir suas responsabilidades de forma consciente e

\footnotetext{
${ }^{35}$ Ibidem, p. 13.
} 
autônoma, Emílio deve visitar as cidades, viajar para conhecer a estrutura e o funcionamento político da sociedade civil. Nesse contexto, Rousseau apresenta conceitos que considera básicos para a compreensão do que é ser cidadão e afirma que no decorrer das viagens Emílio entenderá "todas as matérias do governo, dos costumes públicos e das máximas de Estado de toda a espécie".36

Isto é, embora o autor afirme que "o direito político ainda está por nascer, e é de presumir que nunca venha a nascer" ${ }^{37}$, não descarta a importância de se conhecer a política e de se educar politicamente, pelo contrário, acredita que para viver em sociedade é preciso entender seu funcionamento, o que se dará através das observações realizadas nas viagens.

Para iniciar a síntese do Contrato Social, Rousseau apresenta a idéia de que mesmo antes de se estabelecer qualquer forma de governo ou governante, o povo já é um povo.

Isso significa afirmar que o contrato social existe anteriormente ao governo, posto que é por meio dele que o povo se forma. Assim, "o contrato social é a base de toda sociedade civil e é na natureza desse ato que se deve procurar a da sociedade que ele forma". ${ }^{38}$ Assim, para se entender qual é a natureza da sociedade civil, como ela se constitui e funciona, é preciso compreender a constituição e o funcionamento do próprio contrato social.

Para tanto, podemos considerar a definição de Rousseau, que afirma que por meio do contrato social, cada cidadão abre mão, simbolicamente, de todos os seus bens e de tudo que envolve sua própria vida em nome do bem geral, ou melhor, do bem comum que, por sua vez, inclui o seu próprio bem, já que cada indivíduo é parte do todo que compõe a sociedade contratual: "Cada um de nós põe em comum seus bens, sua pessoa, sua vida e toda a sua potência, sob a suprema direção da vontade geral, e recebemos em bloco cada membro como parte indivisível do todo". 39

De acordo com as afirmações de Nascimento ${ }^{40}$, podemos entender como o contrato social fundamenta o corpo político, considerando que a partir do seu estabelecimento, o homem, no caso enquanto cidadão, é uma parte que constitui o todo, que é a associação política:

\footnotetext{
${ }^{36}$ Ibidem, 646.

${ }^{37}$ Ibidem, p. 646.

${ }^{38}$ Ibidem, p. 650.

${ }^{39}$ Ibidem, p. 650.

${ }^{40}$ Informações concedidas pelo Prof. Dr. Milton Meira do Nascimento, no curso "Ética e Filosofia Política (O Direito Natural Moderno)", da pós-graduação em Filosofia, na FFLCH-USP.
} 
O homem civil é apenas uma unidade fracionária que se liga ao denominador, e cujo valor está em sua relação com o todo, que é o corpo social. As boas instituições sociais são as que melhor sabem desnaturar o homem, retirar-lhe sua existência absoluta para dar-lhe uma relativa, e transferir o eu para a unidade comum, de sorte que cada particular não se julgue mais como tal, e sim como parte da unidade, e só seja perceptível no todo. ${ }^{41}$

Em outras palavras, o autor afirma que cada homem, enquanto parte do povo, abre mão de seus interesses particulares para compactuar com o coletivo, isto é, seus interesses particulares estarão submetidos aos interesses de todos, representados pela vontade geral e, em contrapartida, todos terão direitos iguais dentro dessa coletividade, que é a sociedade civil. Esse ato moral se firma por meio do contrato social, como se cada indivíduo "assinasse" um termo de conscientização de que faz parte do todo e de que esse todo representa sua própria vontade, que está subordinada ao coletivo. Rousseau denomina esse coletivo de corpo político e através dele garante a cada cidadão o direito de participação nas decisões que interferem na sociedade:

No lugar da pessoa particular de cada contratante, esse ato de associação produz um corpo moral e coletivo, composto de tantos membros quantas vozes há na assembléia. Essa pessoa pública toma em geral o nome de corpo político, o qual é chamado por seus membros de Estado quando é passivo, de soberano quando é ativo e de poder quando comparado a seus semelhantes. Com relação aos próprios membros, eles recebem o nome de povo, coletivamente, e chamam-se em particular cidadãos, como membros da cidade ou partícipes da autoridade soberana, e súditos, como submetidos à mesma autoridade. ${ }^{42}$

No Emílio, Rousseau também aponta algumas características importantes para ser cidadão:

O essencial [para todo patriota] é ser bom com as pessoas com quem se vive. Fora, o espartano era ambicioso, avaro, iníquo, mas o desinteresse, a equidade, e a concórdia reinavam em sua cidade. Desconfiai desses cosmopolitas que vão procurar longe nos livros os deveres que desdenham cumprir ao seu redor. ${ }^{43}$

\footnotetext{
${ }^{41}$ ROUSSEAU, Emílio, p. 11.

${ }^{42}$ Idem, p. 650-1.

${ }^{43}$ Ibidem, p. 11.
} 
Rousseau descreve o cidadão como aquele homem que é capaz de viver bem com os seus compatriotas, isto é, na cidade em que vive. Essa convivência deve ser baseada nos critérios de solidariedade, justiça e caridade. Já que o cidadão, na concepção rousseauísta, é parte de um corpo político (o conjunto de todos os cidadãos), se ele tem atitudes solidárias, justas e caridosas com os outros membros da sociedade, também tem consigo mesmo, pois é parte dela.

Emílio, de um modo indireto, por todo Tratado de Educação de Rousseau, tem sua formação direcionada para a moralidade, mas está pronto para ser cidadão, pois possui características para essa função e está sendo educado para ocupar o papel de um homem comum, que tenha simplicidade, que não se diferencie daqueles que são mais ou menos favorecidos que ele, pois todos os homens, para o autor, devem ser considerados iguais e estar prontos para assumir qualquer papel: "Na ordem natural, sendo os homens todos iguais, sua vocação comum é a condição de homem, e quem quer que seja bem educado para tal condição não pode preencher mal as outras relacionadas com ela". ${ }^{44}$

Há momentos, no Emílio, que Rousseau parece indicar sua intenção de que educando seu aluno para ser homem, está lhe dando condições para ser cidadão. $\mathrm{O}$ autor afirma que durante o processo educativo não se deve priorizar a formação voltada para um único fim, por exemplo, para que Emílio seja apenas homem, posto que se o fizesse, estaria automaticamente impedindo-o de ser cidadão: "Tornai apropriada ao homem a educação do homem, e não ao que não é ele. Não vedes que trabalhando para formá-lo exclusivamente para uma condição o tornais inútil para qualquer outra"45, ou ainda, afirma que é função da educação formar tanto o homem quanto cidadão: "um pai, quando gera e sustenta seus filhos, só realiza com isso um terço de sua tarefa. Ele deve homens à sua espécie, deve à sociedade homens sociáveis, deve cidadãos ao Estado"46.

Assim, Rousseau preza por uma educação global, que para atingir seus objetivos, deve conglomerar a dimensão política. Isto é, a educação de Emílio, que, explicitamente, é dita exclusivamente doméstica, prepara-o também para ser cidadão, para que conheça o funcionamento político da cidade em que vive e, sobretudo, seja capaz de interagir politicamente nessa sociedade.

Embora Emílio seja educado seguindo a marcha da natureza, ou seja, tendo como princípio a conservação de virtudes através da educação negativa em relação aos vícios do estado

\footnotetext{
${ }^{44}$ Ibidem, p. 14.

${ }^{45}$ Ibidem, p. 248.

${ }^{46}$ Ibidem, p. 25.
} 
civil, não deve ser excluído do convívio social, pelo contrário, sua educação deve orientá-lo para que conheça e interaja com a sociedade política em que vive, por exemplo, conhecendo suas leis, a organização governamental etc. Não para que viva como seus concidadãos, mas com eles:

Há muita diferença entre o homem natural que vive no estado de natureza e o homem natural que vive no estado de sociedade. Emílio não é um selvagem ao ser relegado aos desertos, é um selvagem feito para morar nas cidades. É preciso que saiba encontrar nelas o necessário, tirar partido dos habitantes e viver, se não como eles, pelo menos com eles. ${ }^{47}$

Como podemos notar, ao mesmo tempo em que Rousseau descreve um processo de educação doméstica, admite ser importante que Emílio conheça as relações entre os cidadãos na vida civil: "Ora, depois de ter-se considerado através de suas relações físicas com os outros seres, de suas relações morais com os outros homens, resta-lhe considerar-se pelas relações civis com os outros concidadãos". 48

Por isso, no livro V, faz uma síntese do Contrato Social, com o intuito de que seu aluno compreenda como deve ser - mesmo que no plano do dever ser - a sociedade e a vida civil. Essas informações serão um referencial para Emílio distinguir a sociedade perfeita da corrompida, como o vemos fazer em suas viagens, e perceber que a vida ao lado de Sofia, no campo, é melhor que nas cidades, que estão totalmente degeneradas. Emílio diz ao preceptor que gostaria de permanecer no caminho da natureza, sem se deixar levar pelos vícios da sociedade degenerada, como, por exemplo, ter os seus direitos - como a liberdade - usurpados:

[quero] (...)permanecer tal como me fizeste ser e não acrescentar voluntariamente qualquer outra corrente à que me dão a natureza e as leis. Quanto mais examino a obra dos homens em suas instituições, mais vejo que, de tanto quererem ser independentes, eles se tornam escravos, e que gastam a própria liberdade em vãos esforços para garanti-la. ${ }^{49}$

Embora Rousseau afirme no início do Emílio que como não há mais a instituição política, não é possível formar o cidadão, restando a formação do homem, e que não é possível formar os dois ao mesmo tempo: "é preciso optar entre fazer um homem ou um cidadão, pois não se pode

\footnotetext{
${ }^{47}$ Ibidem, p. 265.

${ }^{48}$ Ibidem, p. 643.

${ }^{49}$ Ibidem, p. 667.
} 
fazer os dois ao mesmo tempo" 50 , em outro momento do texto diz que para que se possa entender a sociedade e os homens, é necessário estudá-los relacionando-os entre si, pois não é possível separar a política da moral, posto que ambas se correlacionam na formação humana: "é preciso estudar a sociedade pelos homens, e os homens pela sociedade; quem quiser tratar separadamente a política e a moral nada entenderá de nenhuma das duas". ${ }^{51} \mathrm{E}$, ainda, afirma que a educação doméstica tem como conseqüência a educação pública:

Como se o amor que temos pelo próximo não fosse o princípio do amor que se deve ao Estado! Como se não fosse pela pequena pátria que é a família que o coração se liga à grande! Como se não fossem o bom filho, o bom marido, o bom pai que fizessem o bom cidadão. ${ }^{52}$

No livro I do Emílio, Rousseau justifica sua opção em formar o homem porque a “instituição pública não existe mais, e não pode mais existir, já que onde não há mais pátria não pode haver cidadãos" 53 , mas no livro V afirma que "quem não tem uma pátria tem pelo menos um país" ${ }^{54}$, perguntando a Emílio onde está o homem de bem que nada deve à sua nação. Logo, podemos concluir que a educação doméstica, que forma o homem de bem, caminha junto com a educação pública, que forma o bom cidadão, e que é uma formação necessária para que o país tenha uma boa estrutura política, bem como uma participação consciente e crítica dos cidadãos.

Essa conclusão também pode ser pensada a partir do prefácio que Rousseau escreve ao Emílio, "para mim, basta que em toda parte onde nasceram homens se possa fazer deles o que proponho; e que, tendo feito deles o que proponho, se tenha feito o que há de melhor, tanto para eles próprios [vida particular] quanto para os outros [vida pública]". ${ }^{55}$ Quando há o desejo de educar o homem que seja bom para ele mesmo e para os outros, educa-se para vida em sociedade, para a cidadania.

Este desejo de se educar para vida social também pode ser notado quando Rousseau afirma que "nascemos, por assim dizer, duas vezes: uma para existir, outra para viver; uma para a espécie, outra para o sexo"56, e logo em seguida: "o homem, em geral, não foi feito para

\footnotetext{
${ }^{50}$ Ibidem, p. 10.

${ }^{51}$ Ibidem, p. 309.

52 Ibidem, p. 449.

${ }^{53}$ Ibidem, p. 12.

${ }^{54}$ Ibidem, p. 670.

${ }^{55}$ Ibidem, p. 06.

${ }^{56}$ Ibidem, p. 271.
} 
permanecer sempre na infância" ${ }^{57}$. Isto é, se o homem foi feito para crescer, para se tornar adolescente e depois adulto e se, na adolescência, nasce para o sexo, ou seja, para se relacionar com outras pessoas, para o que a sexualidade sinaliza, fica evidente que nasce para conviver com os outros, para viver em sociedade.

Além disso, na introdução do Emílio, Michel Launay afirma que "a primeira versão da obra começava com um desenvolvimento sobre a educação pública",58, daí deduzirmos que ele não excluiria esse projeto. E, ainda, a relação entre educação e política também fica explícita se lembrarmos que Rousseau queria publicar o Emílio e o Contrato Social ao mesmo tempo. E, mais do que o desejo de que fossem publicados juntos, para Assmann fica claro que:

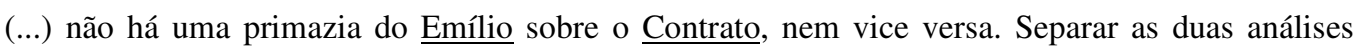
equivaleria a perder o chão sobre o qual foram produzidas. A relação é complexa quando se lêem ambas as obras na perspectiva de que urge formar o homem e o cidadão, e de que humanidade e cidadania não se identificam nem se complementam, e nem se quer simplesmente se opõem. $\mathrm{O}$

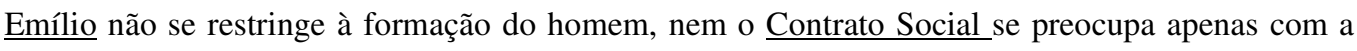
formação do cidadão. Todo homem é formação social: os homens instituem a sociedade e esta é instituída e institui os homens. ${ }^{59}$

De qualquer forma, podemos ver que, apesar de Rousseau se preocupar explicitamente com a formação do homem no Emílio, em seu texto sobre Educação em Considerações Sobre o Governo da Polônia fica evidente que a educação deve formar o cidadão:

É a educação que deve dar às almas a forma nacional e dirigir de tal forma suas opiniões e seus gostos, que elas sejam patriotas por inclinação, por paixão, por necessidade. Uma criança, abrindo os olhos, deve ver a pátria e até à morte não deve ver mais nada além dela. ${ }^{60}$

Se a criança deve amar a pátria desde o nascimento e o Emílio aborda a educação também desde o nascimento, fica evidente que Rousseau acredita que há a possibilidade da formação simultânea do homem e do cidadão ao longo do processo educativo, pois embora afirme que, na infância, esteja preocupado com a formação do homem, aponta para a idéia de que é por meio

\footnotetext{
${ }^{57}$ Ibidem, p. 271.

${ }^{58}$ Ibidem, p. XX.

${ }^{59}$ ASSMANN, p. 10.

${ }^{60}$ ROUSSEAU, Considerações, p. 277.
} 
dessa educação que começa com o nascimento que visa também o envolvimento e o respeito em relação ao país, e que, embora seja pela inexistência da pátria e do cidadão na sociedade atual que a educação pública perde seu papel, ainda existe a necessidade e a opção da educação doméstica, que, como vemos, também se direciona para formação política.

Em outras palavras, é possível afirmar que Rousseau acredita na possibilidade de formar o homem e o cidadão, mas, ao mesmo tempo, é necessário considerar que, simultaneamente, descrevia a melhor cidade, no Contrato Social, isto é, a formação mais adequada da humanidade se direciona para uma instituição política que também representa o plano de um lugar de tanta qualidade que funcione como um referencial, como vemos no Contrato, seu cidadão tinha um lugar definido, uma cidadania que mesmo hipoteticamente, foi conceituada considerando uma forma adequada de organização social, que possibilitaria a cada indivíduo sentir-se parte do todo.

Em outras palavras, Rousseau desenvolveu tanto um projeto de uma educação que fosse referência quanto de sociedade:

(...) uma forma de associação que defenda e proteja a pessoa e os bens de cada associado com toda a força comum, e pela qual cada um, unindo-se a todos, só obedece contudo a si mesmo, permanecendo assim tão livre quanto antes (...) [onde] cada um de nós põe em comum sua pessoa e todo o seu poder sob a direção suprema da vontade geral, e recebemos, enquanto corpo, cada membro como parte indivisível do todo. ${ }^{61}$

Para Rousseau, submeter-se à vontade geral é uma condição necessária para que a constituição da sociedade política seja viabilizada, pois é a partir dela que todos os cidadãos têm os seus direitos garantidos, sem preocupar-se em ser injustiçado socialmente ou economicamente enquanto indivíduo, pois cada indivíduo está no todo: "Pouco lhe importa a quem cabe maior felicidade na divisão, contanto que concorra para a maior felicidade de todos: este é o primeiro interesse do sábio depois do interesse privado, pois cada qual é parte de sua espécie e não de outro indivíduo". 62

Ou ainda, para pensarmos a conceituação de uma organização política que funcione bem por meio de um autor mais recente, vemos que Pinsky ${ }^{63}$ afirma que a comunidade deve ser entendida como um lugar onde os cidadãos convivem e compartilham responsabilidades

\footnotetext{
${ }^{61}$ ROUSSEAU, Contrato Social, p. 38-9.

${ }^{62}$ ROUSSEAU, Emílio, p. 336.

${ }^{63}$ Jaime Pinsky é historiador, doutor pela USP e professor titular pela Unicamp.
} 
respeitando o bem coletivo: "as várias correntes do socialismo humanista entendem que os cidadãos são sócios do mesmo empreendimento e companheiros da mesma comunidade: nenhum deles pode tirar proveito do outro, mas todos devem agir pelo bem comum, numa igualdade básica de condição social e econômica". ${ }^{64}$

A cidadania descrita por Rousseau, lembrando que se trata de uma descrição no plano do dever ser, é bastante diferente daquela que podemos visualizar na realidade atual, posto que esta última não pressupõe uma associação de pessoas que doam sua vida em nome do todo ou onde prevaleça a vontade geral em nome do bem estar coletivo.

Ou ainda, numa tentativa de aproximar o conceito de cidadania da nossa realidade, podemos notar que Pinsky afirma que se trata de ter direitos e deveres que implicam a participação direta ou indireta nas decisões referentes à organização política, como respeitar as leis, pagar impostos etc:

\footnotetext{
Ora, cidadania enfaixa uma série de direitos, deveres e atitudes relativos ao cidadão, aquele indivíduo que estabeleceu um contrato com seus iguais para a utilização de serviços em troca de pagamento (taxas e impostos) e de sua participação, ativa ou passiva, na administração comum. Por essa definição (mesmo apressada e meramente funcional), se vê que cidadania pressupõe, sim, o pagamento de impostos, mas também a fiscalização de sua aplicação; o direito a condições básicas de existência (comida, roupa, moradia, educação e atendimento de saúde) acompanhado da obrigação de zelar pelo bem comum. ${ }^{65}$
}

Isto é, atualmente no Brasil, embora se saiba que ser cidadão significa ter direitos básicos, mas, também, deveres em relação ao coletivo, é possível notar que, em vários casos, a visão que se tem de cidadania se restringe aos benefícios do cidadão em relação aos seus direitos, sem a necessidade de se comprometer com a realização dos deveres. Como afirma Pinsky, para ser cidadão não basta votar, é preciso estar presente de fato no cotidiano da cidade, é preciso cuidar da comunidade em que se vive e primar pelo bem comum:

Exigir direitos é parte da cidadania, mas respeitar os contratos sociais é sua contrapartida. Talvez por não fazermos a nossa parte ou não termos a consciência de pertencer a um coletivo é que somos tão condescendentes com irregularidades que acabam prejudicando todos. E o fato de mantermos a

\footnotetext{
${ }^{64}$ PINSKY, p. 11.

${ }^{65}$ Idem, p. 18-9.
} 
maioria da população sem os direitos básicos de cidadania nos impede de construir a Nação-cidadã que arrotamos desejar. ${ }^{66}$

É bastante comum, nos dias atuais, vermos situações em que alguns cidadãos estão totalmente descomprometidos com o bem estar coletivo ou com o cumprimento das leis existentes na sociedade, desde que se possa tirar algum proveito particular, como aponta Pinsky:

Devido à nossa formação histórica, em que a cultura bacharelesca sempre teve enorme influência, somos antes súditos preocupados com a letra da lei do que cidadãos responsáveis pelo espírito dela. Consideramos sinal de esperteza encontrar "saídas" na legislação que nos permitam burlá-la e para isso nos cercamos de profissionais pagos a peso de ouro. Burlar a lei de forma legal (por mais contraditória que possa parecer a fórmula) é uma especialidade para a qual pessoas são treinadas, o mercado está aberto e existe até uma legitimação social. Trata-se do reconhecimento oficial da atividade anticidadã, se aceitarmos a idéia de que a legislação existe para normatizar a relação entre iguais. É a consagração das famosas duas categorias de cidadãos, os iguais e os mais iguais... ${ }^{67}$

A idéia de direitos coletivos, desde a época retratada por Rousseau, é uma sociedade de direitos quiméricos, na qual permite-se a opressão do mais forte em relação ao mais fraco, rompendo com o princípio de igualdade prescrito pela natureza:

\begin{abstract}
Há no estado civil uma igualdade de direito quimérica e vã, porque os meios destinados a mantê-la servem eles próprios para destruí-la, e a força pública somada ao mais forte para oprimir o fraco rompe a espécie de equilíbrio que a natureza colocara entre eles. Desta primeira contradição decorrem todas as que se observam entre a aparência e a realidade na ordem civil. Sempre a multidão será sacrificada ao menor número, e o interesse público ao interesse particular; sempre os nomes enganosos de justiça e subordinação servirão de instrumento para a violência e de arma para a iniqüidade. ${ }^{68}$
\end{abstract}

Isto é, a definição dada por Rousseau e retomada por Pinsky cabe no plano do dever ser, não no plano real. Daí ser necessário cuidar para que a leitura do Emílio seja realizada tendo em vista que se trata de uma obra que aponta um projeto de educação, uma espécie de escala na qual poderíamos obter um referencial para o processo educativo, mas não algo realizável, como um

\footnotetext{
${ }^{66}$ Ibidem, p. 19.

${ }^{67}$ Ibidem, p. 48-9.

${ }^{68}$ ROUSSEAU, Emílio, p. 310.
} 
manual de ações pedagógicas. Assim como a cidade descrita por Rousseau no Contrato Social não é passível de realização, seja onde for, inclusive no Brasil, posto que é preciso evidenciar que Rousseau não apontava suas idéias para uma sociedade real, mas princípios norteadores para termos uma referência acerca da constituição de uma organização política.

No que diz respeito a idéia de escala, Rousseau afirma que funciona como uma espécie de régua, onde se tem o nível máximo onde se pode chegar - por exemplo, a melhor educação e a melhor cidade possível - e, abaixo dele, medidas que são relativas ao melhor possível: "Antes de observar, é preciso estabelecer regras para as observações, é preciso fabricar uma escala para nela marcar as medidas que se tiram. Nossos princípios de direito político [no caso, o Contrato Social] são essa escala. Nossas medidas são as leis políticas de cada país" ${ }^{6}{ }^{9}$

Apontar a idéia de que tanto o Emílio quanto o Contrato Social funcionam como uma escala, como afirma o próprio Rousseau, por meio da qual se possa medir as características da educação e da sociedade em relação a sua eficácia é essencial para que se evite considerar essas obras como projetos realizáveis ou manuais.

Então, para que se possa pensar a educação voltada para a cidadania, como vemos implicitamente no Emílio, é preciso considerar os pensamentos políticos do autor, para tê-los como um referencial no que diz respeito à formação do cidadão.

Para começarmos tal investigação, é interessante pensarmos, como aponta Nascimento ${ }^{70}$, na idéia de direito - enquanto lei -, pois independentemente de estar se direcionando a uma cidade real ou hipotética, o conceito de direito é algo fundamental para a cidadania e para pensarmos os ideais apresentados no Contrato e em qualquer Legislação.

A princípio é interessante notar que, para Rousseau, o homem, a partir da idade da razão, isto é, da maturidade, é capaz e livre para se submeter ou não às leis estabelecidas pelos seus ancestrais na sociedade em que vive. Em outras palavras, o homem adulto é capaz de analisar as leis da sociedade em que vive, ponderando suas opiniões em relação às mesmas para decidir se estão ou não de acordo com o que considera viável e tem a liberdade de decidir se quer viver naquela comunidade política ou se prefere deixar o país:

\footnotetext{
${ }^{69}$ Idem, p. 648.

${ }^{70}$ As reflexões a seguir foram elaboradas a partir das informações concedidas pelo Prof. Dr. Milton Meira do Nascimento, no curso "Ética e Filosofia Política (O Direito Natural Moderno)”, da pós-graduação em Filosofia, na FFLCH-USP.
} 
Pois, por um direito que ninguém pode ab-rogar, cada homem, ao tornar-se maior e senhor de si, torna-se também senhor da possibilidade de renunciar ao contrato pelo qual se liga à comunidade, deixando o país em que ela se estabeleceu (...) pelo direito rigoroso, todo homem nasce livre, arcando com as responsabilidades, em qualquer lugar que nasça, a menos que se submeta voluntariamente às leis para adquirir o direito de ser protegido por elas. ${ }^{71}$

Considerando ainda as afirmações de Nascimento, Rousseau acredita que a única maneira de fazer com que os homens obedeçam às leis é através da participação em sua elaboração ou por consentimento. As ações dos governantes só podem estar em concordância com as necessidades dos cidadãos - representadas pela vontade geral - a partir do momento em que eles estão conscientes em relação às leis e consentem com elas, firmando, assim, um contrato social: "Na grande família, onde os membros são naturalmente iguais, apenas a convenção pode fundamentar a autoridade política puramente arbitrária quanto à sua instituição, e o magistrado só pode comandar os outros em virtude das leis". ${ }^{72}$

No entanto, a possibilidade de se efetivar a cidadania e a constituição de uma organização política no Brasil depende, principalmente, de políticas públicas que direcionem a educação para a formação do cidadão, pois atualmente os jovens não têm noção de que viver em sociedade pressupõe pensar coletivamente, pelo contrário, o que vemos nas escolas é a ausência desse processo educativo que forme o cidadão. Caso contrário, perpetuaremos o egocentrismo, que deveria ser simplesmente uma característica de determinada fase da vida, a infância, para a vida toda, como demonstra Pinsky, em suas observações sobre algumas situações em que alguns membros da sociedade - já que não é possível chamar de cidadão - têm suas atitudes voltadas simplesmente para o próprio bem, como exemplifica com o caso do "vizinho":

E o que dizer do vizinho do prédio, principalmente o de cima? Generoso, nosso vizinho de cima quer dividir conosco seu cotidiano e suas emoções. Quando chega em casa se anuncia batendo as portas sem evitar tirar suas botas de vaqueiro ou saltos altos, de modo a ouvirmos seu tropel através da fina casca de concreto e malfadado carpete de madeira. Para que possamos compartilhar suas andanças pela sala e a corrida do seu pimpolho atrás da bola, evita a forração (...) Ele gosta mesmo é de uns tamancos ortopédicos que nos comunicam o momento exato em que vai esvaziar a bexiga ou atacar a geladeira em plena madrugada. Ao pedirmos, humildemente, um pouco de silêncio, uma vez que costumamos escrever em casa, ele nos comunica que nossos apartamentos são

\footnotetext{
${ }^{71}$ ROUSSEAU, Emílio, p. 643.

${ }^{72}$ ROUSSEAU, Discurso sobre a Economia Política, p. 22.
} 
residenciais e não de escritório (...) Orgulhoso por sua façanha de comprar um apartamento (...) o "vizinho" é a personificação do neoliberal feliz consigo mesmo e seguro de que consideração pelo próximo é coisa de fraco. ${ }^{73}$

Se considerarmos que a sociedade atual é constituída pelos inúmeros "vizinhos" com os quais convivemos diariamente, vemos que estamos longe da medida mínima da escala em relação à sociedade proposta pelo Contrato Social, já que quando os interesses particulares se sobressaem em relação ao bem comum, é impossível falar em cidadania, em participação política ou em vontade geral:

A vontade dessas sociedades particulares tem sempre duas relações: para os seus próprios membros, é uma vontade geral, para o conjunto da sociedade, uma vontade particular, freqüentemente reta, no primeiro caso, e viciosa, no segundo. Qualquer um pode ser ao mesmo tempo um padre devoto, um soldado valente ou um médico zeloso e um mau cidadão. ${ }^{74}$

Como afirma Nascimento $^{75}$, com a ausência da vontade geral e o crescimento desmesurado da vontade particular, as leis existem apenas no papel, enquanto letra morta, posto que os interesses são tão individualistas, que não importa garantir os mesmos direitos a todos os cidadãos. Desse modo, a reivindicação por qualquer direito, como à liberdade, perde a força que poderia adquirir através da vontade geral: "É em vão que aspiramos à liberdade sob a salvaguarda das leis. Leis! Onde elas existem e onde são respeitadas? Em toda parte só viste reinar sob esse nome o interesse particular e as paixões dos homens". ${ }^{76}$

Para confirmar a inexistência das leis enquanto garantia de direitos, como a igualdade, entre os homens, podemos ainda contar com a afirmação de Nascimento acerca da idéia de que frente a interesses particulares a cidadania é uma utopia, posto que não é possível haver leis que privilegiem determinadas classes ou determinados membros da sociedade. E se as leis não são gerais, tornam-se privilégios, e acentuam a ignorância em torna do conceito de coletividade:

(...) os direitos iguais para todos acabam por se transformar numa verdadeira quimera. A cidadania

se faz ilusão. Aparentemente, todos somos iguais, livres, proprietários, com todos os direitos

\footnotetext{
${ }^{73}$ PINSKY, p. 67.

${ }^{74}$ ROUSSEAU, Discurso sobre a Economia Política, p. 26.

${ }^{75}$ No curso já mencionado.

${ }^{76}$ ROUSSEAU, Emílio, p. 669.
} 
garantidos. Como são direitos de um homem abstrato, de fato, nem todos são livres, não possuem os mesmos direitos e menos ainda a propriedade. Só a alguns privilegiados é facultada a possibilidade de gozar plenamente desses direitos. Quando estes se transformam em privilégios, rompe-se a igualdade e retornamos ao patamar de uma condição na qual vale muito bem a expressão salve-se quem puder. ${ }^{77}$

No caso brasileiro propriamente dito, também cabe bem a idéia de "salve-se quem puder", já que nos parece que não há leis nem para o próprio Estado! E, muitas vezes, podemos até nos perguntar se elas existem... Parece impossível falar em leis quando a atual realidade é de tanta desigualdade, assim como corrupção:

Assim, quando os interesses particulares se voltam contra o interesse geral que não é mais o de um indivíduo, os vícios públicos têm mais força para enfraquecer as leis do que as leis para reprimir os vícios; de modo que, ao final, a corrupção do povo e dos chefes alcança o governo, por mais sábio que ele seja: o pior de todos os abusos é o de somente obedecer aparentemente às leis para melhor desrespeitá-las com total segurança. Logo as melhores leis tornam-se as mais funestas e nesse caso seria cem vezes melhor que não existissem; esse é um recurso possível quando não restar mais nada. $^{78}$

E então, considerando as idéias de Nascimento $^{79}$, se não há direitos de fato, nós que não temos a lei supostamente garantida, deixamos de ser cidadãos por não termos nossos direitos garantidos como afirma a letra da lei? Mas quem é o cidadão rousseauniano afinal? Como vemos no Emílio: "Com relação aos próprios membros, eles recebem o nome de povo, coletivamente, e chamam-se em particular cidadãos, como membros da cidade ou partícipes da autoridade soberana, e súditos, como submetidos à mesma autoridade". 80

Ou ainda, se nos remetemos a um conceito relacionado à Antiguidade, que condiz com a teoria rousseauísta, "o pólites da Grécia Antiga, que os romanos traduziram por cives, era propriamente o sócio da cidade, aquele que possuía direitos e deveres comuns a todos os cidadãos, e participava efetivamente das decisões coletivas". ${ }^{81}$

\footnotetext{
${ }^{77}$ NASCIMENTO, p. 125.

${ }^{78}$ ROUSSEAU, Discurso sobre a Economia Política, p. 32-3.

${ }^{79}$ Ainda no curso sobre Ética e Filosofia Política.

${ }^{80}$ ROUSSEAU, Emílio, p. 651.

${ }^{81}$ PINSKY, Cidadania e educação, p. 12.
} 
Quer dizer que as definições de cidade e de cidadão, em Rousseau, são conceitos que andam em mão dupla, isto é, se a cidade é a associação de homens em nome de um objetivo comum, que se manifesta enquanto vontade geral, cidadão é cada homem desta associação, que abre mão de seus interesses particulares em nome do pacto político, regido pela vontade geral, que é fundamental.

Daí, considerando, como vimos no Discurso, que a desigualdade foi instituída pelas ações dos homens, é de responsabilidade deles, frente a uma sociedade degenerada, a formação do homem e do cidadão, para que seja possível solucionar o problema da ausência de humanidade e política, isto é, é preciso formar o homem e o cidadão para que possamos nos colocar em algum grau da escala de medidas proposta por Rousseau por meio do Contrato, como afirma Assmann:

\footnotetext{
É neste contexto geral que se urde a reflexão de Rousseau: o conflito entre humanidade e cidadania no homem se dá concretamente numa sociedade que é marcada pela desigualdade, pela miséria de muitos. Tal desigualdade é da exclusiva responsabilidade dos homens. Sendo assim, são os homens - e só eles - que a podem e devem eliminar, pedagógica e politicamente. Se a causa do mal é a política, a solução também o é. A solução não virá de Deus ou dos deuses, nem da natureza, mas dos homens. Corajosamente, Jean-Jacques estabelece o fim do predomínio da teodicéia e o início do primado da política, pela construção duma "vontade geral". ${ }^{82}$
}

Assim como vemos na idéia de sociedade contratual apontada por Rousseau, para Mazzuoli $^{83}$, o conceito de cidadão se constitui historicamente, posto que teve influência da Declaração de 1948 e da Conferência de Viena de 1993, garantindo às pessoas que habitam em determinada sociedade, que tenham seus direitos assegurados pelo Estado, assim como a obrigação de cumprir os deveres em relação ao próprio Estado:

(...) em face do processo de internacionalização dos direitos humanos, iniciado com a proclamação da Declaração Universal de 1948 e reiterado na Segunda Conferência de Viena, em 1993, cidadãos, hoje, são todos aqueles que habitam o âmbito da soberania de um Estado e desse Estado têm assegurados, constitucionalmente, direitos e garantias fundamentais mínimos, com a pertinência de existirem, igualmente, deveres, que, obrigatoriamente, devem ser cumpridos. ${ }^{84}$

\footnotetext{
${ }^{82}$ ASSMANN, p. 10.

${ }^{83}$ Valério de Oliveira Mazzuoli foi mestrando em Direito na Unesp, professor de Direito na Faculdade de Direito de Franca, de Presidente Prudente e na UNOESTE.

${ }^{84}$ MAZZUOLI, p. 99.
} 
Desde Rousseau até os dias atuais, pensar em cidadania é praticamente pensar em política, pois nas relações políticas há uma espécie de compromisso (contrato) firmado entre as partes que, no caso, são o Estado e os cidadãos, como podemos notar no caso do Brasil, onde esse contrato é firmado por meio da democracia representativa, isto é, os cidadãos elegem seus representantes, que devem governar tendo em mente o compromisso de garantir a qualidade de vida dos cidadãos.

Mas é importante ressaltar que o Estado Brasileiro, que garante os direitos e deveres constituintes do conceito de cidadão, o faz burocraticamente, como no caso da educação, pois em sua Legislação, há a garantia de uma educação de qualidade, que forme o educando para cidadania, o que não ocorre na prática, o que não se efetiva para todos os cidadãos, isto é, aqueles que estão no âmbito estatal.

Rousseau descreve os princípios de um plano de formação política que poderia nortear a prática de qualquer país, como o Brasil, por exemplo, que só aponta esses princípios como objetivos, sem qualquer tentativa real de viabilizar o processo. Para ele, "a arte do mestre consiste em nunca deixar que suas observações se entorpeçam sobre minúcias que não se relacionam com nada, mas em aproximá-lo continuamente das grandes relações que um dia deverá conhecer para bem julgar sobre a boa e a má ordem da sociedade civil". 85

Outros pensadores também apontam alguns indícios de como desenvolver o que se espera de uma educação para cidadania, se considerarmos, como afirma Mazzuoli, que cidadania:

(...) consiste na consciência de participação dos indivíduos na vida da sociedade e nos negócios que envolvem o âmbito de seu estado, alcançados, em igualdade de direitos e dignidade, através da construção da convivência coletiva, com base num sentimento ético comum, capaz de torná-los partícipes no processo do poder e garantir-lhes o acesso ao espaço público, pois democracia pressupõe uma sociedade civil forte, consciente e participativa. A cidadania, nessa ordem de idéias, é o "direito a ter direitos", para se falar como Hannah Arendt. Ou seja, é o espaço político onde toda e qualquer manifestação reivindicatória de direitos se exterioriza; é o direito de lutar por mais direitos, só conseguido, através da politização da sociedade, condição fundamental para o acesso ao espaço público. ${ }^{86}$

\footnotetext{
${ }^{85}$ ROUSSEAU, Emílio, p. 241.

${ }^{86}$ MAZZUOLI, p. 107-8.
} 
Enfim, podemos falar na existência das leis, dos direitos, dos deveres e da cidadania, mas apontando para a idéia de que, na realidade brasileira, talvez por termos uma democracia relativamente recente, esses fatores estão em processo de construção, ou seja, ainda não temos a efetivação das leis ou a garantia dos direitos básicos aos cidadãos, mas apenas alguns benefícios próprios de um regime democrático, como a possibilidade de participação política e, assim, a chance de reflexão acerca da efetiva formação de cidadãos. Mas como possibilitar a educação para a cidadania se não há conscientização política?

Em outras palavras, há uma contradição em torno da idéia de educação para a cidadania frente à sociedade que temos, pois os direitos, os deveres e as leis reais só poderiam existir se a verdadeira cidadania existisse e esta, por sua vez, depende da existência da cidade enquanto corpo político - se lembrarmos, pólis, política, participação direta e consciente nas decisões que interferem na vida em sociedade, participação na elaboração e execução das leis -, mas não há cidadãos, menos ainda em relação à Legislação, que prevê uma "sociedade geral do gênero humano", enquanto agregado de individualidades e não uma união de cidadãos.

Assim, temos a impressão de que as leis não têm funcionalidade, posto que a própria população não está consciente dos direitos e deveres inerentes ao cidadão, e, ainda, podemos notar em alguns governos, que determinados políticos - que deveriam representar a vontade do povo e priorizar sua qualidade de vida -, se aproveitam dessa ignorância do povo para "utilizar" as leis em benefício de seus interesses pessoais, como vemos nos casos de corrupção existentes na realidade brasileira. Como afirma Rousseau:

Quanto mais se multiplicam as leis, mais elas se tornam desprezíveis: e todos que são instituídos vigilantes serão apenas novos infratores destinados a dividir com os antigos, ou a fazer à parte sua pilhagem. Rapidamente o preço da virtude torna-se o do roubo: os homens mais vis passam a ser os que têm mais crédito; os mais nobres são os mais desprezados; sua infâmia choca-se com sua dignidade e as honrarias se desonram. Se compram os votos dos chefes ou a proteção das mulheres, é por sua vez para vender a justiça, o dever e o Estado; e o povo, que não está a par de que seus vícios são a primeira causa de seus males, murmura e clama entre gemidos: "Todos os meus males resultam daqueles a quem pago para me protegerem deles". ${ }^{87}$

Desse modo, é possível pensar que, para que os direitos básicos sejam garantidos, é necessário pensar tanto na formação política quanto moral dos educandos, como possibilidade de

\footnotetext{
${ }^{87}$ ROUSSEAU, Discurso sobre a Economia Política, p. 32.
} 
instituir um comportamento mais ético e voltado para o bem estar coletivo. Assim, teríamos uma oportunidade de reflexão e participação políticas mais conscientes em relação à exigência dos nossos direitos básicos, assim como de nossos deveres e, conseqüentemente, a constituição de uma sociedade política.

Para vermos uma educação voltada para cidadania, seria necessária uma reforma política e educacional no país, na qual os educadores pudessem assumir a responsabilidade por uma prática pedagógica, onde o exemplo e o objetivo fosse:

\footnotetext{
Vestir a camisa de "cidadão", ter consciência dos direitos e deveres constitucionalmente estabelecidos e participar ativamente de todas as questões que envolvem o âmbito de sua comunidade, de seu bairro, de sua cidade, de seu Estado e de seu país, não deixando passar nada, não se calando diante do mais forte, nem subjugando o mais fraco [uma das máximas expostas no Emílio]. Saber que se pertence a uma determinada comunidade e qual o motivo por que a ela se pertence; reivindicar e lutar pelo direito e saber por que se luta ou reivindica. (...) Ter o orgulho de saber que a sua dignidade foi alcançada pela sua luta. Ser cidadão e ter o orgulho de ser digno. ${ }^{88}$
}

Nesse sentido, educar para cidadania é uma prática pedagógica que envolve a atitude dos educadores, o envolvimento com o corpo político, isto é, como Rousseau afirma: "antes de ousar empreender a formação de um homem, é preciso ter-se feito homem; é preciso ter em si o exemplo que se deve propor ${ }^{\circledR}$, , da mesma forma, podemos considerar que antes de ensinar a ser cidadão, é necessário ser cidadão, o que pressupõe um comprometimento com a educação, especialmente por parte dos educadores, que estão em contato direto com os educandos praticamente todos os dias.

Dessa forma, fica evidente que há necessidade de investimentos na formação e condições dignas de trabalho na educação, que é preciso investir na formação para a cidadania dos próprios educadores, que muitas vezes têm a qualidade do seu trabalho comprometida devido à adversidade da realidade em que lecionam. Isto é, o educador deve ter a consciência de sua responsabilidade na formação dos educandos para que estes, no mínimo, conheçam o funcionamento da sociedade civil em que vivem e, assim, possam desempenhar bem seu papel enquanto parte desse todo, com consciência e participação política; assim como as políticas públicas devem ser direcionadas para oferecer condições dignas de realização dessa prática.

\footnotetext{
${ }^{88}$ MAZZUOLI, p. 110-1.

${ }^{89}$ ROUSSEAU, Emílio, p. 93.
} 
É claro que, considerando a realidade atual acerca da educação, não se trata de uma tarefa simples, pelo contrário. Mas é preciso pensar que, analogamente à definição de corpo político, que só se constitui com a soma de cada indivíduo e só se legitima com o cumprimento da vontade geral, o comprometimento das partes envolvidas no processo educativo, como o governo, os profissionais da educação, a comunidade escolar etc, pode legitimar a luta pelo sucesso da educação e a efetivação desse processo em busca da sua eficácia.

Enfim, considerando que Rousseau faz uma síntese do Contrato Social ao final do Emílio, é evidente que se preocupa com a formação para vida política, principalmente porque afirma que “é seguindo o fio dessas pesquisas que chegaremos a saber quais são os deveres e os direitos do cidadão e se podemos separá-los uns dos outros; o que é pátria, em que ela consiste precisamente e como cada um pode saber se tem ou não uma pátria." 90 Essa pesquisa a que ele se refere engloba "todas as matérias do governo, dos costumes públicos e das máximas de Estado de toda espécie" ${ }^{91}$, isto é, tudo em torno dos direitos políticos, como descrito no próprio Contrato Social.

Desse modo, se é evidente que o autor se preocupa com a educação voltada para a cidadania, podemos afirmar que é possível definir princípios que orientem a formação do adolescente para ser cidadão. Essa possibilidade se viabiliza através da reflexão em torno de preceitos desenvolvidos no Emílio que são parâmetros para a formação do homem e do cidadão e, sobretudo, da apropriação das reflexões elaboradas por Rousseau quanto à responsabilidade de se educar para moralidade e para política, acentuando a idéia de que "quem quiser tratar separadamente a política e a moral nada entenderá de nenhuma das duas". ${ }^{22}$

\footnotetext{
${ }^{90}$ Idem, p. 659.

${ }^{91}$ Ibidem, p. 646.

${ }^{92}$ Ibidem, p. 309.
} 


\section{- III -}

\section{O ADOLESCENTE E A EDUCAÇÃO - CONTRAPONTOS ENTRE ROUSSEAU E A ATUALIDADE}

Neste capítulo serão apontadas algumas idéias de Rousseau acerca da adolescência, especialmente no que diz respeito aos aspectos psicológicos dos jovens e de como a sua educação deve ser orientada. O perfil desse jovem será relacionado com os adolescentes atuais, numa tentativa de delimitar as características comuns, assim como algumas intervenções educativas cabíveis a partir da concepção de educação do filósofo. Também serão apontadas algumas percepções dos jovens acerca da importância da política em suas vidas, para demonstrar a necessidade de se educar politicamente, para a cidadania.

Rousseau determina que a adolescência começa quando o jovem é inserido na vida social, ou seja, quando vai deixar de conviver tanto no núcleo familiar - com o preceptor e a ama-deleite, no caso do Emílio - e passa a se relacionar socialmente com as pessoas da sua comunidade, do local onde vive. Essa convivência se dará por meio do desenvolvimento da sexualidade, que leva o adolescente a buscar a companhia de outras pessoas, no caso, do sexo oposto: "Nascemos, por assim dizer, duas vezes: uma para existir, outra para viver; uma para a espécie, outra para o sexo". 93

Isto é, a partir do momento em que será inserido na sociedade, através do relacionamento com os outros, que Emílio começa a viver uma vida humana propriamente dita. Daí a importância da adolescência, que é o momento em que o jovem começa de fato a viver, a ter um papel na sociedade, que vai além de sua simples existência.

Devido a esse valor dado à juventude, é que podemos reiterar a necessidade de um olhar especial para a educação de adolescentes, para esse momento no qual o jovem sofrerá transformações físicas e psíquicas, necessitando de se adaptar a essa nova realidade, especialmente em relação à formação de seu caráter, de seus próprios valores, mesmo que a partir daqueles ensinados pelo educador.

\footnotetext{
${ }^{93}$ Ibidem, p. 271.
} 
E considerando que é um momento essencial por deixar suas influências - positivas ou negativas - pelo resto da vida, é preciso cuidar para que a passagem da infância para a adolescência ocorra da forma mais natural possível, respeitando o ritmo de desenvolvimento do jovem: "Mas o homem, em geral, não foi feito para permanecer sempre na infância. Dela sai no tempo indicado pela natureza, e esse momento de crise, embora muito curto, tem longas influências". 94

Becker afirma que a juventude é um momento precioso, pois a crise é o sentido da adolescência, é o período que traz a possibilidade de contestar os valores vigentes na sociedade, assimilando-os ou rejeitando-os e que, assim, o adolescente constrói a sua própria identidade, a personalidade que terá enquanto adulto autônomo:

\footnotetext{
E numa sociedade na qual não há divergência, na qual se exige cada vez mais conformidade, onde o diferente é perigoso, doente ou indecente, e os conflitos não são avaliados pelo seu potencial de crescimento, mas temidos como distúrbios, não pode haver adolescência, ou ela perde a sua utilidade e seu sentido. ${ }^{95}$
}

Essas transformações que constroem a identidade do jovem, próprias da adolescência, são descritas por Rousseau através de uma analogia em relação ao mar, que se inquieta demasiadamente, demonstrando os sinais da tempestade, assim como o adolescente, que também passa por inquietações nesse momento de transição, o que se mostra por meio das paixões que começam a surgir:

Como o mugido do mar precede de longe a tempestade, essa tempestuosa revolução é anunciada pelo murmúrio das paixões nascentes; uma fermentação muda anuncia a aproximação do perigo. Uma mudança no humor, arroubos freqüentes, uma contínua agitação de espírito tornam a criança quase indisciplinável. Torna-se surda à voz que a fazia dócil; é um leão em sua febre; desconhece seu guia, já não quer ser governada. ${ }^{96}$

Como vemos, ainda atualmente, as transformações da juventude fazem com que o jovem fique irreconhecível, questione os valores nos quais acreditava até então e desconsidere as

\footnotetext{
${ }^{94}$ Ibidem, p. 271.

${ }^{95}$ BECKER, p. 64.

${ }^{96}$ ROUSSEAU, Emílio, p. 272.
} 
opiniões de seus educadores, dando certa vazão às paixões. Becker afirma que devido a essas transformações, entre os adolescentes: "Há os que querem reproduzir a vida e os valores da família e da sociedade, há os que contestam, rejeitam e querem mudar; os que fogem, os que lutam, os que assistem, os que atuam... enfim, existem inúmeras escolhas". 97

Daí a importância de os educadores serem firmes e bem orientados quanto a seus princípios educativos, quanto a seus objetivos, posto que seu trabalho nesse período é primordial para que a educação realizada até então não se perca, como afirma Rousseau: “... os odres que mantinhas fechados estão abertos; os ventos já se libertaram; não abandones por mais nenhum instante o leme, ou tudo estará perdido". 98

De um modo geral, não abandonar o leme significa não deixar de tentar uma educação em que se eduque para que o adolescente seja capaz de reconhecer as paixões que lhe são prejudiciais e não se sujeitar a elas: "À medida que ele for adquirindo luzes, escolhei as idéias que com elas se relacionem; à medida que seus desejos se acenderem, escolhei quadros próprios a reprimi-los". 99

As paixões constituem a grande ameaça à educação, pois é através delas que, num primeiro momento, o amor de si se transforma em amor próprio ou orgulho, fazendo com que, a partir daí, o homem já não se veja como um igual entre os seus semelhantes, mas como alguém melhor que os outros, o que justifica um pensamento egocêntrico, que boicota a idéia de vontade geral, assim como de direitos, deveres e leis iguais para todos. Nesse momento, como afirma o autor: "Ele cede mais às inclinações dos outros do que às suas próprias, e o amor-próprio faz mais libertinos do que o amor". 100

Esse egocentrismo é mais um motivo para considerarmos a adolescência como o período mais crítico, no qual o tempo é curto em relação a tudo que se precisa ensinar, como os valores morais, o que, de certo modo, se dá por meio da educação negativa. Rousseau afirma que seria bom se fosse possível prolongar a juventude ou, pelo, menos, impedir ao máximo os jovens do contato com uma sociedade onde hajam maus costumes, isto é, degenerada:

O emprego da infância é pouca coisa. O mal que nela se introduz não é irremediável, e o bem que se faz nela pode vir mais tarde; mas o mesmo não ocorre com a primeira idade em que o homem

\footnotetext{
${ }^{97}$ BECKER, p. 13.

${ }^{98}$ ROUSSEAU, Emílio, p. 272.

${ }^{99}$ Idem, p. 303.

${ }^{100}$ Ibidem, p. 455.
} 
começa verdadeiramente a viver. Essa idade nunca dura o bastante para o uso que dela devemos fazer, e sua importância exige uma atenção contínua; eis porque insisto sobre a arte de prolongá-la. (...) De uma maneira geral observamos maior vigor de alma nos homens cujos anos de juventude foram preservados de uma corrupção prematura do que naqueles em que a desordem começou juntamente com o poder de entregar-se a ela, e esta é sem dúvida uma das razões por que os povos que têm bons costumes geralmente ultrapassam em bom senso e em coragem os povos que não os têm. ${ }^{101}$

É devido a essa concessão que faz às inclinações dos outros que os valores dos pais e educadores perdem seu valor, posto que ao conviver com outros jovens, que têm valores diferentes daqueles que vivenciou até então, os jovens começam a contestar a formação recebida, como se fosse algo desnecessário a sua educação, importando-se mais em agradar o grupo de amigos do que em manter-se educado, conservando a formação dada pelos educadores:

\footnotetext{
Outras maneiras de pensar produziram sozinhas essas diferenças. Seu coração ainda é o mesmo, mas suas opiniões mudaram. Mais lentos para se alterarem, seus sentimentos acabarão por se alterar através delas, e somente então ele estará realmente corrompido. Mal entrou no mundo já adquire uma segunda educação totalmente oposta à primeira, pela qual aprende a desprezar o que estimava e a estimar o que desprezava; fazem com que encare as lições de seus pais e professores como um jargão pedante, e os deveres que lhe pregaram como uma moral pueril que se deve desdenhar quando adulto. Ele se crê obrigado pela honra a mudar de comportamento; torna-se atrevido sem ter desejos e presumido por vergonha. Zomba dos bons costumes antes de ter tomado gosto pelos maus, e gaba-se de libertinagem sem saber ser libertino. ${ }^{102}$
}

Em outras palavras, considerando que a sociedade civil atual está corrompida, é preciso fazer com que o educando, mesmo em contato com ela, seja capaz de se manter imune aos seus vícios para que não se degenere, para que se preserve de acordo com os princípios educativos estabelecidos por Rousseau. ${ }^{103}$

É importante considerar que educar, nesse período de crise, é ir na contra-mão daquilo que o adolescente pensa ser o certo no momento, é uma tarefa bastante complicada. Segundo

\footnotetext{
${ }^{101}$ Ibidem, p. 303-4.

102 Ibidem, p. 454-5.

${ }^{103}$ Princípios que serão esmiuçados no capítulo seguinte.
} 
Becker, é preciso que os adultos que se relacionam com eles tenham segurança e sabedoria para decidir e atuar:

A capacidade de abertura e reflexão desses pais [e educadores], a maneira com que lidam com seus próprios conflitos, e a compreensão que tiverem com relação aos conflitos dos filhos é que vão determinar a sua reação perante o adolescente. O uso da violência, da repressão e do autoritarismo, e por outro lado, a falta total de limites e a satisfação de todos os desejos e caprichos podem criar sérias dificuldades ao desenvolvimento da personalidade do adolescente. No entanto, se houver uma atitude equilibrada e sobretudo compreensiva por parte dos pais, e também dos filhos, pode surgir entre eles um novo relacionamento, respeitoso e amigo. ${ }^{104}$

Desse modo, não se trata de isolar Emílio do contato com outras pessoas, com as paixões que podem degenerá-lo. Pelo contrário, como afirma Rousseau, "Emílio não é um selvagem para viver nas selvas", mas deve ter sua educação voltada para idéia de convivência mesmo numa sociedade degenerada. Assim, o autor afirma que:

Para viver no mundo, é preciso saber lidar com os homens, é preciso conhecer os instrumentos que permitem influir sobre eles; é preciso calcular a ação e a reação do interesse particular na sociedade civil e prever os acontecimentos com uma exatidão tal que raramente nos enganemos em nossos empreendimentos ou que, pelo menos, tenhamos usado dos melhores meios para sermos bemsucedidos. $^{105}$

Esse conhecimento acerca da vida em sociedade deve ocorrer na prática. Rousseau afirma que não basta fazer discursos aos adolescentes tentando preveni-los de certos males, mas que é preciso mostrar-lhes os prejuízos dos males que queremos evitar:

Não vos percais, pois, em belos raciocínios para provar ao adolescente que ele é um homem como os outros, sujeito às mesmas fraquezas. Fazei com que sinta isso, ou então nunca o saberá. Este é mais um caso de exceção às minhas próprias regras; é o caso de expor voluntariamente meu aluno a todos os acidentes que lhe possam provar que ele não é mais sábio do que nós. ${ }^{106}$

\footnotetext{
${ }^{104}$ BECKER, p. 39-40.

${ }^{105}$ ROUSSEAU, Emílio, p. 331.

${ }^{106}$ Idem, p. 325.
} 
Nesse contato com o mundo, contrapondo as idéias de Rousseau à atualidade, é preciso prever a influência que os jovens recebem dos meios de comunicação e fazer com que tenham consciência crítica para analisar essas informações. Becker afirma que "o mundo adulto manipula a juventude através dos poderosos meios de comunicação, criando ídolos e mitos, alienando-a, dirigindo-a para pensar e se comportar de acordo com seus próprios interesses". ${ }^{107}$

E, ainda, acredita que quanto maior a ausência de educadores - como a família - na formação dos adolescentes, mais suscetíveis eles ficam às influências do meio externo:

Quanto mais a autoridade familiar se torna abstrata e vazia, maior a tendência do adolescente a aceitar fácil e cegamente qualquer autoridade, desde que ela seja bastante forte (...) [e que] os veículos de comunicação, em especial a televisão, são talvez os melhores meios de manipular as pessoas, fazê-las pensar e agir de modo 'conveniente' ${ }^{108}$

Daí a necessidade de que pais e educadores tenham autoridade em relação aos jovens, sendo claros na transmissão de informações e valores, para que os educandos sintam-se seguros em relação às coisas que encontram pelo mundo, na convivência com outras pessoas, nos meios de comunicação.

Para fazer com que o jovem tenha consciência crítica e autonomia ao se deparar com a diversidade de coisas do mundo, inclusive aquelas transmitidas pela mídia, é preciso estimular seu bom senso e sua liberdade de escolha com responsabilidade. Ensinar o educando a escolher bem é uma tarefa bastante difícil, mas essencial, posto que a adolescência é o momento em que esse ato assume um papel definitivo, como aponta Becker:

É na adolescência que começamos a aprender a escolher livremente. É um aprendizado que nunca termina, talvez porque escolher é uma das tarefas mais difíceis da vida. Sempre que optamos por alguma coisa, estamos perdendo muitas outras. $\mathrm{O}$ adolescente, frente às suas primeiras e inúmeras escolhas, muitas vezes vê-se confuso, angustiado. Mas poder escolher é um privilégio. E deve ser exercido sempre que possível. As alternativas existem, em grande número e dos mais diversos tipos. E optar por uma delas não é necessariamente um passo definitivo; sempre se pode voltar atrás e recomeçar. O mais importante é participar das escolhas, participar ativamente da vida, tanto como indivíduo como parte integrante da sociedade. O adolescente não é o futuro da pátria, nem a

\footnotetext{
${ }^{107}$ BECKER, p. 59.

${ }^{108}$ Idem, p. 70.
} 
esperança do amanhã. Seu lugar é aqui, seu tempo é o presente, e sua vida lhe pertence para vivê-la da maneira que escolher.

Portanto, quando se afirma que o tempo do adolescente é o tempo presente, é preciso considerar que é necessário ter em mente que esse conceito é bastante relativo à cultura, nível social etc. Isto é, que esse conceito se constrói socialmente e, portanto, depende da influência especial do meio em que o jovem vive.

Desse modo, acreditamos ser possível, através da educação, auxiliar o jovem na vivência desse período de sua vida, visando ao seu bem-estar, à sua formação plena, para a moralidade e para a cidadania, como pretendia Rousseau. Nesse sentido, Corti e Souza afirmam que:

Em suma, podemos afirmar que a juventude é sobretudo uma construção social e não um processo natural. Sendo assim, é muito variável. Isto quer dizer que ela não consiste apenas numa fase do ciclo biológico, representada por uma idade cronológica (ter 15 ou 16 anos) e por certos estados fisiológicos como a maturidade do aparelho reprodutor, mas vai muito além disso. Ser jovem implica possuir determinadas características e exercer certos papéis sociais. Como as sociedades não são iguais umas às outras, os papéis sociais atribuídos aos jovens variam entre elas - e dentro delas. Por isso não se pode formular um conceito universal e homogêneo de juventude, pois como categoria social ela muda conforme a sociedade em questão. ${ }^{109}$

A importância dada à adolescência é um fenômeno relativamente novo, pois até o século XIX a infância era o momento em que a criança era tratada como um pequeno adulto e assim que tivesse as transformações físicas, era considerada apta para adentrar à vida adulta. Desse modo, não havia uma construção da personalidade do jovem para que ele refletisse sobre seus valores e suas crenças, tomando as decisões relativas à sua vida enquanto adulto. Como aponta Becker: “Até poucos anos, ser jovem era uma coisa a ser vivida apressadamente em direção ao ser adulto, como podem testemunhar nossos avós. A adolescência era uma pedra no caminho da entrada no sistema social". ${ }^{110}$

Nesse mesmo sentido, Corti e Souza acreditam que:

Mesmo concordando haver um caráter de transitoriedade na experiência juvenil, como em todas as outras fases da vida, fica claro que ela não se limita à expectativa de um tempo futuro. Afinal, os

\footnotetext{
${ }^{109}$ CORTI e SOUZA, p. 22.

${ }^{110}$ BECKER, p. 58.
} 
jovens participam ativamente da vida social, trabalhando, votando, vivendo sua sexualidade. Eles vivem o seu próprio tempo, desfrutando das vantagens e enfrentando as desvantagens de sua condição. Assim, negam-se a viver em função de um futuro incerto e buscam construir sentidos para a sua vida no presente. ${ }^{111}$

Para tentar elucidar características próprias dessa fase, foi realizada uma breve sondagem, organizada com o auxílio das questões apresentadas no livro Retratos da Juventude Brasileira, de Helena Abramo e Pedro Branco, acerca das impressões que os próprios jovens e alguns adultos têm em relação à adolescência e à vida em torno da política. Constatou-se, entre as 200 entrevistas realizadas, durante o ano de 2006, nas quais participaram, aproximadamente 150 jovens - de 15 a 21 anos - e 50 adultos - de 22 a 55 anos - que freqüentavam os três anos do Ensino Médio, tanto Regular como Educação de Jovens e Adultos, que, ao mesmo tempo em que há uma homogeneidade em determinados aspectos, há heterogeneidade em outros, o que comprova as idéias de Corti e Souza de que o fenômeno da adolescência depende não apenas de uma certa maturação biológica, mas de fatores culturais, sociais, econômicos etc.

Num primeiro momento, foi perguntado se os entrevistados consideravam a juventude como algo bom ou ruim e então, a grande maioria, isto é, $75 \%$, respondeu que achavam a juventude um período bom, apontando, entre os motivos mais citados, fatos como não ter muitas preocupações e responsabilidades, poder curtir a vida à vontade, ser livre, poder se divertir muito e ter disposição para fazer as coisas, como as características que garantem considerar a adolescência como uma fase boa da vida.

Quanto às características negativas da juventude, o fator mais apontado foi o de que as pessoas mais velhas não têm respeito pelos mais jovens, não acreditam ou não confiam nos adolescentes. Depois, o que pesa mais é o início das responsabilidades e, ao mesmo tempo, a impossibilidade de fazer o que quiser, além da dependência em relação aos pais, que também foi bastante citada, e da falta de oportunidade de emprego.

Perguntados sobre o problema que atualmente mais os preocupavam, entre as principais respostas estavam o desemprego, a violência, as drogas, o futuro e a política no Brasil. Os assuntos pelos quais têm mais interesse são aqueles relacionados ao crescimento que podem obter através dos estudos, as oportunidades e o crescimento em relação a emprego, questões referentes à política e a situação econômica do país, eventos, música e baladas e em relação à família.

\footnotetext{
${ }^{111}$ CORTI e SOUZA, p. 23.
} 
Os assuntos que mais discutem com os pais são acerca do futuro, da família e de questões financeiras. Com os amigos costumam falar sobre namoros, diversão, emprego e outros assuntos muito variados, praticamente sobre todas as coisas e, interessante, alguns apontam para a necessidade de falar com os amigos sobre coisas que não podem falar com os pais, mas sem especificá-las. $\mathrm{Na}$ escola apontaram essencialmente assuntos relacionados aos estudos, ao funcionamento da escola e à educação de um modo geral. Com a sociedade acham importante discutir, especialmente, temas relacionados à política, às leis e aos direitos e deveres do cidadão, depois apontam a educação como um tema importante e, ainda, outros temas variados, como o futuro, trabalho etc.

Quanto ao período que determina até quando se é jovem, a grande maioria afirmou que as pessoas deixam de ser jovens quando se tornam responsáveis pelos próprios atos, em seguida, quando faz vinte e um anos, depois alguns afirmaram que nunca se deixa de ser jovem, só se adquire mais responsabilidades ou ainda, quando quer ou se acha velho, pois é um estado de espírito.

A grande maioria, isto é, $76 \%$ das pessoas, acredita que os jovens podem mudar o mundo, muitos acrescentaram que, para isso, precisam ter o desejo e se empenhar. Em relação ao que mudariam, é interessante que se incomodam com a mesma questão tratada por Rousseau no Discurso, apontando a desigualdade social como a primeira coisa que deveria ser mudada ou eliminada no mundo. Depois apontam que são necessárias mudanças no campo da política, que as pessoas deveriam ter um pensamento mais solidário e que houvesse menos violência. Entre as principais mudanças que fariam, também gostariam de mudar coisas relativas à vida pessoal.

Como foi possível perceber, pelo menos nessa breve sondagem, os jovens têm algumas noções acerca de determinados temas relacionados à política e à cidadania, mas essas noções não parecem partir de uma formação para a vida pública, e sim de informações obtidas a partir da própria vivência, o que parece é que a formação para entender melhor essas questões não é bem organizada e que o que a família e a escola priorizam são os conteúdos básicos, como a aprendizagem em tornos dos conhecimentos da Matemática, da Língua Portuguesa, da Biologia, entre outros, esquecendo-se de que é necessário formar o jovem para vida social e política, oferecendo-lhe as informações necessárias para que conheça a estrutura e o funcionamento da sociedade, para que possa participar enquanto cidadão e propiciar determinadas transformações. 
Os valores mais apontados quando se referem a uma sociedade ideal, mais uma vez compartilhando com as idéias de Rousseau, ou melhor, como seus princípios para a educação proposta no Emílio, são essencialmente as virtudes, como respeito, solidariedade, bom senso, verdade, humanismo etc. Outro fator essencial, segundo eles, para que tenhamos uma boa vida social é uma educação de qualidade, isto é, uma boa formação para os jovens, e, ainda, apontam para a necessidade de que a organização política também tenha qualidade, por exemplo, no que diz respeito às leis, aos direitos e deveres do cidadão.

No que diz respeito à garantia de seus direitos, eles afirmam que podem tê-los garantidos através da política e do cumprimento das leis, se tiverem virtudes, ou seja, se estiverem com a razão, se forem conscientes desses direitos, o que pode ocorrer por meio da educação e se agirem para reivindicar seus direitos.

Das pessoas entrevistadas, $74,5 \%$ respondeu que a política é muito importante, e ainda, quanto à influência direta da política em suas vidas, $73,5 \%$ das pessoas entrevistadas responderam que influencia muito. Em contrapartida, 35,5\% respondeu que suas atitudes influenciam pouco na política, enquanto $30,5 \%$ respondeu que podem influenciar muito na política e $27 \%$ respondeu que não pode influenciar na política; $7 \%$ não respondeu com clareza e poucos apontaram a participação política como possibilidade de mudança, como por exemplo, a importância do voto.

Perguntados sobre a participação ou o interesse quanto a assuntos relacionados à política, $69,5 \%$ respondeu que só lê ou assiste noticiário sobre política de vez em quando; $66,5 \%$ só conversa sobre política às vezes; $64 \%$ afirmam que apenas esporadicamente conversa sobre os candidatos às eleições; 80,5\% dos entrevistados nunca assinaram quaisquer manifestos de protesto ou reivindicações; $93,5 \%$ nunca trabalhou nas eleições; $82 \%$ nunca participou de grupos com o objetivo de resolver problemas do bairro ou da cidade; $86,5 \%$ nunca participou de movimento ou causa social; $84,5 \%$ nunca participou de manifestações contra ou a favor do governo; $78,5 \%$ dos entrevistados nunca fez qualquer pedido aos políticos; $88 \%$ nunca participou de reuniões de partidos políticos; e $82 \%$ nunca participou de nenhuma atividade política.

Considerando os dados acima, embora as pessoas saibam da importância da política em suas vidas, ainda não se conscientizaram sobre a necessidade de participação em atividades políticas e nem sobre as atitudes políticas que definem o papel do cidadão. Então, se considerarmos que os jovens entrevistados freqüentam instituições sociais, como a escola, por 
exemplo, há pelo menos 11 anos, é possível perceber que não houve uma formação voltada diretamente para a cidadania. Ou seja, as instituições sociais como um todo não realiza essa função e a escola, em particular, objeto de nosso interesse, não conscientiza os jovens acerca da cidadania, o que, como já foi mencionado, fica apenas no plano teórico ou burocrático, isto é, nos documentos oficiais escolares, como planejamento anual e os próprios PCNs, entre outros.

No que diz respeito à forma de governo, $70 \%$ afirma que a melhor, em todos os casos, é a democracia. Em relação ao posicionamento político, 45,5\% afirmam não saber se posicionar politicamente, enquanto $39 \%$ não assumem posição alguma.

Aproximadamente $17,5 \%$ dos entrevistados afirmaram que a participação política da população nas decisões importantes do governo resolveria os problemas do Brasil, 9,5\% acredita que a atuação de um líder forte comprometido com mudanças significativas seria a melhor solução e $66 \%$ apontam para a idéia de que as duas alternativas, simultaneamente, possibilitariam soluções para os problemas brasileiros.

Ao perguntar o que entendem por cidadania, $15 \%$ respondeu que se trata de ter direitos e deveres, $14,5 \%$ afirmou que é quando existe ajuda entre os cidadãos, 12,5\% acredita que é quando as pessoas têm virtudes como solidariedade, caridade, respeito etc, $9 \%$ apontam para a idéia de que cidadania significa igualdade (social, econômica etc) entre as pessoas e, é interessante apontar uma afirmação, na qual o entrevistado concorda que é "fazer com que as leis e os direitos prevaleçam e ter o direito de escolha desde que não prejudique o outro", conceituação que se aproxima daquela defendida por Rousseau, em que só as leis podem garantir a cidadania e é preciso pensar coletivamente.

Em primeiro lugar, 35\% apontam a liberdade ou a possibilidade de fazer escolhas como o direito mais importante para o cidadão, $17,5 \%$ acreditam que o direito de ser respeitado é o mais importante e $17 \%$ afirmam que o mais importante é ter direito à educação. Em seguida aparecem a igualdade e a saúde como direitos relevantes para a vida do cidadão.

Para os entrevistados, o direito que consideram mais importante de ser criado para os jovens, é a garantia de emprego, tendo $18,5 \%$ dos votos. Depois, acham importante que os jovens tenham acesso a uma educação gratuita e de qualidade, inclusive com cursos técnicos e ensino superior, com 11,5\% dos votos. Em seguida, alguns apontaram para a necessidade de que os jovens possam ser responsabilizados pelos seus atos, reduzindo a maioridade; outros acreditam 
que os jovens deveriam ter direito a um país melhor, ao poder de participar das decisões, de serem mais ouvidos ou terem suas opiniões mais respeitadas.

Considerando os dados acima, constatamos que muitas pessoas, embora apontem para a idéia de que a participação política da população e a atuação forte de um líder sejam fundamentais para resolução dos problemas do Brasil, não participam e nem buscam informações sobre como a política funciona enquanto estrutura e funcionamento social do país, como pudemos notar quando $80,5 \%$ dos entrevistados afirmam que nunca assinaram quaisquer manifestos de protesto ou reivindicações, 93,5\% nunca trabalhou nas eleições, $82 \%$ nunca participou de grupos com o objetivo de resolver problemas do bairro ou da cidade, $86,5 \%$ nunca participou de movimento ou causa social, $84,5 \%$ nunca participou de manifestações contra ou a favor do governo, 78,5\% nunca fez qualquer pedido aos políticos, $88 \%$ nunca participou de reuniões de partidos políticos e, enfim, $82 \%$ nunca participou de nenhuma atividade política.

Em outras palavras, mesmo afirmando que a participação política da população é fundamental no funcionamento político adequado para o país, a grande maioria não participa, ou seja, têm a informação acerca da importância de um cidadão participativo, mas não a consciência ou o conhecimento em torno dessa prática, de onde se vê a necessidade de realizar um trabalho direcionado para a conscientização dos educandos, informando-os sobre questões políticas e estimulando-os a se considerar cidadãos, tendo claro em mente o que é cidadania.

Embora os jovens não demonstrem envolvimento prático com ações voltadas à política, é preciso considerar o apontamento que fazem em relação à importância da política em nossas vidas, valorizando a adolescência como um período potencialmente positivo em relação à cidadania, posto que os jovens podem ser esclarecidos e formados politicamente. Daí o intuito de apontar (no capítulo seguinte), através dos princípios educativos desenvolvidos por Rousseau no Emílio, uma formação voltada para a vida pública, isto é, para a cidadania.

É importante considerar que para Rousseau, cada fase da vida humana deve ser valorizada em si mesma, pois todas constituem e possibilitam a formação plena do educando. Ele defende a idéia de que o adolescente tenha uma infância sadia, desenvolvendo-se bem fisicamente e que, depois de estar bem desenvolvido quanto à formação do corpo, do físico, ao chegar próximo dos 12 anos, seja considerado como um ser moral, já que é nesse momento que "nasce" para se relacionar com os outros, conviver socialmente. 
Isto é, na adolescência é preciso desenvolver o processo educativo tendo em mente que já se trata de um ser moral, que é capaz de analisar suas relações com os outros e com as coisas ao seu redor, começando a fazer suas próprias escolhas, o que pressupõe uma formação voltada para a autonomia, conceito de extrema relevância para a formação política:

Em vez de deixá-lo estragar-se no ar corrompido de um quarto, que seja levado diariamente até um prado. Ali, que corra, se divirta, caia cem vezes por dia, tanto melhor, aprenderá mais cedo a se levantar. O bem-estar da liberdade compensa muitos machucados. Meu aluno muitas vezes terá contusões; em compensação, estará alegre. Se vossos filhos se machucam menos, estão sempre contrariados, sempre presos, sempre tristes. Duvido que a vantagem esteja de seu lado. (...) Portanto, é importante começar a considerá-lo agora como um ser moral. ${ }^{12}$

Mas não se trata de priorizar as transformações físicas, e sim aquelas que influenciam mais diretamente nas atitudes e no jeito de pensar. A partir da adolescência, com a capacidade de abstração e certa autonomia, como afirma Becker, o jovem adquire:

A capacidade de engendrar possibilidades, formular hipóteses e pensar a respeito de símbolos sem base na realidade, [o que] permite ao adolescente passar a especular, abstrair, analisar, criticar. Essa transformação na inteligência afeta todos os aspectos da sua vida, pois ele utiliza as novas capacidades para pensar a respeito de si mesmo e do mundo que o cerca. ${ }^{113}$

Fazer as próprias escolhas é algo determinante na vida do jovem, principalmente porque, ao encontrar um mundo de valores já constituído, pode aceitá-lo ou querer transformações. Assim, Corti e Souza afirmam que:

Se considerarmos a sociedade como uma contínua construção que requer instituições e regras sociais mais ou menos estáveis, podemos dizer que o jovem chega depois a este mundo. Isto significa que boa parte do que lhe é apresentado foi construído pelos outros, que insistem em convencê-lo de que este é o "melhor dos mundos". No entanto, por não ter participado e se envolvido em sua construção, o jovem possui mais condições de estranhá-lo e questioná-lo. Isso não significa que ele seja um revolucionário ou que se comporte como um viajante num mundo

\footnotetext{
${ }^{112}$ ROUSSEAU, Emílio, p. 67.
}

${ }^{113}$ BECKER, p. 26. 
desconhecido. Mas faz parte de sua condição social estar mais desapegado e aberto a novas experiências do que os adultos. ${ }^{114}$

Mas quais podem ser as reações do jovem ao se deparar com essa sociedade já estruturada e, de certa forma, com os valores dados? Segundo Corti e Souza existem duas maneiras principais de o jovem reagir frente ao mundo. São elas:

- Integração à sociedade: os jovens apresentam maior facilidade para se adaptar às mudanças frenéticas da sociedade moderna (uso das novas tecnologias, adesão às novas profissões) e capacidade de propô-las, seja no campo cultural, social ou político.

- $\quad$ Ruptura com a sociedade: maior tendência para questionar a ordem social, seja através dos movimentos juvenis de contestação, seja através de condutas transgressoras e desviantes. ${ }^{115}$

Considerando que é a partir da adolescência que o jovem começa a pensar por si mesmo e a fazer suas próprias escolhas, podendo ter uma atitude construtiva ou destrutiva em relação ao mundo, é esse o momento em que o processo educativo é mais trabalhoso e quando o educador precisa ter mais empenho, como afirma Rousseau é o momento em que "os odres que mantinhas fechados estão abertos; os ventos já se libertaram; não abandones por mais nenhum instante o leme, ou tudo estará perdido". ${ }^{116}$. Até a infância, a criança, na grande maioria das vezes, age por imitação dos atos de seus educadores - pai, mãe, professores etc -, seguindo os mesmos valores transmitidos por eles. Mas a partir da adolescência, os pais e professores deixam de ser um referencial tão forte, dando lugar, principalmente, ao grupo de colegas.

Assim, fica muito mais difícil transmitir conhecimentos e valores, fica muito mais complicado fazer com que o jovem permaneça direcionando suas atitudes para os valores morais transmitidos pela família, preservando-se das paixões e da degeneração da sociedade corrompida, pois se comparam muito entre si, e por meio dessas comparações, sentem-se os donos da verdade e, comumente, o centro do universo, menosprezando pais e educadores, como vemos na realidade atual.

Nesse momento, é indispensável contar com o apoio e a orientação dos educadores, pois mesmo que, por meio de uma atitude de rebeldia, pareça que o jovem despreze os valores da

\footnotetext{
${ }^{114}$ CORTI e SOUZA, p. 24.

${ }^{115}$ Idem, p. 24.

${ }^{116}$ ROUSSEAU, Emílio, p. 272.
} 
família e da escola, estas não podem abandoná-lo à mercê da própria sorte. Pelo contrário, nesse período de transformações é quando os adolescentes mais precisam da orientação e do apoio dos pais e educadores, para sentirem-se seguros na construção de sua autonomia e independência.

A qualidade dessa construção da autonomia é de extrema relevância para a formação do cidadão adulto que esse jovem será, pois determina sua participação ou submissão nos assuntos relacionados à sociedade, que, por sua vez, se determinará pela maneira como construiu sua independência. Corti e Souza acreditam que:

[A autonomia] faz parte da expansão do jovem em relação ao mundo social, à sua crescente capacidade de analisar situações, hierarquizar problemas, fazer julgamentos e realizar escolhas. Trata-se de um processo de emancipação. Nesse sentido, os jovens costumam questionar, às vezes arduamente, as situações em que as decisões já estão prontas e acabadas, pois querem participar ativamente daquilo que lhes diz respeito. Reivindicam o direito de serem ouvidos e considerados. Passam a rejeitar cada vez mais a tutela dos adultos. Assim, podemos dizer que a autonomia está relacionada à autodeterminação, liberdade, independência e capacidade de governar-se a si mesmo. ${ }^{117}$

Becker acredita que, nesse período o adolescente:

Discorda das idéias dos pais, e isso lhe traz remorso e culpa; oscila entre o desejo de independência e autonomia, e a necessidade de "colo" e proteção, e isso o confunde e angustia. Ele precisaria dos pais tanto para contestá-los, quanto para sentir-se seguro enquanto conquista sua independência. ${ }^{118}$

Becker afirma que na adolescência o jovem mudará por completo, não apenas no que diz respeito às transformações físicas, mas especialmente em relação ao seu jeito de ser, como numa metamorfose: "Se a lagarta pensa e sente, também o seu pensamento e sentimento se transformarão. Serão agora o pensar e o sentir de uma borboleta. Ela vai ter um outro corpo, outro astral, outro tipo de relação com o mundo". ${ }^{119}$

É por isso que se trata de um momento especial no processo educativo, que merece um olhar mais direcionado e um trabalho mais árduo, com ênfase no respeito mútuo, na afetividade familiar, entre professor e aluno, na consciência e responsabilidade pelos próprios atos, nos

\footnotetext{
${ }^{117}$ Ibidem, p. 26.

${ }^{118}$ Ibidem, p. 38.

${ }^{119}$ BECKER, p. 14.
} 
princípios de necessidade e utilidade, entre outras coisas. Esses preceitos servem para orientar o trabalho dos educadores, fortalecendo sua prática nesse momento tão delicado da formação do homem e do cidadão. Tratando da infância, Rousseau afirma que a adolescência é o momento mais terrível do processo educativo: "O mais violento, o mais terrível ainda não se revelou". ${ }^{120}$

De um modo geral, é preciso considerar a crise da adolescência não apenas como um período de rebeldia contra os pais ou como uma tensão em relação à sexualidade, por exemplo, mas como um período que contribui para a construção do adulto, pois possibilita a oportunidade de, por meio da convivência com outras realidades, como por exemplo, o próprio aprendizado que se adquire na vida social, observar, analisar e entender as coisas que os cercam, como o próprio funcionamento da sociedade, para então, selecionar as informações e valores nos quais acredita, sem que absorva os mesmos de forma submissa e acrítica. Como afirma Becker:

\begin{abstract}
...essa "crise adolescente" pode não ser apenas o fruto de conflitos familiares e sexuais, ou de busca de identidade, como querem nos convencer. Talvez ela seja, no mínimo, também, a expressão da revolta perante uma herança imposta, uma tentativa de transformar um mundo que ele não pode aceitar. É importante que se reconheça nos conflitos e no comportamento do adolescente o confronto cultural e ideológico com uma civilização em crise. E a sua importância como uma força geradora de transformação, uma força criativa fundamental não só para o crescimento do adolescente, mas de uma sociedade como um todo. ${ }^{121}$
\end{abstract}

Nessa construção de sua própria visão acerca do mundo, a escola tem um papel determinante na vida do jovem, segundo Corti e Souza, principalmente:

Ao propor um diálogo com as informações e o conhecimento sistematizado sobre a juventude e diferentes questões que a afetam, [para] poder contribuir para que os educadores consigam estabelecer, de fato, um diálogo com seus alunos e alunas jovens e, assim, fazer da escola um espaço público democrático. ${ }^{122}$

Para concluir, como afirma Rousseau, é preciso cuidar bem da educação dos adolescentes por se tratar de um momento decisivo na formação do homem e do cidadão: "Estás na idade

\footnotetext{
${ }^{120}$ ROUSSEAU, Emílio, p. 201.

${ }^{121}$ Idem, p. 72.

${ }^{122}$ CORTI e SOUZA, p. 06.
} 
crítica em que o espírito abre-se à certeza, em que o coração recebe sua forma e seu caráter e se fixa para toda a vida, quer para o bem, quer para o mal". ${ }^{123}$

E, ainda, é através da educação que se pode formar para a cidadania, como se pretende com os adolescentes:

É a educação que deve dar às almas a conformação nacional e de tal modo orientar suas opiniões e gostos, que se tornem patriotas por inclinação, paixão e necessidade. Uma criança, ao abrir os olhos, deve ver a pátria e até a morte não deverá senão vê-la. Todo o verdadeiro republicano sugou com o leite materno o amor à pátria, isto é, às leis e à liberdade. ${ }^{124}$

${ }^{123}$ ROUSSEAU, Emílio, p. 424.

${ }^{124}$ ROUSSEAU, Considerações, p. 277. 


\section{- I V -}

\section{A FORMAÇÃO DO JOVEM PARA VIDA PÚBLICA}

Neste capítulo serão comentados os princípios educativos desenvolvidos por Rousseau no decorrer do Emílio, que podem ser entendidos como uma espécie de parâmetro para a formação do jovem para a cidadania, o que se dá, por um lado, por meio do desenvolvimento da educação negativa, isto é, impedindo que o adolescente se deixe influenciar pelos vícios da sociedade degenerada, como o amor próprio e o orgulho e, por outro, priorizando o desenvolvimento de virtudes que formem o indivíduo para a moralidade, o que, por sua vez, aponta para a convivência com os outros, e assim, para a vida pública.

Em outras palavras, para Rousseau, o jovem só pode ser considerado um ser moral a partir do momento em que se relaciona com as outras pessoas, isto é, a partir do momento em que suas relações se baseiam em julgamentos ou princípios morais, o que, por sua vez, só é possível através da convivência social, da vida pública. Daí, a educação que pressupõe uma convivência com os outros - moralidade - é uma formação para a vida pública:

\footnotetext{
Enquanto sua sensibilidade permanece limitada a seu indivíduo, não há nada de moral em suas ações. Somente quando ele [o educando] começa a se estender para além dele, é que ele adquire primeiro os sentimentos, depois as noções de bem e mal, que o constituem verdadeiramente como homem e parte integrante de sua espécie. ${ }^{125}$
}

Embora tenhamos visto que Rousseau, implicitamente, aborda a educação do homem atitudes em relação a si próprio - e do cidadão - atitudes em relação aos outros -, no decorrer do Emílio, é a partir do livro IV que trata diretamente da adolescência, isto é, dos princípios necessários à formação do jovem em sua convivência social: "Nascemos, por assim dizer, duas vezes: uma para existir, outra para viver; uma para a espécie, outra para o sexo". ${ }^{126}$ Ou seja, é propriamente a partir da adolescência, momento no qual o jovem "desperta" para a moralidade, isto é, para pensar-se em relação aos outros e ter consciência da vida em coletividade, é que

\footnotetext{
${ }^{125}$ ROUSSEAU, Emílio, p. 284.

${ }^{126}$ Idem, p. 271.
} 
Rousseau se preocupa com a educação que possa tornar Emílio capaz de conviver bem em sociedade.

Para desenvolver essas virtudes necessárias a boa convivência social, Rousseau aponta várias situações e preceitos que nortearão o educando por toda sua vida pública, tais ensinamentos não são apontados apenas na adolescência. Ou seja, há princípios educativos que, embora apontados em outros livros do Emílio, trazem idéias que contribuem para a formação do cidadão, para a convivência com os outros, como podemos notar quando Rousseau afirma que na infância, mesmo se tratando de um período no qual a criança vai ter boas atitudes por imitação, posto que não pode raciocinar por si mesma sobre como agir bem, é melhor que o faça por imitação do que deixe de aprender o preceito de fazer o bem:

Sei que todas essas virtudes por imitação são virtudes de macaco, e nenhuma boa ação é moralmente boa a não ser quando a fazemos como tal, e não porque outros a fazem. Numa idade, porém, em que o coração ainda nada sente, devemos fazer com que as crianças imitem os atos cujo hábito lhes queremos dar, enquanto elas não o possam fazer por discernimento e por amor ao bem. $^{127}$

De um modo geral, esses princípios serão estabelecidos segundo o critério de seguir a marcha da natureza e, também, de combater as paixões, lembrando que não se trata aqui das paixões naturais - o amor de si e a piedade natural - que são positivas por terem sido dadas pela natureza, mas de enfatizar a educação negativa. Isto é, o trabalho do educador na juventude do educando é fazer com que o jovem não se deixe levar pelas paixões:

É verdade que, não podendo viver sempre sozinhos, dificilmente serão sempre boas [as paixões, como as naturais]; essa dificuldade até mesmo aumentará necessariamente com suas relações, e é nisso sobretudo que os perigos da sociedade nos tornam a arte e os trabalhos mais indispensáveis para prevenir no coração humano a depravação que nasce de suas novas necessidades. ${ }^{128}$

Educar seguindo o princípio da educação negativa é essencial para que o jovem adquira virtudes, impedindo que prevaleçam as paixões, característica fundamental para viver bem em

${ }^{127}$ Ibidem, p. 108.

${ }^{128}$ Ibidem, p. 275. 
sociedade: "Nunca repetirei demais que a boa educação deve ser negativa. Impedi os vícios de nascer e tereis feito muito pela virtude". ${ }^{129}$

Para saber lidar com as paixões, Rousseau estabelece dois passos: "Eis, portanto, o sumário de toda a sabedoria humana quanto ao uso das paixões: 1. sentir as verdadeiras relações do homem, tanto na espécie quanto no indivíduo; 2. ordenar todas as afecções da alma conforme essas relações". 130

Rousseau valoriza o conhecimento de si tanto quanto o conhecimento acerca dos outros, isto é, é necessário que Emílio se conheça, para que possa controlar seus impulsos em relação aos vícios e, ao mesmo tempo, é preciso que conheça as pessoas com as quais convive, para que possa detectar se essa convivência lhe trará malefícios ou benefícios ou, em outras palavras, para saber se o ajudarão ou não a continuar no caminho da natureza. Mais uma vez, vemos o autor valorizar a idéia de que é preciso seguir a marcha da natureza, estimulando o uso do bom senso, como na atenção dada apenas às necessidades, e desprezando as paixões artificiais, através da educação negativa.

É interessante notar que, ao se fazer uma leitura do Emílio buscando apontar os princípios educativos, não perdemos de vista o pressuposto de que se trata de uma obra hipotética e, ainda, o de que Rousseau não descreve como deveria ocorrer a educação formal, na escola. O autor estabeleceu, através de sua hipótese, idéias norteadoras para que a formação do homem e do cidadão obtivesse eficácia, isto é, apontou princípios educativos que considerava essenciais para essa formação plena, para moralidade e para a cidadania.

É pautando-se nesse pressuposto que os princípios educativos serão tomados ao longo desse capítulo, isto é, não considerando o Emílio como se fosse uma manual acerca da educação ou uma receita que pudesse ser aplicada nos dias de hoje, assim como não era objetivo de Rousseau quando o escreveu, mas com o intuito de analisar algumas idéias que, ainda hoje, podem ser importantes para levar os educadores a refletirem sobre seus princípios educativos, relacionando-os com os rousseaunianos, para que estes iluminem a prática pedagógica e seja possível direcionar a formação dos educandos para a cidadania. Ou seja, trata-se de refletir sobre as idéias apresentadas na obra para clarificar a concepção de educação e as atitudes profissionais de educadores que almejam a formação de cidadãos.

\footnotetext{
${ }^{129}$ ROUSSEAU, Considerações, p. 279.

${ }^{130}$ ROUSSEAU, Emílio, p. 284.
} 
Os princípios educativos apresentados no decorrer do Emílio são essenciais para que os educadores possam refletir acerca de questões voltadas para a formação política dos educandos, pois através deles é que podemos conhecer o processo educativo que Rousseau considera capaz de desenvolver a formação do homem e do cidadão. É importante lembrar que, implicitamente, fica evidente que ambas se dão simultaneamente.

É preciso enfatizar que os princípios educativos para a cidadania estão presentes não apenas no livro IV - a partir da adolescência, da convivência com os outros -, mas, como se trata da formação do educando enquanto um processo que se dá no decorrer da vida, as idéias apresentadas desde o início do processo educativo e, portanto, da obra, se vinculam a esse objetivo: "Repito, a educação do homem começa com o nascimento; antes de falar, antes de ouvir, ele já se instrui”. ${ }^{131}$ Ou seja, a educação recebida desde os primeiros anos de vida influencia na formação do educando por toda vida, daí a necessidade de se apontar alguns princípios presentes em outros livros do Emílio.

Logo no início do Emílio, Rousseau destaca uma característica essencial para a cidadania: "O essencial é ser bom com as pessoas com quem se vive. Fora, o espartano era ambicioso, avaro, iníquo, mas o desinteresse, a eqüidade e a concórdia reinavam em sua cidade". ${ }^{132}$ Nesse primeiro momento, há ênfase no respeito mútuo, isto é, Rousseau afirma ser essencial que cada membro da sociedade seja desinteressado - priorizando a vontade geral -, trate igualmente seus concidadãos e que, no ambiente comum, que é a cidade, haja paz e boa convivência. Atualmente, vivemos um período de individualismo, em que cada um pensa e age em benefício próprio, independentemente da condição ou situação do outro, desse modo, é evidente que, ao ter em mente o princípio de respeito mútuo, o educador estimularia uma convivência mais respeitosa e, automaticamente, o respeito ao cumprimento do ideal de direitos iguais.

Rousseau defende também a idéia de que não se deve fazer o mal aos outros, o que, de certa forma, complementa o princípio de respeito às pessoas. Essa regra, atualmente, frente à competitividade imposta pelo capitalismo e ao individualismo, que são cada vez mais comuns, é extremamente importante de ser enfatizada e estimulada, para que os educandos cresçam conscientes da necessidade de se conviver bem em sociedade, respeitando todos ao seu redor. E aponta a necessidade de se conhecer esse princípio desde a infância: "A única lição de moral que

\footnotetext{
${ }^{131}$ Idem, p. 45.

${ }^{132}$ Ibidem, p. 11.
} 
convém à infância, e a mais importante em todas as idades, é a de nunca fazer mal a alguém. O próprio preceito de fazer o bem, se não estiver subordinado a este, é perigoso, falso e contraditório". 133

E, ainda, reforça esse preceito quando trata da educação do adolescente: "Sempre somos bem-sucedidos quando só queremos fazer o bem". ${ }^{134}$ Rousseau acrescenta que fazer o bem é algo próprio da missão humana: "Sabemos que a mesma missão é dada a todos e que quem ama o bem de todo o coração e o faz da melhor maneira que pode cumpre-a bem". ${ }^{135}$

Deve haver, inclusive, muito respeito e compromisso com o "fazer bem a educação" entre o educador e o educando, é preciso que o vínculo afetivo entre eles seja forte o suficiente para que se sintam "sócios" de um mesmo empreendimento, no caso, a educação:

... que jamais nos tirem um do outro a não ser por nosso consentimento. Essa cláusula é essencial, e eu até gostaria que o aluno e o preceptor se considerassem de tal modo inseparáveis que o destino de seus dias sempre fosse entre eles um objeto comum. Assim que vislumbrarem a separação no afastamento, assim que previrem o momento que deverá torna-los estranhos um ao outro, já o serão. (...) Quando, porém, consideram-se um ao outro como pessoas que devem passar os dias juntos, é importante para eles que se façam amar um pelo outro, e por isso mesmo se tornam queridos. $^{136}$

Embora a descrição realizada por Rousseau pareça exagerada, é interessante notar que o princípio que deve nortear a relação entre educador e educando é o de uma relação que pressupõe a preocupação com um projeto em comum, que, com certeza, é o sucesso do processo educativo. Essa relação é considerada, por Francisco, como contratual:

Assim como a instituição da sociedade e da própria família seriam para ele [Rousseau] baseadas no contrato firmado entre as respectivas partes que formam essas instituições, também a relação pedagógica seria baseada num contrato, o contrato pedagógico, firmado entre duas pontas dessa relação, professor e aluno, ou de modo mais geral educador/educando (que incluiria, além do par professor/aluno, o par pai/filho). ${ }^{137}$

\footnotetext{
${ }^{133}$ Ibidem, p. 109.

134 Ibidem, 351.

${ }^{135}$ Ibidem, p. 661.

${ }^{136}$ Ibidem, p. 31.

${ }^{137}$ FRANCISCO, Autoridade e contrato pedagógico, p. 103.
} 
Essa relação contratual entre educador e educando deve funcionar para garantir às partes direitos e deveres, de modo que o processo educativo se efetive com qualidade:

\begin{abstract}
As regras dessa relação devem ser vistas como objeto de um contrato, isto é, do mútuo e livre acordo entre as partes envolvidas. Somente assim essas partes poderão ter obrigações e vantagens, ou deveres e direitos, consciente e livremente acordados, sabendo de antemão o que podem ou não podem esperar do outro, o que podem ou não podem fazer com o outro. Somente assim se pode formular papéis claramente definidos para cada uma das partes, de modo que se possa ter em vista alcançar tanto a justa medida da autoridade do educador - sem abusos nem tampouco hesitações no exercício da autoridade -, quanto a justa medida na liberdade da criança - igualmente sem abusos dessa liberdade. ${ }^{138}$
\end{abstract}

Para que a relação educativa seja proveitosa é necessário que educando e educador criem um vínculo afetivo, se gostem, se respeitem e se preocupem mutuamente. Esse vínculo afetivo, como é evidente na realidade, é o que possibilita um "adentramento" do professor no mundo do aluno, especialmente do adolescente, mostrando-lhe que há uma verdadeira preocupação com o seu crescimento pessoal e intelectual para que a prática pedagógica se efetive. Por outro lado, quando o aluno não se sente respeitado, compreendido e até mesmo amado, há uma espécie de negação ao professor, o que impede a aproximação, levando normalmente à indisciplina e, conseqüentemente, prejudicando o processo educativo.

Da mesma forma, quando há omissão da responsabilidade em torno do processo educativo por parte do professor, é praticamente impossível contar com o sucesso da formação do educando. Corti e Souza apontam para importância da participação contínua e direta dos adultos, como os professores, na educação dos jovens:

Esta omissão do mundo adulto diante dos comportamentos juvenis na escola tem gerado efeitos bastante negativos para o conjunto do processo educativo dos jovens. Muitas condutas agressivas, intolerantes e preconceituosas dos estudantes têm se produzido livremente debaixo dos olhos dos professores. É preciso reconhecer que a construção da autonomia é um processo complexo, protagonizado pelo jovem, mas mediado pelas relações estabelecidas com o mundo adulto. Daí a importância do diálogo e da troca de experiências intergeracionais entre professores e alunos, pois

\footnotetext{
${ }^{138}$ Idem, p. 104.
} 
os primeiros têm papel importante na problematização de algumas referências trazidas pelos jovens e na ampliação de seus horizontes. ${ }^{139}$

Rousseau afirma ainda, a respeito do papel do educador, que deve ter bom senso em suas atitudes com os alunos - o que poderia ajudar as reflexões dos professores em relação aos seus métodos pedagógicos -, cuidando para não se limitarem a discursos vagos e pedantes quando pretenderem transmitir alguma informação ao educando:

\begin{abstract}
Não gosto de explicações em forma de discurso. Os jovens prestam pouca atenção nelas e não as retêm. As coisas! As coisas! Nunca terei repetido suficientemente que damos poder demais às palavras. Com nossa educação tagarela, só criamos tagarelas. (...) Suponhamos que, enquanto estudo com meu aluno o curso do sol e a maneira de se orientar, de repente ele me interrompe para me perguntar para que serve tudo aquilo. Que belo discurso irei fazer-lhe! (...) Quando tiver dito tudo, terei feito uma exibição de verdadeiro pedante, da qual não haverá compreendido uma única idéia. Ele teria como antes vontade de me perguntar para que serve orientar-se, mas não ousa, temendo aborrecer-me. Prefere fingir que entendeu o que o forçaram a escutar. Assim se fazem as belas educações. ${ }^{140}$
\end{abstract}

É interessante notar que, mesmo se tratando de uma educação hipotética e não real nem escolar, Rousseau apresenta exatamente o que vemos nos métodos mais utilizados nas escolas atuais, baseados em aulas expositivas, com a transmissão de conteúdos como se fossem verdades absolutas e sem a preocupação de explicitar aos alunos o objetivo de se ensinar determinadas coisas.

Por outro lado, o autor enfatiza a necessidade de se recorrer às experiências práticas para se transmitir os conteúdos, de deixar o aluno pensar por si mesmo, de deixar de lado os discursos, o excesso de aulas expositivas, centradas na figura do professor. Para ele o bom aluno seria aquele aluno pensativo, que buscasse o porquê das coisas, a razão de se ensinar determinados assuntos, o que, como vemos nas escolas, muitas vezes, é visto como um enfrentamento do aluno em relação ao professor; mesmo que este coloque em seu planejamento que quer formar o aluno crítico e questionador.

Enfim, muitos princípios apontados por Rousseau no decorrer do Emílio, fazem com que possamos refletir sobre a postura que temos enquanto educador, questionando nossos próprios

\footnotetext{
${ }^{139}$ CORTI e SOUZA, p. 132.

${ }^{140}$ ROUSSEAU, Emílio, p. 225.
} 
valores e, assim, redirecionando nossa prática de acordo com aquilo que almejamos e acreditamos, de uma forma independente e autônoma.

Aliás, autonomia é um dos princípios defendidos por Rousseau. Ele considera a idéia de dependência das coisas, isto é, de que temos a necessidade natural em relação a certos objetos, certas coisas, como algo próprio de nossa natureza. Nessa relação não há moralidade, portanto não pode resultar em ausência de liberdade ou vícios. Por outro lado, aponta para a dependência destes e para a necessidade de se cuidar da relação que o educando tem com as pessoas. Pois por haver moralidade, há o risco de se gerarem vícios morais: "Conservai a criança unicamente na dependência das coisas e tereis seguido a ordem da natureza no progresso de sua educação". ${ }^{141}$ Cita, ainda, como exemplo, os criados que na concepção rousseauísta também são educadores e podem prejudicar o processo educativo:

\footnotetext{
Afastai delas com o maior cuidado os criados que as provocam, irritam e impacientam, pois são cem vezes mais perigosos para elas do que os danos do ar e das estações. Enquanto as crianças só encontrarem resistência nas coisas e não nas vontades, não se tornarão nem irritadas, nem coléricas, e permanecerão mais facilmente saudáveis. ${ }^{142}$
}

Com isso, Rousseau deixa claro que é preciso que o educador tenha clareza acerca dos princípios que norteiam sua prática, além de ter o bom senso para tomar as decisões corretas com base nesses princípios. Por exemplo, é preciso ter clareza ao permitir ou proibir algo para a criança ou para o jovem, para que não tenham a impressão de que as decisões do educador são inseguras ou incertas, que podem ser negociadas ao seu bel prazer:

É importante acostuma-la desde cedo a não mandar nem nos homens, pois não é senhora deles, nem nas coisas, pois elas não a entendem. Assim, quando uma criança deseja algo que não está vendo e que queremos lhe dar, é preferível levá-la ao objeto a trazer o objeto até ela; dessa prática ela tira uma conclusão própria à sua idade, que não há outro meio de lhe sugerir. ${ }^{143}$

O homem sábio sabe permanecer em seu lugar, mas a criança que não sabe o seu não será capaz de permanecer nele. Junto a nós, existem mil lugares por onde a criança pode sair de seu lugar; cabe aos que a educam mantê-la nele, e esta não é uma tarefa fácil. Ela não deve ser nem um animal,

\footnotetext{
${ }^{141}$ Idem, p. 78.

142 Ibidem, p. 52.

${ }^{143}$ Ibidem, p. 53.
} 
nem um homem, e sim criança. É preciso que ela sinta a sua fraqueza e não que a sofra; é preciso que ela dependa, e não que obedeça; é preciso que ela peça, e não que mande. A criança só está submetida aos outros em razão de suas necessidades, e porque vêem melhor do que ela o que lhe é útil, o que pode contribuir ou prejudicar a sua conservação. Ninguém tem o direito, nem mesmo o pai, de ordenar à criança o que não lhe serve para nada. ${ }^{144}$

Rousseau enfatiza a idéia de que a criança seja estimulada a pensar sobre as coisas especialmente as da natureza ${ }^{145}$ - que queremos que ela aprenda, que possa entrar em contato com essas coisas através da experiência prática e não dos livros ou de nossos discursos - que considera vazios e insignificantes para os pequenos. Com isso, notamos uma semelhança com os ideais construtivistas, representados especialmente por Piaget, Vygotsky e Emília Ferrero, que pressupõem a aprendizagem como um processo a ser construído pela criança, tendo o educador um papel diretivo, na qual ela possa pensar autonomamente e refletir sobre os objetos de estudo, relacionando suas observações com as experiências adquiridas no decorrer da vida. Daí a importância do educador, que pode nortear essa aprendizagem por ter mais conhecimentos: "Já que vivem juntos, como mais velho o senhor [preceptor, educador] deve-lhe suas atenções, seus conselhos; sua experiência é a autoridade que deve guiar a criança". ${ }^{146}$ Quanto ao processo educativo, o autor considera:

Tornai vosso aluno atento aos fenômenos da natureza e logo o tornareis curioso; mas, para alimentar sua curiosidade, nunca vos apresseis em satisfazê-la. Colocai questões ao seu alcance e deixai que ele as resolva. Que nada ele saiba porque lho dissesse, mas porque ele próprio compreendeu; não aprenda ele a ciência, mas a invente. Se alguma vez substituirdes em seu espírito a razão pela autoridade, ele não raciocinará mais e não será mais do que o joguete da opinião dos outros. $^{147}$

Sem contestação, conseguimos noções bem mais claras e bem mais seguras das coisas que aprendemos por nós mesmos do que das que recebemos dos ensinamentos de outrem, e, além de não acostumarmos nossa razão a submeter-se servilmente à autoridade, tornamo-nos mais

\footnotetext{
${ }^{144}$ Ibidem, p. 77.

${ }^{145}$ É interessante notar que, de fato, a natureza parece exercer um poder sobre as crianças. Em determinada situação, onde trabalhava com uma sala extremamente indisciplinada, comecei a fazer o "momento da natureza", onde pesquisávamos alguma curiosidade, discutíamos ou saíamos para observar o entorno da escola; e isso surtiu um efeito bastante significativo no comportamento e no interesse pelos estudos!

${ }_{146}$ ROUSSEU, Emílio, p. 216.

${ }^{147}$ Idem, p. 206.
} 
engenhosos descobrindo relações, unindo idéias, inventando instrumentos do que quando, adotando tudo isso tal como nos é dado, deixamos que nosso espírito se apague na indolência, como o corpo de um homem que, sempre vestido, calçado, servido por seus empregados e levado por seus cavalos, perde no final a força e o uso dos seus membros. ${ }^{148}$

A partir dessa idéia de construção do próprio conhecimento, Rousseau aponta para a necessidade de que, através do bom senso, o educador seja capaz de selecionar os conhecimentos que são realmente importantes para a formação do educando, numa tentativa de não enchê-lo de informações desnecessárias ou insignificantes, mas apresentando-lhe sempre algo que seja interessante e significativo, para que ele se envolva no processo de aprendizagem: "Lembrai sempre que o espírito de minha educação não é ensinar à criança muitas coisas, mas não deixar jamais entrar em seu cérebro idéias que não sejam claras e justas". ${ }^{149}$

E, ainda, quando afirma que não quer fazer de seu aluno um joguete da opinião dos outros ou alguém que se submeta à autoridade sem contestação, vemos implicitamente uma formação voltada para a política, para a vida na sociedade civil, onde é necessário que pense por si próprio, que tenha consciência de seus direitos e deveres, da organização social, para que não seja preciso se submeter aos governantes por ignorância, por falta de informação e formação para a cidadania.

Rousseau, ao apontar a idéia de que em determinado momento da vida, entre 12 e 15 anos, Emílio já tem condições de discernir entre o que lhe é útil ou não, o que lhe convém ou não, afirma ser necessário, para fazer suas escolhas, ter em mente uma espécie de projeção de vida, isto é, é preciso considerar para além das necessidades atuais e ser previdente quanto às necessidades futuras: "Este é o uso da previdência, e da previdência bem ou mal ordenada nasce toda a sabedoria ou toda a miséria humana". ${ }^{150}$

Portanto, estimular o uso da previdência ou bom senso é um meio de fazer com que o educando tenha consciência das conseqüências de suas escolhas e, ainda, saiba que é responsável pelos seus atos. Daí a necessidade de que a relação professor aluno seja estabelecida com base em regras claras e explícitas, propiciando uma oportunidade de vivenciar uma relação pedagógica contratual, isto é, com deveres e direitos claros, assim como suas regras de funcionamento, para que essa vivência seja uma espécie de ensaio para a vida em sociedade.

\footnotetext{
${ }^{148}$ Ibidem, p. 219.

${ }^{149}$ Ibidem, p. 211

${ }^{150}$ Ibidem, p. 221.
} 
Considerando essa idéia de previdência, de consciência a respeito de seus direitos e deveres, assim como do funcionamento de uma sociedade civil - o que só deve ocorrer explicitamente na adolescência - como essenciais para a vida pública, Rousseau aponta para a necessidade de que Emílio, para poder viver bem socialmente, deva conhecer as relações de troca, como a moeda por exemplo, e, portanto, deve ter uma noção real do valor ou da utilidade das coisas, o que remete à necessidade de ter uma profissão, isto é, um ofício em que possa produzir algo com o qual contará para sua sobrevivência: “Trabalhar é um dever indispensável para o homem social". ${ }^{151}$

Desse modo, vemos a importância dada pelo autor ao ato de trabalhar, de ser autosuficiente e útil à sociedade em que se vive. Para Rousseau, é essencial que Emílio seja responsável por si mesmo e capaz de se sustentar na vida em sociedade. Assim, fica claro que ter um trabalho ou um ofício é algo que deve ser estimulado entre os jovens, para que valorizem tanto seu próprio trabalho quanto o dos outros e, ainda, para que desenvolvam habilidades que os levem a ser capazes de, através de uma atividade prática, ganhar seu próprio sustento. E, ainda, para o autor, o ato de trabalhar deve ser visto como um engrandecimento do homem, uma ação que demonstra seu bom caráter, sua honestidade: "Não trabalheis por necessidade, mas por glória". ${ }^{152} \mathrm{E}$, ainda afirma que:

Quem come na ociosidade o que não ganhou por si mesmo rouba-o, e um homem que vive de rendas, que o Estado paga para nada fazer, pouco difere, a meu ver, de um ladrão que vive à custa dos passantes. Fora da sociedade, o homem isolado, não devendo nada a ninguém, tem o direito de viver como lhe agrada; na sociedade, porém, onde vive necessariamente à custa dos outros, develhes em trabalho o preço de seu sustento; isso não admite exceção. (...) Todo cidadão ocioso é um patife. $^{153}$

Não basta escolher uma profissão útil, é também preciso que ela não requeira das pessoas que a exercem qualidades de alma odiosas e incompatíveis com a humanidade. Assim, voltando à primeira palavra, tomemos uma profissão honesta, mas lembremo-nos sempre de que não há honestidade sem utilidade. ${ }^{154}$

\footnotetext{
${ }^{151}$ Ibidem, p. 250.

152 Ibidem, p. 251.

${ }^{153}$ Ibidem, p. 250.

${ }^{154}$ Ibidem, p. 253.
} 
Embora Rousseau afirme que é importante que Emílio deva ter uma profissão vinculada ao trabalho manual, é importante ressaltar que isso não dispensa o desenvolvimento intelectual, pelo contrário, para o autor é fundamental desenvolver tanto as habilidades manuais quanto a capacidade de raciocínio lógico, de inteligência:

É preciso que ele trabalhe como um camponês e pense como filósofo, para não ser tão vagabundo como um selvagem. O grande segredo da educação é fazer com que os exercícios do corpo e do espírito sirvam sempre de descanso uns para os outros. ${ }^{155}$

A capacidade de raciocinar inclui a habilidade de julgar bem. Rousseau afirma que é extremamente importante que Emílio saiba analisar as situações, as coisas e as pessoas ao seu redor para que, através dessa análise, seja capaz de determinar o que deve ou não fazer e como se relacionar com seus concidadãos. Segundo o autor:

\begin{abstract}
A melhor maneira de ensinar a bem julgar é a que mais tende a simplificar as nossas experiências e a poder até mesmo dispensar-nos delas sem incorrer em erro. Donde se segue que, depois de ter verificado por muito tempo as relações dos sentidos um pelo outro, é preciso ainda aprender a verificar as relações de cada sentido por si mesmo, sem necessidade de recorrer a outro sentido; então, cada sensação tornar-se-á para nós uma idéia, e essa idéia sempre será conforme a verdade. (...) Trata-se menos de ensinar-lhe uma verdade do que de mostrar-lhe como se deve agir para sempre descobrir a verdade. ${ }^{156}$
\end{abstract}

Essa capacidade de julgar bem deve ser adquirida até mesmo para que o educando seja capaz de julgar as pessoas ao seu redor quanto às atitudes e experiências que realizam. Desse modo é possível estabelecer um parâmetro de comportamento moral e ético, estabelecendo também exemplos que devem ou não ser seguidos pelos educandos:

Se se tratasse apenas de mostrar aos jovens o homem por sua máscara, não precisaríamos mostrá-

lo, pois eles sempre o veriam. Mas já que a máscara não é o homem e é preciso que seu verniz não os seduza, ao representar-lhes os homens representai-os tais como são, não para que os odeiem,

\footnotetext{
155 Ibidem, p. 261.

${ }^{156}$ Ibidem, p. 265.
} 
mas para que os lamentem e não queiram parecer-se com eles. Este é, na minha opinião, o sentimento mais inteligente que o homem possa ter sobre a sua espécie. ${ }^{157}$

Saiba ele que o homem é naturalmente bom, sinta-o, julgue seu próximo por si mesmo; mas veja ele como a sociedade deprava e perverte os homens; descubra nos preconceitos a fonte de todos os vícios dos homens; seja levado a estimar cada indivíduo, mas despreze a multidão; veja que todos os homens carregam mais ou menos a mesma máscara, mas saiba também que existem rostos mais belos do que a máscara que os cobre. ${ }^{158}$

É preciso, então, fazer com que o aluno desenvolva a habilidade de julgar bem e não, simplesmente, oferecer-lhe verdades prontas. Nesse sentido, se tomarmos esse princípio para pensarmos o processo de aprendizagem em sala de aula, devemos concluir que não se deve oferecer conteúdos extensos e fechados aos alunos, mas propiciar-lhes situações de apreender determinados assuntos, estimulando-os a pensar a respeito. Em outras palavras, é preciso oferecer um ensino dinâmico, no qual o aluno possa construir seu conhecimento, através da pesquisa, por exemplo, mas sem esquecer que as intervenções do educador são essenciais já que, como vimos, ele é quem pode fornecer mais informações sobre os conteúdos, devido à sua bagagem de conhecimentos:

Outra vantagem desse encadeamento de conhecimentos limitados, mas exatos, é mostrar-lhe tais conhecimentos por suas ligações, por suas relações, de colocá-los todos em seu lugar na sua estima e de evitar os preconceitos que a maioria dos homens tem a favor dos talentos que cultivam e contra os que deixaram de lado. Quem vê bem a ordem do todo vê o lugar onde deve estar cada parte; quem vê bem uma parte e a conhece a fundo pode ser um homem douto; o outro é um homem judicioso. E deveis lembrar-vos de que o que nos propomos a adquirir é menos a ciência do que o juízo. ${ }^{159}$

Dessa forma investigativa, Rousseau acredita que estará fazendo com que o aluno raciocine acerca das coisas, o que, para ele, é a mesma coisa que julgar bem. E ainda, afirma que assim poderá ter conhecimentos que são verdadeiramente seus, já que os elaborou através de uma atitude autônoma. Rousseau se mostra contrário à educação tradicional, posto que esta prioriza a

\footnotetext{
${ }^{157}$ Ibidem, p. 310.

${ }^{158}$ Ibidem, p. 311.

${ }^{159}$ Ibidem, p. 245.
} 
memorização em detrimento do raciocínio, gerando, desse modo, conhecimentos supérfluos e artificiais. Quanto ao desenvolvimento da capacidade de bem julgar afirma que:

\begin{abstract}
Desse exercício contínuo deve resultar um vigor de espírito semelhante ao que o corpo ganha com o trabalho e a fadiga. Outra vantagem é que avançamos proporcionalmente às nossas forças. Assim como o corpo, o espírito só carrega o que pode carregar. Quando o entendimento se apossa das coisas antes de depositá-las na memória, o que extrai delas em seguida é dele. Ao passo que, sobrecarregando a memória sem saber, corremos o risco de nunca tirar dela o que seja nosso. (...) Emílio tem poucos conhecimentos, mas os que têm são seus de verdade; nada tem pela metade. ${ }^{160}$
\end{abstract}

Paralelamente a essa capacidade de julgar bem, de adquirir seus conhecimentos através da própria atividade de pesquisar e pensar, está o desenvolvimento da autonomia, que, para Rousseau, é essencial para a vida em sociedade, que demanda o pensamento e a atitude autônoma, isto é, a capacidade de, mesmo frente à sociedade corrompida e degenerada, manter-se bom e seguindo a marcha da natureza, ou seja, ser capaz de controlar as paixões artificiais, tendo sempre atitudes positivas independente das atitudes dos outros: "E que ele julgue por si mesmo, é assim que aprenderá a conhecer os homens. Se o julgamento do autor [educador] guiá-lo sem parar, ele apenas verá através dos olhos de outro, e, quando esses olhos lhe faltarem, nada mais verá". 161

Rousseau afirma que para bem observar os homens e, conseqüentemente, compreender a sociedade, é preciso "um grande interesse por conhecê-los, uma grande imparcialidade para julgá-los, um coração suficientemente sensível para compreender todas as paixões humanas e suficientemente calmo para não experimentá-las". ${ }^{162}$

Nesse sentido, acredita que enquanto Emílio observa as atitudes das pessoas na vida em sociedade, é necessário que perceba o quanto as paixões são prejudiciais aos homens, querendo manter-se afastado delas:

Emílio mal se reconhecerá nos estranhos objetos que impressionarão seu olhar durante esses novos estudos, mas saberá descartar de antemão a ilusão das paixões antes que elas nasçam; e, vendo que

\footnotetext{
${ }^{160}$ Ibidem, p. 268.

${ }^{161}$ Ibidem, p. 314

162 Ibidem, p. 323.
} 
em todos os tempos elas cegaram os homens, será prevenido sobre como poderão cegar a ele por sua vez, se um dia entregar-se a elas. ${ }^{163}$

A principal paixão que deve ser evitada, segundo o autor, é o amor-próprio: "Esse é o erro que mais devemos temer, porque é o mais difícil de se destruir". ${ }^{164}$ Contrário ao amor-de-si, paixão natural que faz com que o homem se cuide, se preserve, o amor próprio faz com que se compare com os outros, julgando-se melhor, o que impede a piedade ou a capacidade de se colocar no lugar dos que sofrem, priorizando o bem estar da espécie, o bem-estar geral, que, por sua vez, é essencial para vida pacífica e solidária em sociedade.

Até o momento tratamos dos princípios educativos apontados por Rousseau desde o nascimento até a entrada na adolescência, posto que são preceitos essenciais na formação do homem e do cidadão, independentemente da idade em que a criança se encontra. $\mathrm{O}$ autor deixa claro que o processo educativo se dá desde o nascimento, demonstrando que os primeiros anos de vida são uma espécie de alicerce para a formação do adulto.

Desse modo, é importante apontarmos os primeiros princípios demonstrados por ele na infância para prosseguir enfatizando aqueles que devem ser desenvolvidos na adolescência, que é o principal momento da educação e, ainda, o mais delicado: "Não abandones por mais nenhum instante o leme, ou tudo estará perdido". ${ }^{165}$ Rousseau afirma que nesse período, os princípios estabelecidos na infância, momento de certa inocência em relação às paixões, devem ser reforçados, para garantir o sucesso da educação:

Eis, portanto, outra vantagem da inocência prolongada: tirar proveito da sensibilidade nascente para jogar no coração do jovem adolescente as primeiras sementes da humanidade; vantagem muito mais preciosa quanto esse é o único tempo da vida em que os mesmos cuidados podem ter um verdadeiro sucesso. ${ }^{166}$

Para pensarmos como deve se dar o processo educativo a partir da adolescência, é preciso lembrar que é neste momento que o educando começará sua vida social, seu relacionamento com

\footnotetext{
163 Ibidem, p. 321.

${ }^{164}$ Ibidem, p. 324

165 Ibidem, p. 272.

${ }^{166}$ Ibidem, p. 285.
} 
os outros, que pressupõe o afloramento da moralidade e, portanto, nesse momento "o estudo que convém ao homem é o dessas relações". ${ }^{167}$

A partir desse momento, em que o jovem começa sua vida em sociedade, um dos primeiros princípios apontados por Rousseau se refere à importância da verdade. Ele afirma que nunca se deve mentir para o educando, para que ele não aprenda a mentir ou perca a confiança em relação ao educador. Quando surgir uma pergunta cuja resposta o educador não saiba ou que não acha conveniente responder, é melhor que não responda, mas jamais deve mentir: “... perguntas que não somos obrigados a resolver não exigem que enganemos quem as fez; mais vale impor-lhe silêncio que responder mentindo". ${ }^{168}$ A mentira pode arruinar a relação pedagógica:

\footnotetext{
Sejam vossas respostas sempre graves, curtas, decididas, sem jamais parecer hesitar. Não preciso acrescentar que devem ser verdadeiras. Não podemos ensinar às crianças o perigo de mentir para os adultos sem sentir, da parte dos adultos, o perigo maior de mentir para as crianças. Uma única mentira confirmada do mestre para o aluno arruinaria para sempre todo o fruto da educação. ${ }^{169}$
}

Rousseau afirma que não se deve mentir para o jovem nem mesmo em relação aos sofrimentos existentes na sociedade em que vive, por exemplo, em relação à morte ou as doenças. Pelo contrário, acredita que esses sofrimentos fazem com que o jovem coloque-se no lugar dos outros, fazendo com que a piedade - sentimento natural no selvagem, que faz com que ele respeite ao outro porque se coloca em seu lugar, preservando a espécie - continue existindo no estado civil, para que haja beneficência e bondade:

Assim nasce a piedade, primeiro sentimento relativo que toca o coração humano conforme a ordem da natureza. Para tornar-se sensível e piedosa, é preciso que a criança saiba que existem seres semelhantes a ela que sofrem o que ela sofreu, que sentem as dores que ela sentiu e outras que deve ter idéia de que também poderá sofrer. (...) Assim, ninguém se torna sensível a não ser quando sua imaginação se excita e começa a transportá-lo para fora de si. (...) Isso significa, em outras palavras, excitar nela a bondade, a humanidade, a comiseração, a beneficência, todas as paixões atraentes e doces que agradam naturalmente aos homens e impedir que nasçam a inveja, a cobiça, o

\footnotetext{
${ }^{167}$ Ibidem, p. 275.

${ }^{168}$ Ibidem, p. 279.

${ }^{169}$ Ibidem, p. 279-80.
} 
ódio, todas as paixões repugnantes e cruéis, que, por assim dizer, tornam a sensibilidade não somente nula, mas negativa, e fazem o tormento de quem as experimenta. ${ }^{170}$

Para ser capaz de se colocar no lugar do outro, tendo a sensibilidade em torno de sua situação, é importante que Emílio conheça o funcionamento da sociedade em que vive e assim a analise enquanto estado civil, inclusive quanto às diferenças sociais:

Para guiá-lo nessa busca, depois de lhe ter mostrado os homens pelos acidentes comuns à espécie, é preciso agora mostrar-lhos por suas diferenças. Aqui se dá a medida da desigualdade natural e civil, assim como o quadro de toda a ordem social. ${ }^{171}$

E no que se refere ao comportamento do educando em relação à verdade, Rousseau acredita que é necessário agir sempre de acordo com sua consciência, com aquilo que acredita, sendo fiel aos seus princípios e valores morais:

Se algum dia teus talentos cultivados te colocarem em condições de falar aos homens, nunca lhes fale senão de acordo com tua consciência, sem te incomodar em ver se te aplaudem. (...) Permanece sempre firme no caminho da verdade, ou do que te parecer sê-lo na simplicidade do teu coração, sem te afastares dele por vaidade ou por fraqueza. ${ }^{172}$

Rousseau afirma ainda que ser um homem que usa de bom senso e que tem suas atitudes voltadas para o bom caráter deve ser uma condição de honra: "Emílio é um homem de bom senso, e não quer ser outra coisa; por mais que se queira insultá-lo com essa qualificação, ele sempre se sentirá honrado com ela". ${ }^{173}$

Rousseau aponta vários princípios educativos como importantes na formação de Emílio, mas enfatiza três preceitos que considera fundamentais. São eles a necessidade, a utilidade e a liberdade.

Em relação à necessidade, Rousseau afirma que devemos oferecer ao educando somente aquilo de que ele realmente precisa, sem ceder aos seus caprichos ou vontades fundadas em mimos. Nesse preceito, que reitera a idéia de dependência das coisas, podemos ver um enfoque

\footnotetext{
${ }^{170}$ Ibidem, p. 289-90.

${ }^{171}$ Ibidem, p. 309.

172 Ibidem, p. 428.

${ }^{173}$ Ibidem, p. 467.
} 
em relação à educação para a vida social, quando o autor liga a idéia de dominação à de necessidade, afirmando que os desejos do educando não podem ser considerados como ordens, como um motivo para que ele - ou mesmo o educador - possa exercer um poder ou a dominação sobre outros: "Nada concedei a seus desejos porque ela [a criança] o pede, mas porque precisa. Que ela não saiba o que é obediência quando age, nem o que é dominação quando agem por ela". 174

Rousseau acredita que é preciso ser firme nesse princípio, pois ceder aos caprichos e necessidades artificiais pode levar o educando a acreditar que pode negociar em qualquer situação, criando necessidades para suprir todos os seus desejos, ao passo que, se desde pequeno aprende que há coisas necessárias que podem e devem ser consentidas e existem outras que não são necessárias e devem ser negadas ou proibidas, ele se conscientiza e quer somente o que é realmente necessário:

É preciso, então, distinguir com cuidado a verdadeira necessidade, a necessidade natural, da necessidade de fantasia que começa a nascer, ou então daquela que provém da superabundância da vida que falei. (...) Se a necessidade a fez falar, deveis sabê-lo e fazer imediatamente o que ela pede, mas ceder algo pelas lágrimas e provocá-la para que as derrame, é ensinar-lhes a duvidar de vossa boa vontade e a acreditar que a importunidade pode mais sobre vós do que a benevolência. Se ela não acreditar que sois bons, logo se tornará má; se acreditar que sois fraco, logo se tornará teimosa. É importante que sempre concedais ao primeiro sinal o que não quereis recusar, não sejais pródigo na recusa, mas não a revogueis jamais. ${ }^{175}$

E, por sua vez, esse princípio garante que, na adolescência, com o surgimento das paixões artificiais, terá condições de distinguir o necessário do supérfluo, impedindo a revolta e a rebeldia típicas dessa fase:

Assim, a criança que só precisa querer para conseguir acredita ser a proprietária do universo; considera todos os homens seus escravos e, quando finalmente somos forçados a lhe recusar alguma coisa, ela, acreditando que tudo é possível quando manda, toma essa recusa como um ato de rebeldia. ${ }^{176}$

\footnotetext{
${ }^{174}$ Ibidem, p. 78.

175 Ibidem, p. 79.

${ }^{176}$ Ibidem, p. 81 .
} 
$\mathrm{O}$ autor acredita que só obedecendo à lei da necessidade o homem viverá bem, tanto em relação a si mesmo quanto em relação à sociedade:

\begin{abstract}
Assim, se quiseres viver feliz e sabiamente, dá teu coração apenas à beleza imperecível; que tua condição limite os teus desejos e teus deveres vençam tuas inclinações; estende a lei da necessidade a coisas morais, aprende a perder o que te pode ser tirado; aprende a deixar tudo quando a virtude o ordena, a colocar-te acima dos acontecimentos, a afastar deles o teu coração antes que eles o dilacerem, a ser corajoso na adversidade, para nunca seres miserável, a ser constante em teu dever, para nunca seres criminoso. Então, serás feliz apesar da fortuna e prudente apesar das paixões. ${ }^{177}$
\end{abstract}

Quanto à utilidade, afirma que é importante, para o educador, que saiba selecionar as coisas que são realmente úteis aos educandos, cuidando para não enchê-los de conhecimentos supérfluos e inúteis:

Há, portanto, uma escolha das coisas que devemos ensinar, assim como do tempo próprio para ensiná-las. Dos conhecimentos que estão ao nosso alcance, uns são falsos, outros são inúteis e outros servem para alimentar o orgulho de quem os tem. (...) Não se trata de saber o que existe, mas apenas o que é útil. ${ }^{178}$

Rousseau acredita que é importante ensinar à criança o que é útil, para que esse princípio educativo seja um parâmetro das atitudes desta, tomando como base o seu próprio bem-estar:

\begin{abstract}
Assim que chegamos a dar ao nosso aluno uma idéia da palavra útil, temos mais um grande meio para educá-lo, pois essa palavra o impressiona muito, dado que tem para ele apenas um sentido relativo à sua idade e que ele vê claramente a sua relação com seu bem-estar atual. ${ }^{179}$
\end{abstract}

Esse preceito é essencial para que a criança tenha contato somente com coisas que são próprias para a sua idade ou para o seu nível de desenvolvimento, sem que o processo educativo vise transformá-la num pequeno adulto, idéia criticada e rejeitada por Rousseau:

\footnotetext{
${ }^{177}$ Ibidem, p. 629.

${ }^{178}$ Ibidem, p. 204.

${ }^{179}$ Ibidem, p. 223.
} 
É importante que um adulto saiba muitas coisas cuja utilidade uma criança não é capaz de entender; mas será preciso e possível uma criança aprender tudo o que é importante que um adulto saiba? Procurai ensinar à criança tudo o que é útil para a sua idade e vereis que todo o seu tempo estará ocupado. $^{180}$

Desse mesmo modo Rousseau afirma ser importante que Emílio, ou o educando, saiba as coisas no momento adequado, de acordo com o seu desenvolvimento e, digamos, capacidade de aprendizagem. É importante estabelecer esse princípio para que, ao chegar na adolescência, o jovem seja capaz de sentir as paixões e fazer uma análise em torno delas, determinando aquelas atitudes que são necessárias e úteis, para segui-las ou eliminá-las, preservando a bondade natural e continuando na marcha da natureza.

Entre os princípios destacados por Rousseau, desde a primeira infância até a maturidade, a liberdade é o mais enfatizado:

O único que faz a sua vontade é aquele que não precisa para tanto colocar o braço de outrem na ponta dos seus. Segue-se daí que o primeiro de todos os bens não é a autoridade, mas a liberdade. O homem verdadeiramente livre só quer o que pode e faz o que lhe agrada. Eis a minha máxima fundamental. Trata-se apenas de aplicá-la à infância e todas as regras da educação decorrerão dela. $^{181}$

Rousseau afirma que é importante que a formação do educando seja voltada para a liberdade, pois é por meio dela que pode, ao tornar-se adulto, agir com consciência e responsabilidade em relação às suas escolhas, pautando-as sempre no que prescreve a natureza. Assim, não precisará de outros para o servir ou determinar coisas acerca de sua vida, pelo contrário, terá autonomia e será sempre dono de si mesmo:

Preparai à distância o reinado de sua liberdade e o uso de suas forças, deixando em seu corpo o hábito natural, colocando-a em condições de sempre ser senhora de si mesma e de fazer em todas as coisas a sua vontade, assim que a tiver. ${ }^{182}$

\footnotetext{
${ }^{180}$ Ibidem, p. 222.

${ }^{181}$ Ibidem, p. 76.

${ }^{182}$ Ibidem, p. 47.
} 
É importante considerar que, para Rousseau, a liberdade não pode ser entendida como "fazer o que bem entender", pelo contrário, para ele a liberdade está sempre subordinada ao bom senso e ao bem-estar comum, como quando diz respeito à vontade geral. Por isso, afirma que a felicidade da criança e do homem está no uso da liberdade:

\begin{abstract}
Antes que os preconceitos e as instituições humanas tenham alterado nossas inclinações naturais, a felicidade das crianças e dos homens consiste no uso de sua liberdade. Mas, nos primeiros, esta liberdade é limitada pela fraqueza. (...) As crianças, até mesmo no estado de natureza, só gozam de uma liberdade imperfeita, semelhante àquela de que gozam os homens no estado civil. Cada um de nós, não podendo dispensar os outros, volta a ser, a esse respeito, fraco e miserável. Éramos feitos para sermos homens; as leis e a sociedade voltaram a mergulhar-nos na infância. ${ }^{183}$
\end{abstract}

Como vemos, embora o autor afirme que nossa felicidade depende do uso que fazemos de nossa liberdade, isto é, nosso bem-estar depende das nossas escolhas, das nossas atitudes, como, por exemplo, ceder ou não às paixões artificiais, faz uma ressalva, apontando a idéia de que, no estado civil, vivemos todos uma liberdade limitada pela interdependência existente entre todos os cidadãos. Por isso, considera que o uso da liberdade deve ser regrado pelo bom senso, prevalecendo a vontade geral, que, por sua vez, prima pelo bem-estar comum:

Não é suficiente dizer aos cidadãos que sejam bons, é preciso ensiná-los a ser; e o próprio exemplo,
que neste sentido é a primeira lição, não é o único meio que se deve empregar - o amor à pátria é o
mais eficaz; porque, como já disse, todo homem é virtuoso, quando sua vontade particular está em
conformidade com a vontade geral. E de bom grado quer aquilo que querem as pessoas que ama. ${ }^{184}$

Rousseau enfatiza ainda a idéia de que mesmo estando num estado em que muitos homens não obedecem às leis da sociedade civil, o homem de bem - no caso, Emílio - as respeita por considerá-las lei positiva, que está prescrita no seu coração e na sua consciência: "[Emílio] diz a sua opinião sem combater a de ninguém, porque ama a liberdade acima de todas as coisas e a franqueza é um de seus mais belos direitos". ${ }^{185}$ Isto é, independente da atitude dos outros em relação ao uso que fazem de sua liberdade - por exemplo, quando se deixam degenerar, agindo de acordo com vícios - o educando deve ter como parâmetro o bom senso na tomada de suas

\footnotetext{
${ }^{183}$ Ibidem, p. 77.

${ }^{184}$ ROUSSEAU, Discurso sobre a Economia Política, p. 34.

${ }^{185}$ ROUSSEAU, Emílio, p. 463.
} 
decisões, para que sempre prevaleçam seus valores morais, suas próprias crenças. Esse bom uso da liberdade seria, grosso modo, estar sempre atento às leis da natureza, que existem mesmo num estado corrompido, onde não existam as leis civis:

... as leis eternas da natureza e da ordem existem. Para o sábio, são como uma lei positiva; são escritas no fundo do seu coração pela consciência e pela razão; é a elas que deve sujeitar-se para ser livre, e só é escravo quem age mal, pois fá-lo sempre contra a vontade. A liberdade não está em nenhuma forma de governo, ela está no coração do homem livre; ele a carrega consigo por toda a parte. $^{186}$

Considerando a importância de formar o adolescente para que consiga ultrapassar essa complexa fase da vida sem se deixar levar pelas paixões artificiais, é essencial frisar a idéia de que os princípios educativos de Rousseau servem para iluminar a prática educativa, fornecendo aos educadores condições de discernir sobre como deve se dar o processo educativo. Para o autor, resumidamente, é importante formar o homem virtuoso, ou seja, que tenha construído seus valores através desses princípios:

Que é então o homem virtuoso? É aquele que é capaz de vencer suas afeições, pois então ele segue a razão, a consciência; faz seu dever, mantém-se na ordem e nada o pode afastar dela. Até agora só eras livre em aparência; tinhas somente a liberdade precária de um escravo a quem nada foi ordenado. Sê, agora, livre de fato; aprende a te tornares teu próprio senhor; governa teu coração, Emílio, e serás virtuoso. ${ }^{187}$

${ }^{186}$ Idem, p. 669.

${ }^{187}$ Ibidem, p. 627. 


\section{PERSPECTIVAS PARA UMA EDUCAÇÃO CIDADÃ}

Por fim, neste último capítulo, trata-se de apontar algumas perspectivas em relação à educação para a cidadania. Ao considerar as possibilidades da efetivação de uma educação cidadã, é preciso evidenciar a necessidade de que a formação dos professores, bem como suas condições de trabalho, sejam analisadas e direcionadas para que os educadores sejam capacitados e possam oferecer essa formação.

Isto é, quando se trata de educação, mesmo que este não seja o foco da pesquisa, é importante apontar para a necessidade de uma formação adequada dos educadores, bem como para o fato de que é preciso oferecer-lhes condições dignas de trabalho, ou melhor, condições que possibilitem uma boa formação aos educandos, especialmente no que diz respeito à cidadania.

$\mathrm{O}$ interesse por educação, para a maioria dos educadores e pessoas envolvidas nesse processo, é comumente manifesto através da crença de que a salvação está na educação voltada para a cidadania, como é possível notar tanto em conversas informais entre os professores, quanto em reuniões pedagógicas ou nos próprios documentos oficiais, como os PCNs. Muitos apontam uma reforma educacional no país como a possibilidade mais viável para que as mudanças fossem significativas, para que se realizasse, de fato, melhorias tanto no aspecto social quanto no humano.

Pinsky aponta uma tentativa para começar a solucionar o problema, o que se daria por meio de uma reforma no que diz respeito à formação dos professores:

\footnotetext{
Nossa única chance é ousar. Interromper durante um semestre, ou mesmo um ano (...) [os cursos] nas áreas ligadas ao ensino fundamental e organizar, sob a orientação do ministério da Educação, um curso enérgico de capacitação para todos os professores brasileiros. (...) O país ficaria de pernas para o ar durante um ano, ao fim do qual teríamos um quadro docente bem mais capacitado. É claro que o programa teria que ser permanente, exigindo acompanhamento cuidadoso, formação de bibliotecas escolares para alunos e professores, política coerente de salários e benefícios e por aí a fora". 188
}

${ }^{188}$ PINSKY, p. 104. 
Considerando essa realidade em relação a educação atual, ao entrar em contato com os textos pedagógicos de Rousseau, analisando suas idéias, é possível evidenciar a importância do seu pensamento, que é fundamental para que o processo educacional seja formador do homem e do cidadão, o que desperta grande interesse, já que educar para a cidadania é o desejo e o objetivo global quando o assunto é educação. E, ainda, é interessante notar como suas idéias acerca da política também são essenciais para constituirmos uma sociedade mais justa e democrática, como vemos no Contrato, por exemplo, pelo conceito de vontade geral.

Embora pareça utopia falar numa cidade onde haja leis que retratem efetivamente os direitos e deveres dos cidadãos e sejam cumpridas imparcial e incondicionalmente, é importante pensar que, apesar da crise, é preciso pensar em resolver ou amenizar essa situação e que, como afirma Rousseau, mesmo que não tenhamos uma cidade, temos pelo menos uma pátria, pela qual devemos zelar, o que, para o autor, pode se dar através da educação:

\begin{abstract}
Mas todas essas precauções se tornam insuficientes, se não se alarga ainda mais a análise. Termino esta parte da economia pública por onde deveria tê-la começado. A pátria não pode subsistir sem a liberdade, nem a liberdade sem a virtude, nem a virtude sem os cidadãos; isso é possível quando os cidadãos são educados para tal, caso contrário têm-se apenas escravos ruins, começando pelos próprios chefes de Estado. ${ }^{189}$
\end{abstract}

É claro que a questão é bastante complexa. Educar para a cidadania, prevendo a existência de uma verdadeira cidade, no sentido de pólis, não é algo simples e fácil de se realizar. Mas por outro lado, é algo urgente de se pensar. É preciso que os educadores pensem, que reflitam profundamente sobre as possibilidades de direcionar a formação dos jovens para a consciência política, que não implica somente conhecer seus direitos e deveres, a estrutura e o funcionamento político e social do país, mas acima de tudo, ver-se enquanto parte desse corpo político, expressando seus interesses através da vontade geral, que deve prever o bem-estar geral e, ainda, buscar isso nas realizações práticas e concretas.

A educação é uma espécie de ruptura com a sociedade degenerada que temos atualmente, uma possibilidade de, por meio de um processo educativo de qualidade, formar os jovens para a moralidade e, principalmente, para a cidadania. Como afirma Pissarra:

${ }^{189}$ ROUSSEAU, Discurso sobre Economia Política, p. 39. 
E quando a sociedade já estiver corrompida? O que é possível fazer? Apenas salvar um ou outro indivíduo - como mostra o Emílio. Portanto, a educação é a única "revolução" proposta por Rousseau: age sobre as sociedades já formadas (mesmo que limitadamente) e age sobre o cidadão ainda em formação, sendo esta sua grande função. ${ }^{190}$

Pinsky, apontando a importância da educação escolar, também acredita que, através da formação para a cidadania, possa haver uma espécie de revolução:

\footnotetext{
Ora, iniciar um trabalho educacional sistemático, para que o povo adquira poder político e efetivo, participando diretamente das grandes decisões públicas, ao invés de ter sua vontade manipulada eleitoralmente; suscitar em todos nós a consciência da importância dos direitos humanos de caráter social (a começar pelo direito à educação) - tudo isto não é apenas "um choque educacional”. É uma revolução. A verdadeira, enfim". ${ }^{191}$
}

Mas Rousseau acrescenta um elemento que torna mais difícil a possibilidade de sucesso, dizendo que só podemos dirigir a educação dos homens e, parcialmente, pois é impossível controlar as ações de todos que cercam a criança, de onde vem a necessidade de contar com a sorte. Nesse sentido, para educar adolescentes para cidadania seria necessário que a família e todas as pessoas que os cercam - especialmente os professores - defendessem a mesma idéia do que seja educação, política e cidadania, entre outros conceitos.

Daí constata-se que é uma utopia pensar em praticar Rousseau, posto que a cidade que temos na realidade atual demonstra uma crise de valores, desrespeita suas leis e, muitas vezes, aqueles que defendem uma formação para a moralidade e a cidadania real (lembremos o referencial grego), são tidos como seres ultrapassados, como modelos que não servem mais.

Isto é, como vivemos numa sociedade na qual não existem princípios únicos ou pelo menos equivalentes no que diz respeito à educação das crianças e dos jovens, encontramos muitas dificuldades em pensar uma educação que se volte para a formação cidadã, e como a educação descrita no Emílio não se direciona para uma prática pedagógica, resta a possibilidade de nos apropriarmos dos princípios rousseaunianos para estabelecermos um referencial acerca dessa educação.

\footnotetext{
${ }^{190}$ PISSARRA, p. 72.

${ }^{191}$ PINSKY, P. 14.
} 
Ou ainda, como não se trata simplesmente, de aplicar a teoria rousseauísta em sala de aula, na educação formal, é possível fazer dos ideais de Rousseau um referencial teórico para que, apoiados em seus princípios educativos, os educadores possam analisar sua realidade com mais precisão, através de um bom senso bastante rígido, apontar diretrizes de ação que visem ao objetivo de educar para a cidadania e traçar planos para se alcançar essas metas.

Para enfatizar a idéia, não se trata de considerar o Emílio como um manual ou guia para educadores - mesmo porque é preciso considerar, além dos propósitos do autor (que não era de escrever um guia), a temporalidade da obra - mas tomar os princípios apontados por ele como essenciais para a formação do educando, como luz para nortear a reflexão dos educadores, fazendo com que a prática tenha esse referencial.

Em sua Introdução do Emílio, Launay aponta a adolescência como o período em que há motivação para se pensar a educação como algo diferente, inovador: “...o livro IV talvez seja o mais bem composto dos cinco: a sua estrutura (...) [está baseada] na mutação brusca da puberdade, à qual corresponde a mutação brusca das motivações da educação". É preciso considerar então a adolescência como um momento em que pode haver mudanças significativas na formação do homem.

Nesse sentido, tomando o educando como parte central do processo educativo, Rousseau inicia o prefácio do seu Tratado de Educação, recomendando aos educadores que conheçam seus alunos, pois é só a partir desse pressuposto que terão boas condições de efetivar o processo educativo: "Começai, pois, por melhor estudar vossos alunos, pois com toda certeza não os conheceis; ora, se lerdes este livro dentro desta perspectiva, creio que ele não carecerá de utilidade para vós". ${ }^{192}$ Em outras palavras, as idéias apresentadas no decorrer da obra servem para que os educadores reflitam sobre quem são seus alunos, analisando-os e determinando quais atitudes serão eficazes em sua educação.

Mas o que seria, exatamente, conhecer os homens - ou, no caso, os alunos -, quais características devem ser observadas? Rousseau afirma que para bem observar os homens é necessário "um grande interesse por conhecê-los, uma grande imparcialidade para julgá-los, um coração suficientemente sensível para compreender todas as paixões humanas e suficientemente calmo para não experimentá-las". ${ }^{193}$

\footnotetext{
${ }^{192}$ ROUSSEAU, Emílio, p. 04.

${ }^{193}$ Idem, p. 323.
} 
Nesse sentido, fica evidente a responsabilidade do educador em relação ao processo educativo, é por meio dele que os educandos terão acesso tanto às informações culturais, históricas, científicas etc, quanto a muitos valores morais que são essenciais para a formação do jovem e, sobretudo, à formação política, como vimos através dos princípios educativos expostos por Rousseau durante o Emílio. Por outro lado, embora exista de fato grande responsabilidade por parte do educador, é preciso lembrar que, para Rousseau, todas as pessoas que têm contato com a criança ou com o jovem, são educadores, portanto, os pais, a família, a comunidade escolar, todos são responsáveis pela qualidade da educação.

Lembrando que, mesmo quando há o compromisso por parte de todos os educadores em ter atitudes mais corretas possíveis para que haja eficácia no processo educativo, não significa afirmar que se trata de um empreendimento cuja realização seja facilmente alcançada, ou de afirmar que quaisquer ideais são alcançáveis, mas de estabelecer o compromisso, como aponta Rousseau, de fazer o melhor possível, de tentar se aproximar ao máximo da efetivação desses ideais: "Mostro o alvo que devemos propor-nos; não digo que possamos alcançá-lo, mas sim que aquele que mais se aproximar dele será o mais bem-sucedido". 194

Essa aproximação da realização dos objetivos da educação é um trabalho a longo prazo, que pressupõe um projeto contínuo e bem direcionado, desde o nascimento até a maturidade, pois somente desse modo é que pais e educadores falarão a mesma língua e perseguirão as mesmas metas.

Rousseau acredita que o processo educativo obtém sucesso quando há o compromisso com a instrução e com a formação do educando, isto é, com a educação formal e informal, de modo que o educador precisa auxiliar nesse percurso, levando o aluno a construir sua própria aprendizagem:

O talento de instruir é fazer com que o discípulo encontre prazer na instrução. Ora, para isso, seu espírito não deve permanecer tão passivo diante de tudo o que lhe disserdes que não tenha absolutamente nada a fazer para vos compreender. É preciso que o amor-próprio do professor deixe sempre algum espaço para o seu; é preciso que ele possa pensar: Eu compreendo, eu entendo, eu ajo, eu me instruo. ${ }^{195}$

\footnotetext{
${ }^{194}$ Ibidem, p. 93.

${ }^{195}$ Ibidem, p. 329.
} 
Desse modo, fica evidente o quanto é necessário que o educador seja dinâmico, que envolva o aluno no processo de ensino e aprendizagem, levando-o a pensar e construir seu conhecimento de modo autônomo. Para tanto, Rousseau afirma que é preciso que o educador tenha uma postura que demonstre sua autoridade, mas sem ser autoritário no sentido de querer impor as coisas:

O que há de melhor e de mais natural: ser simples e verídico como ele; adverti-lo sobre os perigos que corre; mostrá-los claramente, sensivelmente, mas sem exagero, sem mau humor, sem ostentação pedantesca e, sobretudo, sem lhe oferecer os conselhos como ordens, até que se tornem ordens e que o tom imperioso seja absolutamente necessário. ${ }^{196}$

Rousseau enfatiza ainda a importância de que o educador cuide para não cair no excesso de exposições orais pedantes, de discursos que não mostrem as ligações entre as coisas que quer ensinar, mas que todo assunto tenha um motivo claro para ser ensinado, uma utilidade em relação à sociedade civil:

A arte do mestre consiste em nunca deixar que suas observações se entorpeçam sobre minúcias que não se relacionam com nada, mas em aproximá-lo continuamente das grandes relações que um dia deverá conhecer para bem julgar sobre a boa ou a má ordem da sociedade civil. ${ }^{197}$

Entre outras características, é importante notar ainda que, como vimos nos princípios educativos, a capacidade de bem julgar, de ter um raciocínio lógico e preciso são apontados por Rousseau como essenciais para a formação do educando. $\mathrm{O}$ autor resume o educando bem formado da seguinte forma:

Considerai o meu Emílio, com vinte anos completos, bem formado, bem constituído de espírito e de corpo, forte, sadio, disposto, destro, robusto, cheio de juízo, de razão, de bondade, de humanidade, com bons costumes, bom gosto, amante do belo, fazedor do bem, livre do império das paixões cruéis, sem o jugo da opinião, mas submisso à lei da sabedoria e dócil à voz da amizade; dono de todos os talentos úteis e de vários talentos agradáveis, pouco preocupado com as riquezas,

\footnotetext{
${ }^{196}$ Ibidem, p. 327.
}

${ }^{197}$ Ibidem, p. 241. 
carregando seu recurso na ponta dos braços e sem medo de não ter pão, aconteça o que acontecer. $^{198}$

Para Rousseau, o jovem bem formado, ao chegar próximo da maturidade, apresenta características que, indubitavelmente, foram desenvolvidas através dos princípios educativos expostos no decorrer do Emílio. Tal como, por exemplo, quando diz que Emílio é pouco apegado às riquezas. Isso se dá por meio do princípio de utilidade, isto é, o educando só valoriza aquilo que lhe é útil, e não o supérfluo. Ou ainda, quando afirma que é livre do império das paixões cruéis, essa característica é alcançada através da educação negativa.

Enfim, nessa descrição do Emílio, fica evidente que os princípios apontados pelo autor são, de fato, essenciais para pensarmos uma educação de qualidade, para nos oferecer um norte a respeito da educação que queremos desenvolver com nossos educandos.

Em outras palavras, Emílio não deve ser impedido de ter contatos com a sociedade degenerada, bem como com os indivíduos "formados" a partir dessa realidade, ao contrário, deve viver e conviver com seus concidadãos, mas considerando a importância de que, por meio da educação negativa e de princípios que norteiam para a moralidade, possa se manter imune às paixões artificiais:

\footnotetext{
Mas considerai primeiro que, querendo formar o homem da natureza, não se trata por isso de fazer dele um selvagem e de relegá-lo ao fundo dos bosques, mas, envolvido no turbilhão social, basta que ele não se deixe arrastar nem pelas paixões nem pelas opiniões dos homens; veja ele pelos seus olhos, sinta pelo seu coração; não o governe nenhuma autoridade, exceto a de sua própria razão.(...) O mesmo homem que deve permanecer estúpido nas florestas deve tornar-se razoável e sensato nas cidades, se permanecer como mero espectador. ${ }^{199}$
}

É interessante notar que desenvolver esses princípios não é algo que se dê automaticamente. Pelo contrário, o educador, além de conhecer bem a clientela com a qual vai trabalhar, deve estar consciente e seguro do que e como vai ensinar, de quais estratégias poderão levá-lo a alcançar o desenvolvimento desses preceitos. É claro que também é necessária a participação do próprio educando. Ele deve ser estimulado e levado a se interessar pelo processo de ensino e aprendizagem, através da clareza em relação aos próprios princípios. Isto é, quando

\footnotetext{
${ }^{198}$ Ibidem, p. 587-8.

${ }^{199}$ Ibidem, p. 339.
} 
os objetivos ficam claros e os alunos vêem a utilidade dos conteúdos na vida prática, se envolvem naturalmente.

Quanto ao desenvolvimento desse interesse e comprometimento por parte do aluno, é um trabalho gradativo, aos poucos os alunos vão se envolvendo e valorizam o processo. Rousseau afirma que: "O homem não começa facilmente a pensar; mas, assim que começa, não pára mais. Quem já pensou pensará sempre, e, uma vez exercitado na reflexão, o entendimento não poderá mais permanecer em repouso". ${ }^{200}$

Isto é, ao estimular o aluno à reflexão, ao pensamento crítico, lógico e profundo, o educador estará lhe proporcionando uma habilidade que possibilitará a aprendizagem de inúmeras informações relativas aos conhecimentos históricos, científicos, culturais etc. E, ainda, possibilitará que o educando reflita sobre as situações cotidianas, construindo seus próprios valores morais, as quais automaticamente influenciarão na sua formação política.

É claro que não se trata de colocar nas mãos dos professores toda a responsabilidade pelo processo educativo, desconsiderando a realidade vigente no que diz respeito às suas condições de trabalho, como a questão salarial, as condições de formação, o número de alunos por sala de aula, a infra-estrutura precária das escolas, dentre outros fatores. É sabido que as condições de trabalho do professorado brasileiro são um problema bastante relevante. Mas essa situação não pode ser tomada como desculpa para não haver envolvimento e compromisso dos educadores. Pelo contrário, é preciso aceitar o desafio, mostrar qualidade e exigir as mudanças necessárias. Isso, por si só, já seria um exemplo de organização política para os educandos:

\begin{abstract}
Assim, vemos que, diante de novos desafios colocados à escolarização dos jovens, o próprio papel do professor precisa ser melhor discutido. Ao que tudo indica este papel vem sofrendo transformações e ao professor são dirigidas novas demandas ligadas não apenas ao ensino dos conteúdos, mas também a uma série de valores e atitudes. Equacionar melhor essas demandas é tarefa que certamente envolve os próprios professores, mas também diz respeito às políticas educacionais e à formação oferecida aos profissionais da educação. ${ }^{201}$
\end{abstract}

Dessa forma, não se trata de desconsiderar a crise educacional atual, mas apesar dela, se responsabilizar pela busca de uma educação voltada para a formação cidadã dos jovens. É preciso criar mais vínculos entre toda a comunidade escolar - pais, professores, alunos, diretores etc -,

\footnotetext{
${ }^{200}$ Ibidem, p. 339.

${ }^{201}$ CORTI e SOUZA, p. 135.
} 
possibilitando um diálogo principalmente entre a escola e os jovens, para que seja possível estabelecer um compromisso em se fazer sempre o melhor possível.

Pinsky acredita que o trabalho coletivo em relação à educação seja uma saída possível para superar a crise e, ao mesmo tempo, ensinar cidadania:

Não tenho nenhuma dúvida de que um trabalho de base feito com o envolvimento de professores, alunos, comunidade e governo teria resultados bastante satisfatórios num lapso de tempo curto. A mudança de atitude das pessoas com relação à escola, baseada num sentimento de responsabilidade mútua, poderia constituir o ponto de partida para uma importante virada. Afinal de contas, cidadania é participação, é ter direitos e obrigações, e, ao contrário do que muitos pensam, se aprende na escola". ${ }^{202}$

Como afirmam Corti e Souza, não se trata de não ver os problemas e as dificuldades, mas apesar deles, se lutar pela educação:

Nesse diálogo com a condição juvenil e com os sujeitos jovens, algumas diferenças são inevitáveis, bem como algumas impossibilidades e limites, tanto por parte da escola quanto dos jovens. É importante assumir as diferenças como parte desse processo, e não tentar diluí-las ou escamoteálas. Assim, não cabe aos jovens assumir todas as responsabilidades da escola, nem tampouco cabe à escola tornar-se simplesmente um clube de vivências juvenis. Mas cabe a todos buscar uma aproximação que permita construir uma educação democrática e de qualidade. ${ }^{203}$

Enfim, através de um processo educativo bem elaborado e seguro de seus princípios ideológicos, é possível fazer com que os educandos se formem com qualidade, com compromisso ético, político e social, mesmo em uma sociedade degenerada. Para tanto, é indispensável que haja um trabalho educativo de responsabilidade, que acredite na transformação da sociedade através da educação, como acreditava Rousseau: "Examinem bem a constituição do homem, acompanhem os primeiros desenvolvimentos do coração em tal ou tal circunstância, para ver como um indivíduo pode diferir de outro por força da educação". 204

\footnotetext{
${ }^{202}$ PINSKY, p. 114.

${ }^{203}$ CORTI e SOUZA, p. 140.

${ }^{204}$ ROUSSEAU, Emílio, p. 338.
} 


\section{CONSIDERAÇÕES FINAIS}

O pensamento pedagógico de Rousseau parece ressoar até os dias de hoje, como uma espécie de melodia que leva os ouvintes a uma reflexão profunda e frutífera, despertando um interesse maior por pensar sobre a educação e por ter uma prática pedagógica de qualidade, comprometida com o sucesso dos educandos e com o país.

Embora seja um pensador do século XVIII, suas idéias são bastante atuais, por exemplo, no que diz respeito à sua descrição da sociedade atual, quanto à degeneração moral e política, tratada no Discurso sobre a Origem da Desigualdade, hipótese que, de certo modo, mostra algumas características da sociedade de hoje e, ainda, se observarmos o panorama da educação vigente, podemos notar como os princípios rousseaunianos poderiam nortear a mesma para que houvesse mais comprometimento com a qualidade da educação, como, por exemplo, com a formação de educadores - englobando toda a comunidade escolar - para que trabalhassem tendo como pressupostos os mesmos princípios, para que se privilegiasse a necessidade, a utilidade e a liberdade, por exemplo, dentre outros princípios desenvolvidos no decorrer do Emílio.

E mesmo considerando que alguns autores também abordem essas questões, na maioria das vezes, fazem uma análise sociológica ou histórica dos fatos, sem propor alterações ou pelo menos possibilidades de se pensar uma prática diferente, ou ainda, quando o fazem, parecem desconhecer a realidade do contexto escolar. Rousseau, mesmo estando distante temporalmente da nossa época, apresenta um pensamento que pode ser entendido como uma referência nos dias atuais, pois apresenta problemas e incertezas vivenciados por muitos educadores e, sobretudo, apresenta máximas que podem nortear esses educadores para a resolução desses problemas e o esclarecimento dessas incertezas.

A importância de um vínculo afetivo na relação professor-aluno, isto é, uma relação na qual ambos se respeitem, se admirem e tenham atenção e comprometimento com o processo educativo, é um exemplo de como as idéias do autor podem colaborar com a prática pedagógica atual, pois ao estabelecer a necessidade de que haja um envolvimento ou uma preocupação com o bem-estar das pessoas envolvidas no processo educativo, aponta para o compromisso com uma educação que almeja o bem do educando. Nos dias atuais, esse vínculo enquanto demonstração de preocupação com a qualidade da educação oferecida aos alunos, bem como em relação ao bem-estar dos mesmos é essencial para garantir o sucesso da educação, pois só assim o educador 
consegue afetar o educando para mostrar-lhe a utilidade dos conteúdos e dos valores morais, assim como a necessidade de se ter consciência política para garantir seus direitos e o privilégio das leis.

É evidente que quando se aponta para a possibilidade de utilizar as máximas propostas por Rousseau, não se trata de aplicar o Emílio como se fosse um manual de pedagogia, mesmo porque isso não é possível em relação a nenhuma obra acerca do tema, especialmente por uma característica enfatizada pelo próprio autor: para que o sucesso da educação seja possível, é preciso que o educador conheça a realidade dos seus educandos, bem como desenvolva um plano de ação voltado para essa realidade e para as suas necessidades. Ou seja, não há uma obra que possa ser tomada "ao pé da letra", como uma receita, quando o assunto é a formação de seres humanos, seres tão variáveis, subjetivos e indecifráveis.

Mas se trata de acreditar na educação! Ter certeza de que, através de um trabalho sério e comprometido é possível tornar as coisas diferentes e melhores, o que é a chave da questão; e é, também, a garantia de que se pode amenizar e, quem sabe, a longo prazo, resolver a crise educacional em que o país se encontra.

Não se trata de acreditar cegamente, de ter a fé dos religiosos que normalmente foge à razão, mas de ter uma crença racional, ou melhor, uma convicção fundamentada na razão e condicionada à ação. Acreditar, aqui, significa propriamente, confiar que através da efetivação de um processo educativo de qualidade se pode mudar a realidade atual, possibilitando aos educandos uma formação digna, na qual não somente aprendam aqueles conteúdos disciplinares, mas, sobretudo, aprendam valores morais e tenham consciência política para agirem como verdadeiros cidadãos.

Quando Rousseau parece descrente da possibilidade de se formar o cidadão, logo no início do Emílio, não se trata de desistir do compromisso de uma educação voltada para a política, mas de enfatizar a idéia de que se a pólis não existe mais, é necessário e urgente repensar questões vinculadas à educação pública, pois como o próprio autor afirma "todo homem de bem deve algo, senão à pátria, pelo menos a seu país". ${ }^{205} \mathrm{E}$, ainda, é interessante lembrar que, na concepção rousseauniana, moralidade e política são indissociáveis, ou seja, formar o homem e o cidadão são projetos correlacionados e simultâneos.

${ }^{205}$ Idem, p. 25. 
Portanto, a educação pretendida pelo autor, não se restringe à formação do homem, que tenha bons valores morais para viver bem com sua família ou na vida doméstica, mas abrange a formação do cidadão, que deve ter conhecimento acerca da estrutura e do funcionamento da cidade, bem como de seus direitos e deveres, agindo em concordância com eles, em nome da coletividade.

Em outras palavras, quando propõe uma transformação na educação, por meio do Emílio, embora esteja apontando para o grau máximo da escala e não afirmando que seja algo passível de realização, quer apontar para a necessidade de se formar cidadãos que possam instituir uma espécie de contrato social, formando um corpo político e, conseqüentemente, leis apropriadas e representativas da vontade geral, para que ocorra a verdadeira cidadania.

Considerando que a adolescência é o momento no qual, além do jovem ser inserido na vida social, o processo educativo pode determinar o sucesso de toda formação do jovem: "a parte mais importante e mais difícil de toda a educação, qual seja, a crise que serve de passagem da infância para a condição de homem"206, a transformação proposta pelo autor pretende que, especialmente na adolescência, haja uma inserção social organizada e ele seja bem inserido na vida em sociedade, o que significa ao mesmo tempo, manter os princípios educativos da infância e reforçá-los ou, mais do que isso, jamais abandoná-los para que não se perca a essência de sua educação.

Aliás, essa essência pretendida por Rousseau não deve ser entendida simplesmente pelos exemplos ou situações descritas pelo autor ao longo de suas obras, principalmente do Emílio, mas além delas. Fazendo uso das palavras de Vargas, é preciso considerar os exemplos dados pelo autor como se ele tivesse escrito com uma "tinta invisível ou ilegível", deve-se esquecer as descrições concretas e ter em mente os princípios, ou a essência do seu pensamento pedagógico.

Essa postura reflexiva de leitura para além dos fatos concretos, prioriza o entendimento da essência do pensamento do autor e é o que garante sua atualidade e a apropriação de suas máximas como luz para as práticas pedagógicas de hoje.

Assim, vemos a adolescência descrita por Rousseau como algo muito próximo do que temos hoje e, mais ainda, vemos o quanto seus princípios são necessários na formação desses jovens para que sejam homens de bem e, sobretudo, cidadãos. Por exemplo, os ideais de respeito mútuo, solidariedade, verdade, bom senso, liberdade, utilidade, necessidade, entre outros, são

\footnotetext{
${ }^{206}$ Idem, p. 583.
} 
indispensáveis para que a convivência social seja harmoniosa e para que a associação política se constitua democraticamente.

Os jovens com os quais nos deparamos nas escolas atualmente necessitam de serem olhados, compreendidos, respeitados e considerados importantes, só assim o processo pedagógico se viabiliza para conduzi-los à formação humana - que atualmente não ocorre apenas na educação doméstica - e para a educação pública, condição indispensável para a vida em sociedade. É preciso partir de princípios como esses estabelecidos por Rousseau para se conseguir formar os jovens politicamente, como afirma o autor, esta é "a arte mais necessária ao homem e ao cidadão, que é saber viver com seus semelhantes". ${ }^{207}$

Desse modo, é evidente a necessidade de ter os princípios educativos propostos por Rousseau como um parâmetro fundamental no direcionamento da prática educativa, não como um manual, mas como um aparato útil à reflexão de educadores acerca de sua função. $\mathrm{O}$ papel do educador, na concepção rousseauísta é de extrema importância, posto que pode determinar o sucesso da educação, afinal, é ele quem pode decidir pelos preceitos que orientarão o seu trabalho, enquanto o educando, principalmente nos primeiros anos de formação, fica à mercê dessas escolhas.

Assim, existem pelo menos duas considerações fundamentais acerca da educação dos adolescentes voltada para a cidadania propostas pelo autor. A primeira diz respeito à necessidade de se seguirem as máximas apontadas por ele para o bom desenvolvimento da formação para a vida em sociedade, que pressupõe formação política; a segunda refere-se ao comprometimento dos educadores, com a efetivação dessas máximas como se fossem cláusulas do contrato pedagógico.

Deve-se lembrar que não se trata de fingir que não existem problemas no âmbito escolar, como desvalorização do profissional ou péssimas condições de trabalho, ou na esfera familiar, como a ausência dos pais e a desestrutura familiar, mas de se responsabilizar por uma educação de qualidade apesar dessas questões, assumindo o compromisso de fazer o melhor daquilo que está em nosso alcance.

É preciso ter claro e em mente que o sucesso da educação do adolescente voltada para a cidadania está condicionado à convicção dos educadores de que ela é possível, ao compromisso de se estabelecer princípios claros e seguros como norteadores dessa educação, à efetivação de

\footnotetext{
${ }^{207}$ Ibidem, p. 451.
} 
práticas baseadas nesses princípios e, sobretudo, de se acreditar na eficácia do processo educativo "para ver como um indivíduo pode diferir de outro por força da educação". ${ }^{208}$

${ }^{208}$ Ibidem, p. 338. 


\section{REFERÊNCIAS BIBLIOGRÁFICAS}

\section{A - Obras de Jean-Jacques Rousseau}

ROUSSEAU, Jean-Jacques. Carta a D'Alembert. Tradução de Roberto Leal Ferreira. Campinas: Editora da Unicamp, 1993. (Repertórios)

Considerações sobre o governo da Polônia. In: Obras Políticas. Rio

de Janeiro, Porto Alegre, São Paulo: Editora Globo, 1972.

Da sociedade geral do gênero humano. In: Manuscrito de Genebra. São Paulo: Editora Globo, 1962.

Devaneios do caminhante solitário. Tradução de Fulvia M. L. Moretto.

Brasília: UNB, 1995.

Discurso sobre a Economia Política. Tradução de Maria Constança Peres Pissara. Petrópolis: Vozes, 1996.

Discurso sobre a Origem e os Fundamentos da Desigualdade entre os Homens. Tradução de Lourdes Santos Machado. São Paulo: Abril Cultural, 1973. (Coleção Os Pensadores).

Discurso sobre as Ciências e as Artes. Tradução de Lourdes Santos Machado. São Paulo: Abril Cultural, 1973. (Coleção Os Pensadores).

Do Contrato Social ou Princípios do Direito Político. Tradução de Lourdes Santos Machado. São Paulo: Abril Cultural, 1973. (Coleção Os Pensadores).

Martins Fontes, 1999.

Emílio ou Da Educação. Tradução de Roberto Leal Ferreira. São Paulo:

B - Obras sobre Jean-Jacques Rousseau 
ASSMANN, Selvino José. Sobre a política em Rousseau (É possível ser homem e ser cidadão?). Perspectiva. Florianópolis, v.6, n.11, p. 09-12, Jul/Dez, 1988.

FORTES, Luiz Roberto Salinas Fortes. Paradoxo do Espetáculo: Política e Poética em Rousseau. São Paulo: Discurso/Fapesp, 1997.

Florianópolis, v.6, n.11, p. 13-18, Jul/Dez, 1988.

Fazer o homem ou o cidadão. Perspectiva.

(Prazer em Conhecer)

Rousseau: O bom selvagem. São Paulo: FTD, 1989.

Rousseau: da teoria à prática. São Paulo: Ática, 1976. (Ensaios,

21)

FRANCISCO, Maria de Fátima Simões. Autoridade e contrato pedagógico em Rousseau. In: AQUINO, Júlio Groppa (org.). Autoridade e autonomia na escola: alternativas teóricas e práticas. São Paulo: Summus, 1999.

A primeira lição moral - o episódio das favas no Emílio

de Rousseau. Cadernos de História e Filosofia da Educação, v. II, n.4, p. 35-42, 1998.

NACARATO, Priscila. Ensaios Pedagógicos. São Paulo: Editora Comenius, 2004.

NASCIMENTO, Milton Meira do. Reivindicar direitos segundo Rousseau, In: QUIRINO, Célia Galvão; VOUGA, Cláudio; BRANDÃO, Gildo Marçal (orgs.). Clássicos do Pensamento Político. São Paulo: Edusp/Fapesp, 1998, p. 121-134.

PISSARRA, Maria Constança P. Rousseau: a política como exercício pedagógico. São Paulo: Moderna, 2005.

STAROBINSK, Jean. Jean-Jacques Rousseau: a transparência e o obstáculo. Tradução de Maria Lúcia Machado. São Paulo: Companhia das Letras, 1991.

VARGAS, Yves. Introduction à l'Emile de Rousseau. Paris: PUF, 1995. 
C - Obras sobre Filosofia

ARANHA, Maria Lúcia de Arruda; MARTINS, Maria Helena Pires. Filosofando. Uma introdução à Filosofia. São Paulo: Editora Moderna, 1993.

NASCIMENTO, Milton Meira. Dentro e fora da lei. In: Jornal de Resenhas, nº 91, 09/11/2002.

Ética para todos. In: Jornal de Resenhas, 11/19/2003.

O que são os direitos humanos. In: Folha de São Paulo,

$08 / 07 / 2000$.

D - Obras sobre Educação

CBFC - Centro Brasileiro de Filosofia para Crianças. Filosofia para Crianças - Educação para o Pensar. São Paulo: Cromosete, 2000.

FREIRE, Paulo. Pedagogia da Autonomia. São Paulo: Paz Terra, 1997.

KOHAN, Walter Omar; LEAL, Bernardina (orgs.). Filosofia para crianças em debate. Petrópolis, RJ: Vozes, 1999.

LEAL, Bernardina; KOHAN, Walter Omar; Ribeiro, Álvaro (orgs.). Filosofia na escola pública. Petrópolis: Vozes, 2000.

LIPMAN, Matthew; OSCANYAN, Frederick S.; SHARP, Ann Margareth. A Filosofia na Sala de Aula. São Paulo: Nova Alexandria, 1994.

A Filosofia vai à Escola. São Paulo: Summus, 1990.

O Pensar na Educação. Petrópolis, RJ: Vozes, 1995. 
PINSKY, Jaime. Cidadania e Educação. São Paulo: Contexto, 2001.

TELES, Maria Luiza Silveira. Filosofia para Crianças e Adolescentes. Petrópolis, RJ: Vozes, 1999.

\section{E - Obras Gerais}

ABRAMO, Helena W. e BRANCO, Pedro P. M. (orgs.). Retratos da Juventude Brasileira. São Paulo: Editora Fundação Perseu Abramo, 2005.

BECKER, Daniel. O que é adolescência. São Paulo: Nova Cultural, Brasiliense, 1986.

CORTI, Ana Paula; SOUZA, Raquel. Diálogos com o mundo juvenil: subsídios para educadores. São Paulo: Ação Educativa, 2004.

DIMENSTEIN, Gilberto. O Cidadão de Papel. São Paulo: Editora Ática, 2001.

MAZZUOLI, Valério de Oliveira. Direitos Humanos e Cidadania: à luz do novo direito internacional. Campinas: Minelli, 2002.

Ofício de Professor: aprender mais para ensinar melhor. Programa de Educação à Distância para professores de $5^{\mathrm{a}}$ a $8^{\mathrm{a}}$ e Ensino Médio. São Paulo: Fundação Victor Civita, 2004.

RESENDE, Ênio. Cidadania: o remédio para as doenças culturais brasileiras. São Paulo: Summus, 1992.

REVISTA BRASILEIRA DE EDUCAÇÃO. São Paulo: ANPED, n. 06 e 07, 1997.

SEVERINO, Antonio Joaquim. Metodologia do Trabalho Científico. - $22^{\mathrm{a}}$ edição revista e ampliada. São Paulo: Cortez Editora, 2003. 